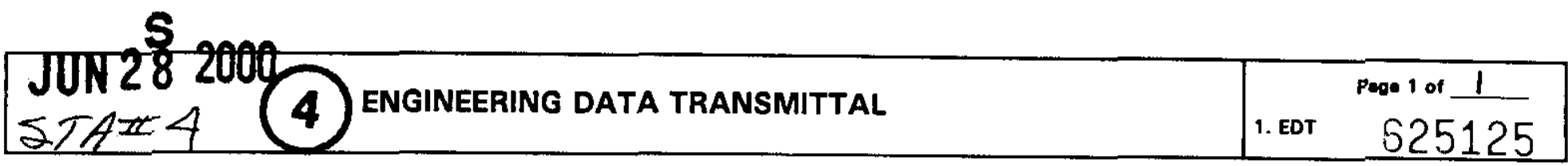

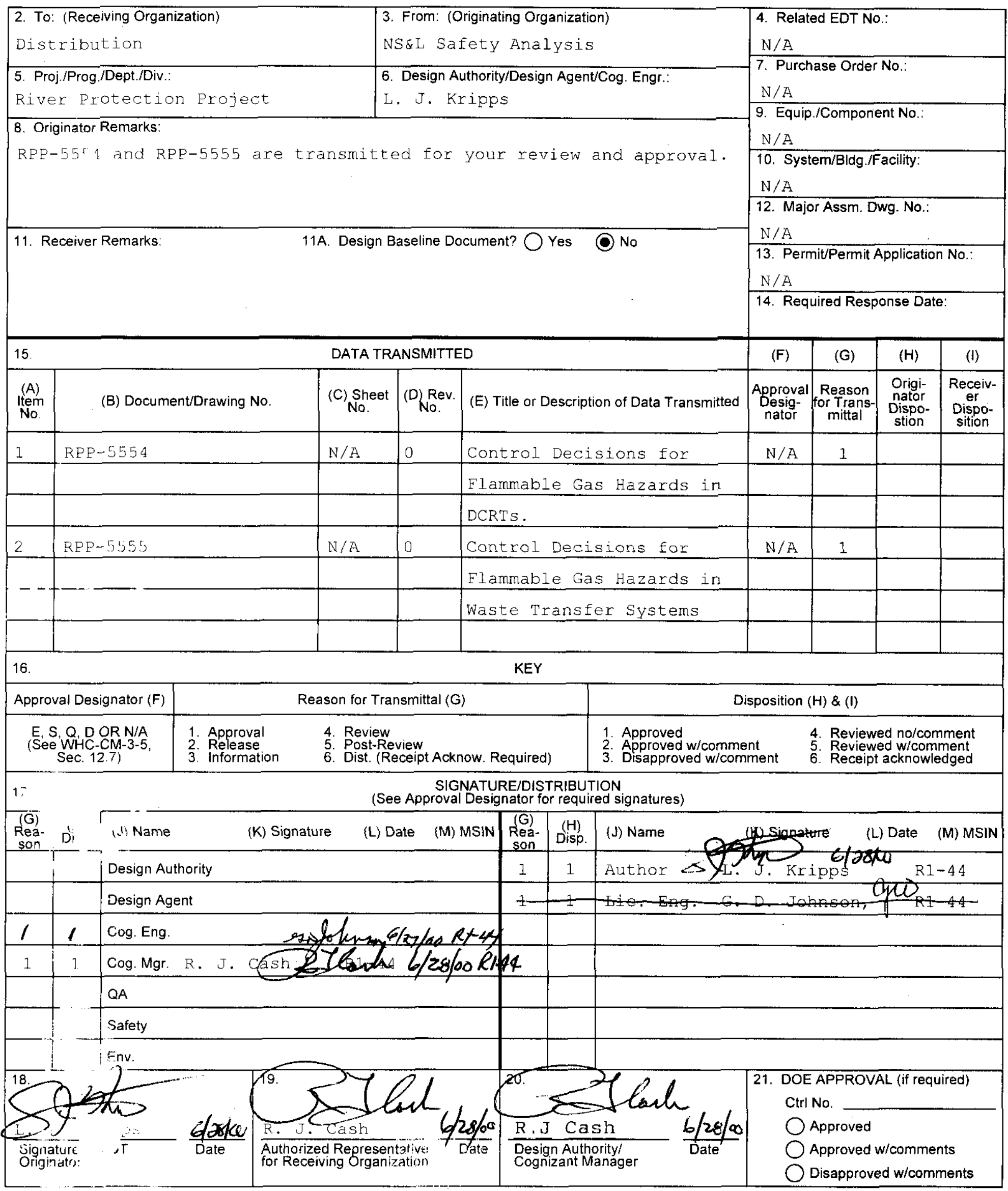




\title{
Control Decisions for Flammable Gas Hazards in Waste Transfer Systems
}

\author{
I. J.Kripps \\ H\&R Technical Associates \\ Richland, WA 99352
}

U.S. Department of Energy Contract DE-AC06-99RL14047
EDT/ECN: 625125
UC: 510
Cost Center: 403
B\&R Code: N/A
Charge Code: 109310
Total Pages: 122

Key Words: controls, control decision record, flammable gas, hazards, safety SSCs, TSRs, transfer systems, waste

Abstract: The document summarizes the results of control decision meetings that were conducted to establish revised controls for flammble gas hazards in waste transfer systems.

TRADEMARK DISCLAIMER. Reference herein to any specific commercial product, process, or service by trade name, trademark, manufacturer, or otherwise, does not necessarlly constitute or imply its endorsement, recommendation, or favoring by the United States Government or any agency thereof or its contractors or subcontractors.

Printed in the United States of America. To obtain copies of this document, contact: Document Control Services, P.O. Box 950, Mailstop H6-08, Richland WA 99352, Phone (509) 372-2420; Fax (509) 376-4989.
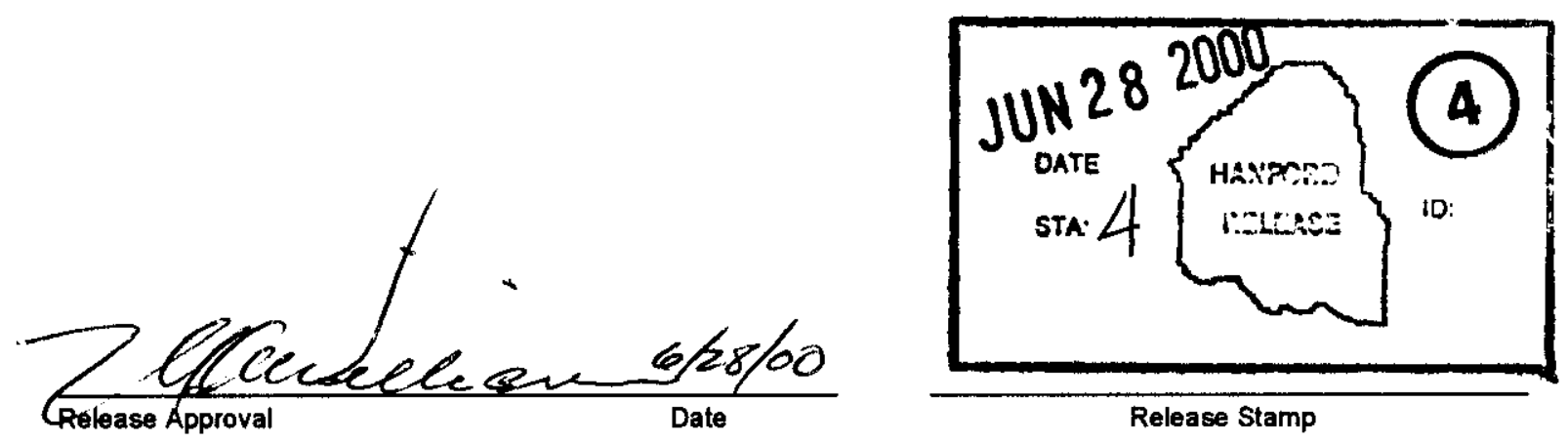

\section{Approved For Public Release}


RPP-5555

Revision 0

\section{Control Decisions for Flammable Gas Hazards in Waste Transfer Systems}

Prepared for the U.S. Department of Energy Assistant Secretary for Environmental Management

\section{CH2MHILL Hanford Group, Inc.}

Richland, Washington

Contractor for the U.S. Department of Energy

Office of River Protection under Contract DE-AC06-99RL14047

Approved for Public Release; Further Dissemination Unlimited 
LEGAL DISCLAMMER

This report was prepared as an account of work sponsored by an agency of the United States Government. Neither the United States Government nor any agency thereof, nor any of their employees, nor any of their contractors, subcontractors or their employees, makes any warranty, express or implied, or assumes any legal liability or responsibility for the

accuracy, completeness, or any third party's use or the results of such use of any information, apparatus, product, or process disclosed, or represents that its use would not infringe privately owned rights. Reference herein to any specific commercial product, process, or service by trade name, trademark, manufacturer, or otherwise, does not necessarily constitute or imply its endorsement, recommendation, or favoring by the United States Government or any agency thereof or its contractors or subcontractors. The views and opinions of authors expressed herein do not necessarily state or reflect those of the United States Government or any agency thereof.

This report has been reproduced from the best available copy. Available in paper copy and microfiche.

Available electronically at http://www.doe.gov/bridge. Available for a processing fee to the U.S. Department of Energy and its contractors, in paper, from:

U.S. Department of Energy

Office of Scientific and Technical Information

P.O. Box 62

Oak Ridge, TN 37831-0062

phone: 865-576-8401

fax: 865-576-5728

email: reports@adonis.osti.gov(423) 576-8401

Available for sale to the public, in paper, from:

U.S. Department of Commerce

National Technical Information Service

5285 Port Royal Road

Springfield, VA 22161

Phone: 800-553-6847

fax: 703-605-6900

email: orders@ ntis.fedworld.gov

online ordering:

http://www.ntis.gov/ordering.htm 
RPP-5555

Revision 0

\section{Control Decisions for Flammable Gas Hazards in Waste Transfer Systems}

L. J. Kripps

H\&R Technical Associates

Date Published

June 2000

Prepared for the U.S. Department of Energy

Assistant Secretary for Environmental Management

\section{CH2MHILL \\ Hanford Group, Inc.}

P. O. Box 1500

Richland, Washington

Contractor for the U.S. Department of Energy

Office of River Protection under Contract DE-AC06-99RL14047

Approved for Public Release; Further Dissemination Unlimited 


\section{CONTENTS}

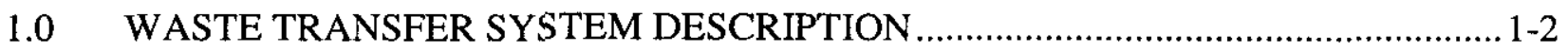

2.0 POTENTIAL FLAMMABLE GAS HAZARDOUS CONDITIONS .............................2-1

2.1 WASTE TRANSFER PIPING ..................................................................

2.2 WASTE TRANSFER-ASSOCIATED STRUCTURES ……........................... 2-2

3.0 RISK OF POSTULATED FLAMMABLE GAS ACCIDENTS .................................... 3-1

3.1 WASTE TRANSFER PIPING ...................................................................

3.2 WASTE TRANSFER-ASSOCIATED STRUCTURES ………........................ $3-1$

4.0 EXISTING AND POSSIBLE FLAMMABLE GAS CONTROLS …........................... 4-1

4.1 WASTE TRANSFER PIPING ................................................................

4.2 WASTE TRANSFER-ASSOCIATED STRUCTURES ................................... $4-2$

4.2.1 Possible Ventilation Controls ............................................................... 4-2

4.2.2 Possible Ignition Source Controls ............................................................. 4-2

4.2.3 Possible Flammable Gas Monitoring Controls .........................................4-3

4.2.4 Possible Other Controls.............................................................................. 4-3

5.0 CONTROL DECISIONS .................................................................................

5.1 WASTE TRANSFER PIPING ................................................................

5.2 WASTE TRANSFER-ASSOCIATED STRUCTURES ..................................5-1

5.2.1 Existing Controls............................................................................... 5-1

5.2.2 Controls to Prohibit Sealing Waste Transfer-Associated Structures ....... 5-2

5.2.3 Ignition Source Controls ........................................................................ 5-3

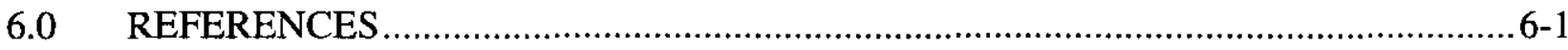

\section{APPENDICES}

A CONTROL DECISION RECORD FOR FLAMMABLE GAS HAZARDS IN WASTE TRANSFER PIPING.

B CONTROL DECISION RECORD FOR FLAMMABLE GAS HAZARDS IN WASTE TRANSFER-ASSOCIATED STRUCTURES

C ASSESSMENT OF THE CONSEQUENCES OF FLAMMABLE GAS DEFLAGRATIONS IN RCSTS DIVERSION BOX 6241-A AND VENT STATION 6241-V. 
RPP-5555 REV 0

ATTACHMENTS

1 AGENDA FOR CONTROL DECISION MEETINGS ON NOVEMBER 30 AND DECEMBER 1, 1999 TO ADDRESS WASTE TRANSFER SYSTEM FLAMMABLE GAS HAZARDS

2 ATTENDANCE LIST FOR THE CONTROL DECISION MEETING ON NOVEMBER 30, 1999 TO ADDRESS WASTE TRANSFER SYSTEM FLAMMABLE GAS HAZARDS Att 2-i

3 PURPOSE, SCOPE, AND PROCESS FOR THE CONTROL DECISION MEETINGS TO ADDRESS WASTE TRANSFER SYSTEM FLAMMABLE GAS HAZARDS Att 3-i

4 CONTROL DECISION MEETING PRESENTATIONS Att 4-i

5 CONTROL DECISION MEETING ON APRIL 19, 2000 TO ADDRESS FLAMMABLE GAS HAZARDS IN DCRTS AND WASTE TRANSFER SYSTEMS Att 5-i

\section{FIGURES}

Figure 1-1. Typical Waste Transfer Line Concrete and Pipe-in-Pipe Encasement Configurations. $1-3$

Figure 1-2. Typical Valve Pit..................................................................................... 1-4

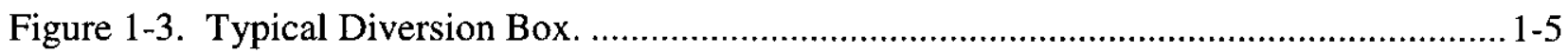

\section{TABLES}

Table 2-1. Potential Flammable Gas Hazardous Conditions in Waste Transfer-Associated Structures with Significant Consequences to Onsite Workers (S2) and the Offsite Public (S3)

Table 3-1. Consequences of Flammable Gas Deflagrations/Detonations in Waste Transfer-Associated Structures (Without Controls). 


\section{RPP-5555 REV 0}

\section{LIST OF TERMS}

DCRT

DOE

DST

FSAR

LFL

ORP

RCSTS

SSC

SST

TSR

USQ double-contained receiver tank

U.S. Department of Energy

double-shell tank

Final Safety Analysis Report

lower flammability limit

Office of River Protection

replacement cross-site transfer system

structure, system, and component

single-shell tank

Technical Safety Requirement

Unreviewed Safety Question 
RPP-5555 REV 0

This page intentionally left blank. 


\section{CONTROL DECISIONS FOR FLAMMABLE GAS HAZARDS IN WASTE TRANSFER SYSTEMS}

This report describes the control decisions for flammable gas hazards in waste transfer systems (i.e., waste transfer piping and waste transfer-associated structures) made at control decision meetings on November 30,1999 and April 19,2000, and their basis. These control decisions, and the analyses that support them, will be documented in an amendment to the Final Safety Analysis Report (FSAR) (CHG 2000a) and Technical Safety Requirements (TSR) (CHG 2000b) to close the Flammable Gas Unreviewed Safety Question (USQ) (Bacon 1996 and Wagoner 1996). Following the Contractor Tier I review of the FSAR and TSR amendment, it will be submitted to the U.S. Department of Energy (DOE), Office of River Protection (ORP) for review and approval.

The control decision meeting on November 30, 1999 to address flammable gas hazards in waste transfer systems followed the control decision process and the criteria for control decisions described in Section 3.3.1.5 of the FSAR. The control decision meeting agenda, attendance list, and introductory and background presentations are included in Attachments 1 through 4. The control decision discussions on existing and other possible controls for flammable gas hazards in waste transfer systems and the basis for selecting or not selecting specific controls are summarized in this report.

The agenda, attendance list, and the purpose, scope, and process for the April 19, 2000 control decision meeting, and the presentations at that meeting related to flammable gas hazards in waste transfer systems are included in Attachment 5. The only discussion on controls for waste transfer system flammable gas hazards involved a new assessment of postulated flammable gas deflagration accidents in Replacement Cross-Site Transfer System (RCSTS) diversion box $6241-\mathrm{A}$ and vent station $6241-\mathrm{V}$. These control decision discussions are also summarized in this report.

Waste transfer systems included in the scope of the control decision meetings are described in Section 1.0. Sections 2.0 and 3.0 summarize the hazard and accident analyses of flammable gas hazards in waste transfer systems that supported the control decisions. Existing and possible controls that were considered to prevent or mitigate waste transfer system flammable gas hazards are identified in Section 4.0. Section 5.0 summarizes the control decisions and the basis for the selected controls.

\footnotetext{
${ }^{a}$ Control decision meetings for flammable gas hazards in waste transfer systems were originally scheduled for November 30 and December 1, 1999, but were completed in one day (i.e., November 30, 1999).
} 


\subsection{WASTE TRANSFER SYSTEM DESCRIPTION}

Waste transfer systems include waste transfer piping and waste transfer-associated structures as well as related equipment such as jumpers, valves, and pumps. The waste transfer systems transfer liquid waste to and from tank farm storage and related facilities (e.g., double-contained receiver tanks [DCRTs], catch tanks, vaults). Liquid wastes are also received from other facilities (e.g., the Plutonium Finishing Facility, 222-S Laboratory) and transferred to and from the 242-A Evaporator by the waste transfer systems.

Waste transfer piping includes unencased (single wall, direct buried or bermed) lines, concrete encased lines, and pipe-in-pipe encased lines (see Figure 1-1). The waste transfer system consists of a network of underground and temporary overground transfer lines. Active and known inactive transfer lines are listed in Tables 2-22 and 2-23, respectively, of the FSAR.

Waste transfer-associated structures are typically below grade concrete enclosures with removable concrete or steel covers. They provide access from the surface to waste transfer piping and tank risers, and are the locations where jumpers, valves, pumps, etc. are installed to establish waste transfer routes. Waste transfer-associated structures include process pits (e.g., pump pits, sluice pits), valve pits, diversion boxes, cleanout boxes, etc. (see FSAR Table 4-4. ${ }^{b}$ Figures 1-2 and 1-3 show several typical waste transfer-associated structures. While a small number of waste transfer-associated structures are passively ventilated through high-efficiency particulate air filters (e.g., RCSTS diversion box 6241-A and vent station $6241-\mathrm{V})$, ventilation flow rates for most waste transfer-associated structures are uncertain and sometimes restricted (e.g., duct tape, polyurethane foam) to prevent the inleakage of water or to establish desired ventilation system flows.

Additional design information on waste transfer systems is contained in Section 2.4 and Addendum 2 of the FSAR.

\footnotetext{
${ }^{b}$ The control decision scope includes all waste transfer-associated structures (active and inactive). However, as discussed in Section 2.0, the control decision scope does not include flammable gas hazards caused by flammable gases that enter waste transfer-associated structures from the headspace of a directly connected tank (i.e., single-shell tanks, double-shell tanks, double-contained receiver tanks, and catch tanks). Controls for these flammable gases hazards are addressed as part of the flammable gas controls for the connected tank.
} 


\section{RPP-5555 REV 0}

Figure 1-1. Typical Waste Transfer Line Concrete and Pipe-in-Pipe Encasement Configurations.
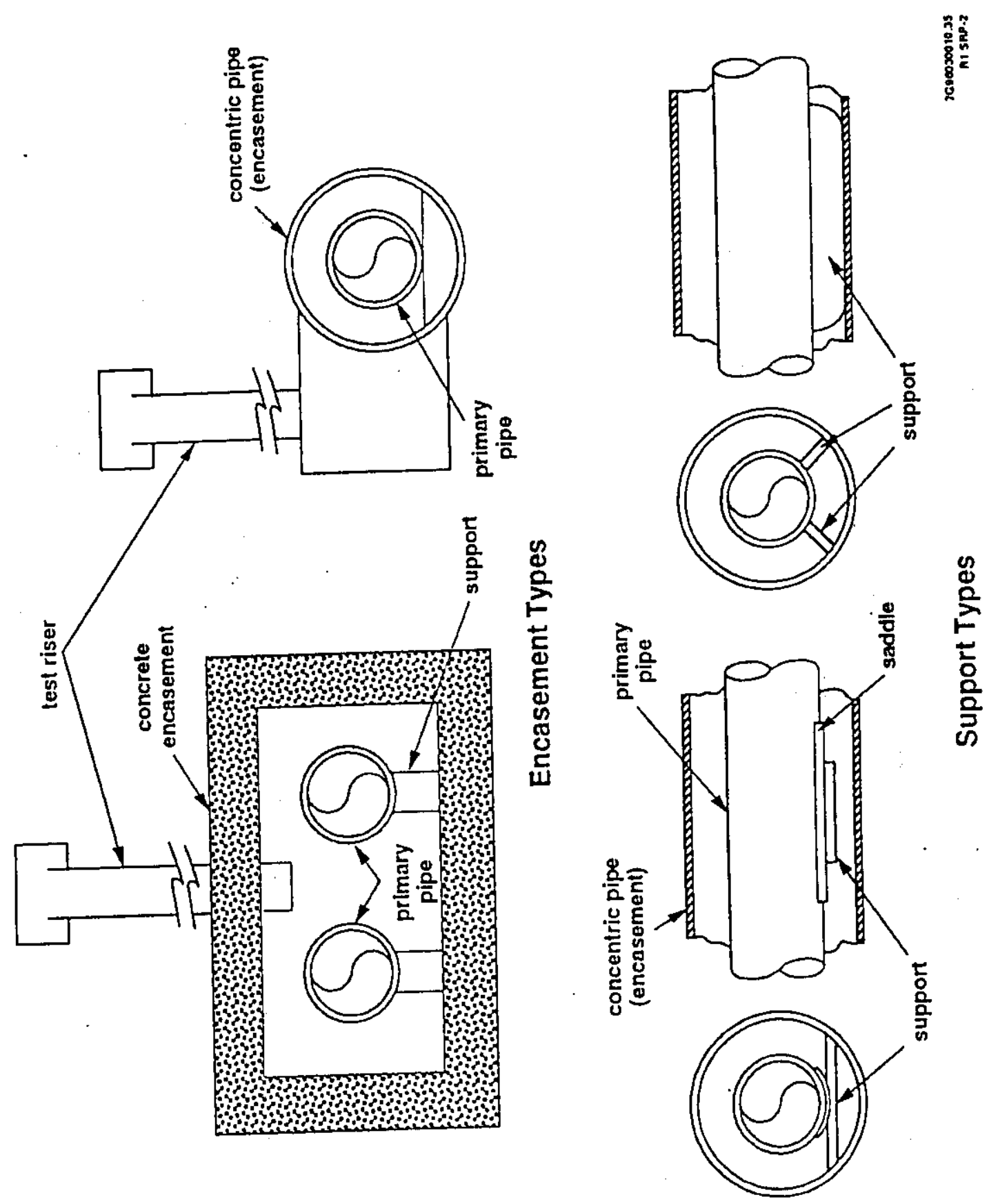
Figure 1-2. Typical Valve Pit.

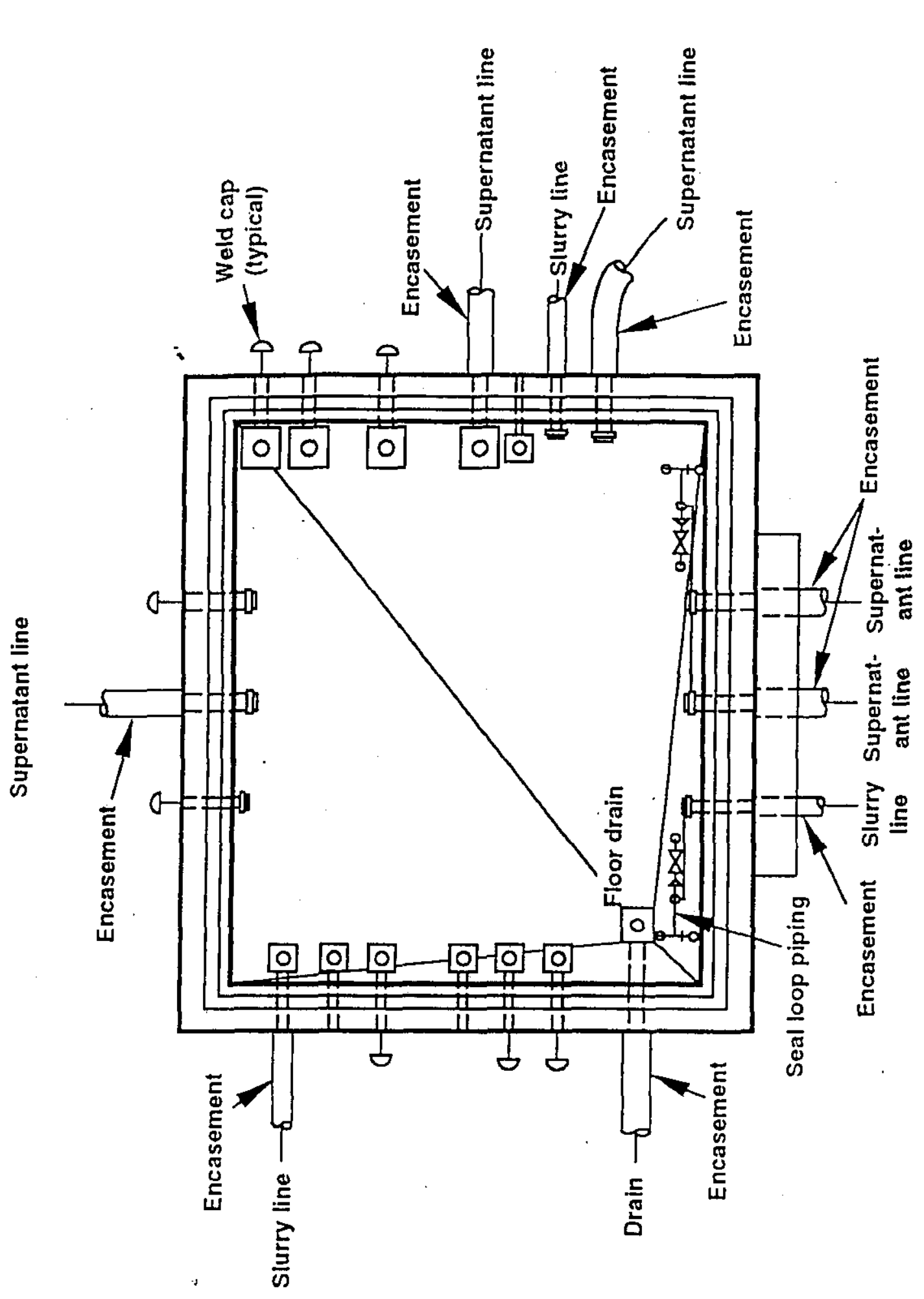




\section{RPP-5555 REV 0}

Figure 1-3. Typical Diversion Box.

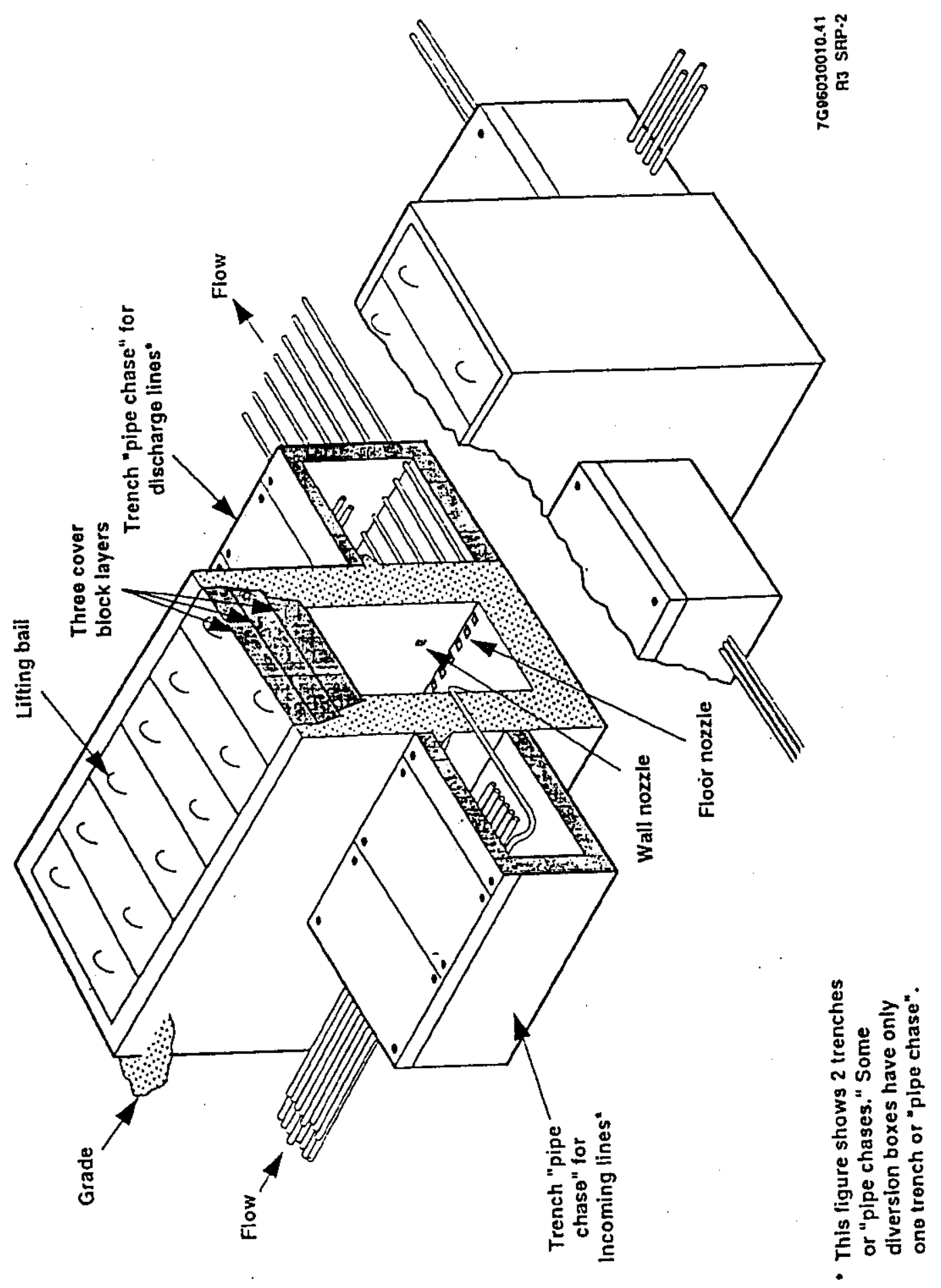




\section{RPP-5555 REV 0}

This page intentionally left blank. 
RPP-5555 REV 0

\subsection{POTENTIAL FLAMMABLE GAS HAZARDOUS CONDITIONS}

Potential flammable gas hazardous conditions in waste transfer piping and waste transfer-associated structures are described in the following sections based on the results of new and existing hazard analyses.

\subsection{WASTE TRANSFER PIPING}

Flammable gas hazards in waste transfer piping result from the steady-state (or chronic) accumulation of flammable gases (e.g., hydrogen, ammonia, methane). In primary piping, flammable gases (1) can be transferred in with the waste (e.g., soluble gases, gas bubbles); (2) can be produced from waste in the primary piping by radiolysis of water and organics, chemical reactions (or thermolysis), and corrosion processes (LMHC 1999); and (3) can enter the primary piping if it is open to a flammable gas environment in a tank or waste transfer-associated structure or if it is submerged in tank waste. Flammable gas hazards in piping encasements result primarily from primary piping leaks, but they can also result if the piping encasement is open to a tank or waste transfer-associated structure where a flammable gas environment exists. An ignition source is also required for a flammable gas deflagration or detonation. ${ }^{\mathrm{c}}$ [Note: An oxidizer (e.g., oxygen) is additionally required and is assumed to be present.]

The results of a new hazard analysis of waste transfer system flammable gas hazards [HNF-5334, Hazard Evaluation for Waste Transfer System Piping Flammable Gas Hazards (FDNW 1999)] was presented and reviewed at the November 30, 1999 control decision meeting. The hazard analysis identified no potential flammable gas hazardous conditions for waste transfer piping with significant offsite (public) consequences (S3), significant onsite worker consequences (S2), or significant facility worker consequences with an uncontrolled frequency of anticipated (i.e., $10^{-2}$ to $10^{0}$ per year) (S1, F3). The following are key observations from this hazard analysis that were supported by the calculations contained in HNF-2251, Calculation Note on Flammable Gas in Waste Transfer Lines (FDNW 1998).

- During waste transfers, except for salt well pumping, there is no headspace in the primary piping for flammable gases to accumulate. (See HNF-2251, Section 7.0.)

- During salt well pumping, and when flammable gases could accumulate in primary piping if it became plugged or was not flushed following a transfer, the material at risk is small.

- There are existing controls to detect primary piping leaks that could result in the accumulation of flammable gases in piping encasements, and the material at risk in piping encasements is small.

\footnotetext{
c Special conditions (e.g., higher flammable gas concentrations, geometry) are required for flammable gas detonations making them less likely than deflagrations.
} 


\section{RPP-5555 REV 0}

- Flammable gas accumulation to concentrations that exceed the lower flammability limit (LFL) in primary piping and piping encasements is slow (days to weeks). (See HNF-2251, Sections 5.2.1 and 5.2.2.)

- Flammable gas ignition sources in waste transfer piping are very limited, and those that exist are already controlled (i.e., excavation controls, vehicle restrictions or concrete shielding systems surrounding overground transfer lines). Encasement leak detection systems are potential ignition sources in piping encasements.

- The direct consequences of a flammable gas deflagration or detonation in waste transfer piping is mitigated by the inherent strength of the primary piping and piping encasements and by the soil that covers buried or bermed waste transfer piping. (See HNF-2251, Sections 2.0 and 3.0.)

- Flammable gas deflagrations or detonations in waste transfer piping are potential initiators of waste leaks accidents (i.e., spray leaks or leaks resulting in a surface pool). Waste leak accidents are, however, prevented or mitigated by existing controls that are independent of the specific accident initiator, and these controls are not expected to be affected by a waste transfer piping deflagration or detonation. (See HNF-2251, Section 4.0.)

Subsequent to the November 30, 1999 control decision meeting, an electronic search of the existing Authorization Basis hazard analysis database was performed. The results showed that potential waste transfer piping flammable gas hazardous conditions in the existing hazard analysis database were addressed in HNF-5334 with two exceptions. The exceptions were postulated scenarios where a flammable gas deflagration propagated from a DCRT to a single-shell tank (SST) through a waste transfer line, and where a flammable gas deflagration in a waste transfer line initiated a deflagration in an SST or double-shell tank (DST). The consequences of these potential hazardous conditions are dominated by the flammable gas deflagration in the DST, SST, and/or DCRT, and the controls are the flammable gas controls for DSTs, SSTs, and DCRTs. These potential hazardous conditions are, therefore, outside the scope of the November 30,1999 and April 19, 2000 control decision meetings.

\subsection{WASTE TRANSFER-ASSOCIATED STRUCTURES}

Flammable gas hazards in waste transfer-associated structures result from the steady-state (or chronic) accumulation of flammable gases (e.g., hydrogen, ammonia, methane). Flammable gases can be produced from waste that leaks into the waste transfer-associated structure or can enter through waste transfer piping, drain lines, or risers that are open to the waste transfer-associated structure. The scope of control decisions at the November 30, 1999 and April 19, 2000 meetings and this report do not address flammable gas hazards caused by flammable gases entering waste transfer-associated structures from directly connected tanks (i.e., SSTs, DSTs, DCRTs, and catch tanks). Controls for these flammable gases hazards are addressed by the flammable gas controls for the connected tank. 
The results of the new hazard analysis of waste transfer-associated structures (HNF-5334) identified six (6) potential flammable gas hazardous conditions with significant onsite worker consequences (S2) (see Table 2-1). No hazardous conditions were identified with potential for significant offsite (public) consequences (S3) or significant facility worker consequences with an uncontrolled frequency of anticipated (S1, F3).

Subsequent to the November 30, 1999 control decision meeting, an electronic search of the Authorization Basis hazard analysis database was performed to identify existing potential flammable gas hazardous conditions in waste transfer-associated structures. This search yielded the following results which must be considered in conjunction with the HNF-5334 hazard analysis results.

- Flammable gas deflagrations in the RCSTS diversion box 6241-A and vent station 6241-V were binned under the "Flammable Gas Deflagrations - SST" representative accident because of the size of these waste transfer-associated structures, versus the "Fire in Contaminated Area" representative accident where all other potential flammable gas deflagrations in waste transfer-associated structures were binned. In addition, a flammable gas deflagration in the RCSTS diversion box 6241-A was qualitatively determined to have the potential for significant offsite public consequences (S3).

- Flammable gas deflagrations in waste transfer-associated structures could initiate waste leak accidents (i.e., spray leaks or leaks resulting in a surface pool) by lifting transfer system cover blocks and their falling onto waste transfer piping. Spray releases and surface pools have the potential for significant offsite (public) consequences (S3).

- Flammable gas deflagrations in waste transfer-associated structures could initiate an unfiltered release from an SST or DST with the potential for significant facility worker consequences with an uncontrolled frequency of anticipated (S1, F3). 
RPP-5555 REV 0

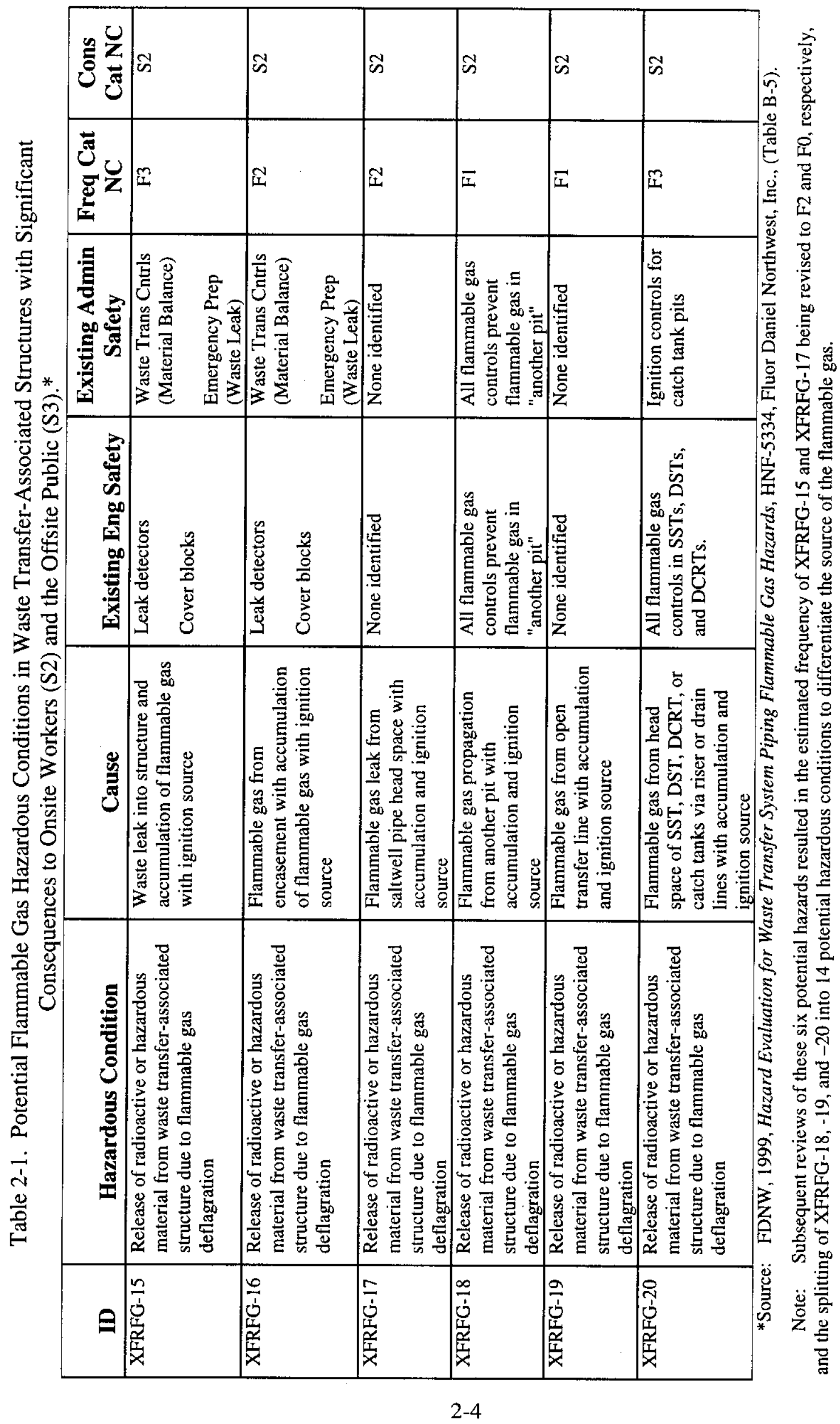




\subsection{RISK OF POSTULATED FLAMMABLE GAS ACCIDENTS}

The frequency and consequences (i.e., risk) of postulated flammable gas deflagration or detonation accidents in waste transfer piping and waste transfer-associated structures are discussed in the following sections.

\subsection{WASTE TRANSFER PIPING}

Postulated flammable gas accidents in waste transfer piping, when possible, are unlikely ( $10^{-4}$ to $10^{-2}$ per year) (see Section 2.1). The direct effects of a postulated flammable gas deflagration or detonation in waste transfer piping have only the potential for significant facility worker consequences (see Section 2.1). Waste transfer piping flammable gas deflagrations and detonations can, however, initiate waste transfer system leak accidents and flammable gas deflagration accidents in waste storage tanks (e.g., DSTs, SSTs) that have significant offsite (public) and onsite worker consequences ( $\mathrm{S} 3$ or S2). The consequences of these accidents are represented by the representative accidents analyzed in the following FSAR sections.

- Section 3.3.2.4.7 - Subsurface Leak Remaining Subsurface

- Section 3.4.2.2 - Flammable Gas Deflagration

- Section 3.4.2.7 - Surface Leak Resulting in Pool

- Section 3.4.2.8 - Subsurface Leak Resulting in a Pool

- Section 3.4.2.9 - Spray Leak in Structure or From Waste Transfer Lines.

\subsection{WASTE TRANSFER-ASSOCIATED STRUCTURES}

The postulated accident scenario in waste transfer-associated structures is the accumulation of flammable gases to a concentration above the LFL. An ignition source then causes a deflagration or detonation. The estimated frequency of this postulated accident scenario is unlikely, except when caused by flammable gases entering from a directly connected tank. For these accident scenarios the estimated frequency is anticipated.

For most waste transfer-associated structures, the direct consequences of a flammable gas deflagration are bounded by the FSAR representative accident Fire in Contaminated Area (see FSAR Section 3.3.2.4.3). This is confirmed by calculations in HNF-2251 (Section 6.0), which are compared to the consequences of the Fire in Contaminated Area accident in Table 3-1. 
RPP-5555 REV 0

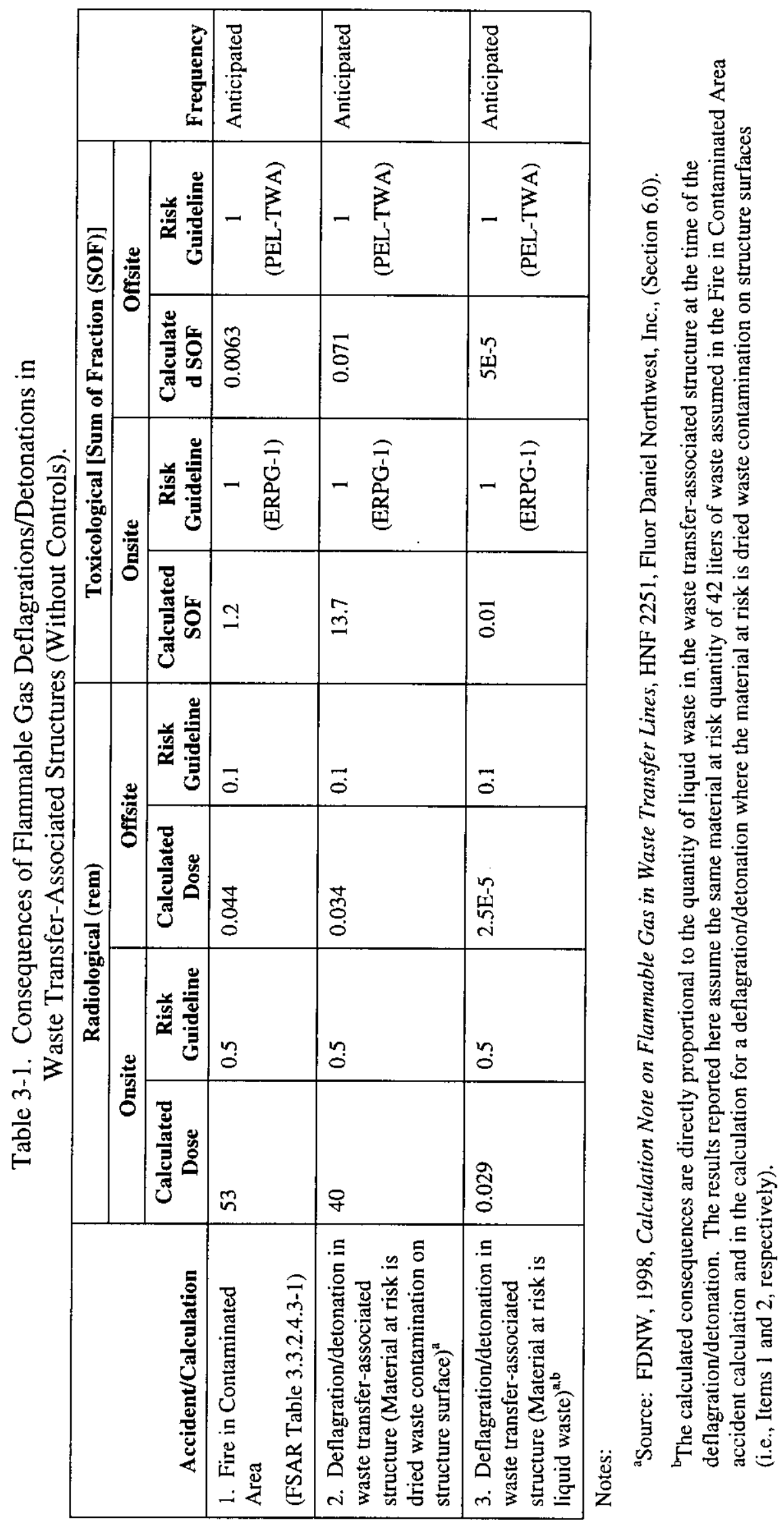


An assessment of the potential consequences from a flammable gas deflagration caused by a waste leak in the large RCSTS diversion box 6241-A or vent station 6241-V was provided at the April 19, 2000 control decision meeting (see Attachment 5-Part 4 and Appendix 3). This assessment concluded that the potential consequences of flammable gas deflagrations in these structures are well below the offsite radiological and toxicological risk guidelines and, therefore, have the potential for only significant onsite facility workers impacts (S2).

Waste transfer-associated structure flammable gas deflagrations or detonations can also initiate waste transfer system leak accidents and flammable gas deflagrations in waste storage tanks (e.g., DSTs, SSTs). The consequences of these accidents are represented by representative accidents analyzed in following FSAR sections.

- Section 3.4.2.2 - Flammable Gas Deflagration

- Section 3.4.2.7 - Surface Leak Resulting in Pool

- Section 3.4.2.9 - Spray Leak in Structure or From Waste Transfer Lines.

It is important to note that in addition to initiating a waste leak, a deflagration or detonation in a waste transfer-associated structure may also defeat the safety function of the transfer system covers. 
RPP-5555 REV 0

This page intentionally left blank. 


\subsection{EXISTING AND POSSIBLE FLAMMABLE GAS CONTROLS}

Existing controls and other possible controls that could prevent or mitigate flammable gas hazards in waste transfer piping and waste transfer-associated structures identified and considered at the November 30, 1999 control decision meeting are presented in the following sections. No new controls were considered at the April 19,2000 control decision meeting.

\subsection{WASTE TRANSFER PIPING}

There are no existing safety structure, system, or component (SSC) or TSR controls that specifically address the risk of flammable gas hazards in waste transfer piping. There is one defense-in-depth control to flush waste transfer piping after use to reduce the risk of flammable gas generation and accumulation in the piping. There are, however, existing controls selected to prevent or mitigate other potential hazardous conditions or postulated accidents that also serve to reduce the risk of flammable gas hazards in waste transfer piping. These other existing controls include the following.

- Excavation controls detailed in Hanford Site procedures and the control in TSR AC 5.12.2.a (fifth bullet) that requires vehicle restrictions or concrete shielding systems surrounding overground transfer lines, prevent these specific ignition sources in waste transfer piping.

- Safety SSCs (e.g., piping encasements, transfer leak detection systems) and TSRs (e.g., LCO 3.1.3, AC 5.12, AC 5.13) that provide for the detection of waste leaks from primary piping into piping encasements.

Note: There was discussion at the November 30, 1999 control decision meeting on whether Ignition Source Control Set 2 applies to activity-related equipment and materials until work activity entry monitoring requirements are met for waste transfer piping (i.e., TSR AC 5.10, Table 5.10-1; and TSR AC 5.11, Table 5.11-1). The consensus was that these TSR controls do not apply to waste transfer piping for two reasons.

1. There are problems with implementing these controls for waste transfer piping (e.g., no access for flammable gas monitoring prior to entry into closed piping).

2. TSR level controls are not required for this hazard (i.e., the hazard affects only facility workers and is unlikely).

There was consensus that flammable gas hazards in waste transfer piping should be addressed by the hazardous material protection program (e.g., HASP, industrial safety). This program is one of the required safety management programs listed in TSR AC 5.24.

Other possible controls for flammable gas hazards in waste transfer piping identified at the November 30, 1999 control decision meeting were requiring that encasement leak detectors meet TSR AC 5.10 Ignition Source Control Set 2 requirements and design modifications that would 
eliminate the headspace in waste transfer system primary piping during salt well transfers (e.g., flow restrictors, elevated piping at receiver tank). The latter control was immediately eliminated due to its impracticality and cost.

\subsection{WASTE TRANSFER-ASSOCIATED STRUCTURES}

Existing controls for flammable gas hazards in waste transfer-associated structures include the following.

- Ignition Source Control Set 2 applies to activity-related equipment and materials until work activity entry monitoring requirements are met for waste transfer-associated structures (i.e., TSR AC 5.10, Table 5.10-1; and TSR AC 5.11, Table 5.11-1).

- Safety SSCs (e.g., transfer leak detection systems) and TSRs (e.g., LCO 3.1.3, AC 5.12) that prevent or detect waste leaks or mistransfers into waste transfer-associated structures. (Note: Since waste transfer system leaks or mistransfers are the primary cause of flammable gas hazards in waste transfer-associated structures, these controls also address this hazard.)

- Emergency response plans that require consideration of ignition controls for waste leaks (or mistransfers) into waste transfer-associated structures because of the possibility of unfavorable flammable gas conditions within the structure (TSR AC 5.14.2.d).

Other possible controls for flammable gas hazards in waste transfer-associated structures identified at the November 30, 1999 control decision meeting are listed below.

\subsubsection{Possible Ventilation Controls}

1. Prohibit sealing of waste transfer-associated structures.

2. Design modifications to provide passive ventilation for waste transfer-associated structures.

3. Design modifications to provide active ventilation for waste transfer-associated structures.

4. Design modifications to provide a system to inert waste transfer-associated structures.

\subsubsection{Possible Ignition Source Controls}

1. Apply Ignition Source Control Set 2 requirements to all equipment installed in waste transfer-associated structures.

2. Require transfer leak detection systems in waste transfer-associated structures to meet Ignition Source Control Set 2 requirements. 


\section{RPP-5555 REV 0}

\subsubsection{Possible Flammable Gas Monitoring Controls}

1. Establish requirements for periodic flammable gas monitoring of waste transfer-associated structures. (Note: This would likely require design modifications to install sample probes and connections.)

2. Design modifications to provide continuous monitoring of waste transfer-associated structures.

\subsubsection{Possible Other Controls}

1. Design modifications to ensure that transfer system covers perform their safety functions following flammable gas deflagrations/detonations in waste transfer-associated structures (e.g., relief valves, transfer system cover guides).

Of the above possible controls, only the possible controls prohibiting the sealing of waste transfer-associated structures and applying Ignition Source Control Set 2 to equipment in waste transfer-associated structures were considered (see Section 5.2). The impracticality and cost of the other possible controls eliminated them from further consideration. 


\section{RPP-5555 REV 0}

This page intentionally left blank. 


\subsection{CONTROL DECISIONS}

Appendices $\mathrm{A}$ and $\mathrm{B}$ are the control decision records documenting the controls selected to prevent or mitigate flammable gas hazards in waste transfer piping and waste transfer-associated structures, respectively, at the November 30, 1999 control decision meeting. Discussions that led to these control decisions are summarized in the following sections. The control decision meeting on April 19, 2000 resulted in no control revisions. However, based on the new assessment of potential consequences of flammable gas deflagrations in RCTST diversion box 6241-A and vent station $6241-\mathrm{V}$, there was consensus that safety SSCs that detect waste leaks or mistransfers into waste transfer-associated structures (e.g., transfer leak detection systems) are safety-significant.

\subsection{WASTE TRANSFER PIPING}

The consensus was that no controls (i.e., no safety SSCs or TSRs) are required for flammable gas hazards in waste transfer piping. This was based on the results of the hazard and accident analyses that showed the direct effects of a flammable gas deflagration or detonation in waste transfer piping would have no significant consequences to the offsite public or onsite workers, and no significant anticipated consequences to facility workers. Appendix A, therefore, simply lists existing controls considered as defense-in-depth for flammable gas hazards in waste transfer piping.

Note: As discussed in Sections 2.1 and 3.1, flammable gas deflagrations in waste transfer piping could initiate waste leaks (i.e., spray leaks or leaks resulting in a surface pool) with the potential for significant offsite public or onsite worker consequences. Waste leak accidents are, however, prevented or mitigated by existing controls that are independent of the specific accident initiator, and these controls are not expected to be affected by the waste transfer piping deflagration or detonation (see HNF-2251).

\subsection{WASTE TRANSFER-ASSOCIATED STRUCTURES}

The control decision discussions addressing flammable gas hazards in waste transfer-associated structures focused on existing controls and two other possible controls. These discussions are summarized in this section.

\subsubsection{Existing Controls}

By consensus the primary controls selected to address flammable gas hazards in waste transfer-associated structures were existing controls that prevent or detect waste leaks or mistransfers into waste transfer-associated structures in conjunction with existing emergency preparedness controls that require actions in response to possible unfavorable flammable gas conditions following waste leaks into waste transfer-associated structures. [Note: Time to LFL calculations in HNF-2251 (Section 5.2.3.1) show that waste transfer-associated structures would have to be more than one-third full of waste to reach the LFL and even then it would require 
several weeks to reach the LFL assuming only barometric breathing (i.e., an average air exchange rate of $0.46 \%$ of the structure volume/day) (WHC-EP-0651, Barometric Pressure Variations [WHC 1993]). Additional ventilation flow due to other natural causes, such as wind and temperature changes, and diffusion of hydrogen through concrete were conservatively ignored.] Existing controls also include ignition and flammable gas monitoring requirements for manned entry into waste transfer-associated structures.

It was recognized during the control decision discussions that flammable gas deflagrations or detonations in waste transfer-associated structures could not only initiate waste leaks (i.e., spray leaks or leaks resulting in a surface pool), but could also defeat the safety function of the transfer system covers. The existing controls, however, prevent flammable gas deflagrations or detonations in waste transfer-associated structures and, therefore, prevent this postulated waste leak accident scenario.

\subsubsection{Controls to Prohibit Sealing Waste Transfer-Associated Structures}

There was considerable discussion on a possible control to prohibit sealing of waste transfer-associated structures. With respect to this possible control, the following consensus was reached.

- A control to prevent the "sealing" of waste transfer-associated structures is needed. [Note: "Sealing" here means to reduce the ventilation flow below barometric breathing (i.e., an average air exchange rate of $0.46 \%$ of the structure volume/day).]

- An extensive/expensive program to verify that all active and inactive waste transfer-associated structures are either not "sealed" or have no ignition sources (i.e., equipment meets Ignition Source Control Set 1 or is removed or deenergized) is not required.

- Any control to prevent the "sealing" of waste transfer-associated structures should only apply to future design changes and operations actions.

Based on the above, the following control was drafted.

\section{New Program Key Element 5.9.2c}

c. Waste Transfer-Associated Structure Ventilation Control

Design changes or operations actions that could cause a reduction of ventilation flow (i.e., air exchange rate) in waste transfer-associated structures shall be evaluated to ensure that the ventilation flow is not reduced below that of barometric breathing (i.e., an average air exchange rate of $0.46 \%$ of the structure volume/day). If the design change or operations action could cause a ventilation flow less than barometric breathing, installed equipment in the waste-transfer-associated structure shall meet Ignition Source Control Set 1 requirements in AC 5.10 or be removed or deenergized. 


\section{Add the following to the 5.9.3, "Applicability"}

The waste transfer-associated structure ventilation control applies to activities involving active and inactive waste transfer-associated structures (e.g., valve pits, diversion boxes, process pits, cleanout boxes).

Note: The implementation of this new control will likely require documentation of anticipated design changes and operations actions such as duct taping and interim isolation with polyurethane foam to justify why or how they can be performed to comply with this new TSR requirement.

\subsubsection{Ignition Source Controls}

There was a limited discussion of a possible control to require all installed equipment or only transfer leak detection systems in waste transfer-associated structure to meet the Ignition Source Control Set 2 requirements of TSR AC 5.10. There was a consensus that this control was not needed because the existing controls selected are preferred, and this control has unknown and potentially significant cost impacts. It was also noted that transfer leak detection systems that meet Ignition Source Control Set 2 are already required for some waste transfer-associated structures and are being used whenever existing leak detection systems are upgraded.

Note: As discussed in Sections 2.2 and 3.2, flammable gas deflagrations in waste transfer-associated structures can be caused by flammable gases that enter waste transfer-associated structures from the headspace of a directly connected tank (i.e., SSTs, DSTs, DCRTs, and catch tanks). These flammable gases hazards were not addressed at the November 30, 1999 and April 19, 2000 control decision meetings since they are addressed as part of the flammable gas controls for the connected tank. 
RPP-5555 REV 0

This page intentionally left blank. 


\section{RPP-5555 REV 0}

\subsection{REFERENCES}

Bacon, R. F., 1996, Justification for Continued Operation for Flammable Gas Unreviewed Safety Question, (letter 9653371 to J. E. Kinzer, DOE-RL, July 31), Westinghouse Hanford Company, Richland, Washington.

CHG, 2000a, Tank Waste Remediation System Final Safety Analysis Report,

HNF-SD-WM-SAR-067, Rev. 1, as amended, CH2M HILL Hanford Group, Inc., Richland, Washington.

CHG, 2000b, Tank Waste Remediation System Technical Safety Requirements,

HNF-SD-WM-TSR-006, Rev. 1, as amended, CH2M HILL Hanford Group, Inc.,

Richland, Washington.

FDNW, 1998, Calculation Note on Flammable Gas in Waste Transfer Lines, HNF-2251, Fluor

Daniel Northwest, Inc., Richland, Washington.

FDNW, 1999, Hazard Evaluation for Waste Transfer System Piping Flammable Gas Hazards, HNF-5334, Fluor Daniel Northwest, Inc., Richland, Washington.

LMHC, 1999, Empirical Rate Equation Model and Rate Calculations of Hydrogen Generation for Hanford Tank Waste, HNF-3851, Lockheed Martin Hanford Corporation, Richland, Washington.

Wagoner, J. D., 1996, Definition and Declaration of Flammable Gas Unreviewed Safety Question (USQ), (letter 96-WSD-283 to H. J. Hatch, FDH, November 1), U.S. Department of Energy, Richland Operations Office, Richland, Washington.

WHC, 1993, Barometric Pressure Variations, WHC-EP-0651, Westinghouse Hanford Company, Richland, Washington. 
RPP-5555 REV 0

This page intentionally left blank. 
RPP-5555 REV 0

APPENDIX A

CONTROL DECISION RECORD FOR FLAMMABLE GAS HAZARDS IN WASTE TRANSFER PIPING 
RPP-5555 REV 0

This page intentionally left blank.

A-ii 


\section{RPP-5555 REV 0}

\section{APPENDIX A}

\section{A1.0 CONTROL DECISION RECORD}

\section{A1.1 HAZARD/ACCIDENT TITLE:}

Flammable gas hazards (i.e., deflagrations or detonations) in waste transfer piping (i.e., primary piping and piping encasements)

\section{A1.1.1 Structures, Systems, and Components (SSCs)}

Note: Revisions to existing controls and new controls are in bold italics.

\begin{tabular}{|c|c|c|c|c|}
\hline $\begin{array}{c}\text { Structures, } \\
\text { Systems, and } \\
\text { Components }\end{array}$ & \multicolumn{2}{|c|}{ Classification } & \multirow{2}{*}{ Safety Function } & Comments \\
\cline { 2 - 3 } & $\mathrm{SC}^{*}$ & $\mathrm{SS}^{*}$ & & \\
\hline None Required & & & & \\
\hline
\end{tabular}

* $\quad \mathrm{SC}$ is safety class

SS is safety significant

\section{A1.1.2 Technical Safety Requirements (TSRs)}

Note: Revisions to existing controls and new controls are in bold italics.

\begin{tabular}{|c|c|c|}
\hline Control & Safety Function & Comments \\
\hline None Required & & \\
\hline
\end{tabular}




\section{RPP-5555 REV 0}

\section{A1.1.3 Defense-In-Depth Controls}

Note: Revisions to existing controls and new controls are in bold italics.

\begin{tabular}{|c|c|c|}
\hline Control & Safety Function & Comments \\
\hline Flush transfer lines after use & $\begin{array}{l}\text { Reduce waste material in transfer } \\
\text { lines to limit the production of } \\
\text { flammable gas }\end{array}$ & - \\
\hline $\begin{array}{l}\text { Safety SSCs and TSRs that } \\
\text { provide for the detection of } \\
\text { waste leaks from primary piping } \\
\text { into piping encasements } \\
\text { (See Comments) }\end{array}$ & $\begin{array}{l}\text { Detect waste leaks from primary } \\
\text { piping into piping encasements that } \\
\text { may create a flammable gas hazard }\end{array}$ & $\begin{array}{l}\text { Safety SSCs: piping encasements, } \\
\text { transfer leak detection systems } \\
\text { TSRs: LCO 3.1.3, Transfer Leak } \\
\text { Detection Systems; AC 5.12, Transfer } \\
\text { Controls; AC 5.13, Encasement Seal } \\
\text { Loop Controls; AC 5.20, Transfer } \\
\text { Pump Administrative Lock Control } \\
\end{array}$ \\
\hline $\begin{array}{l}\text { Encasement leak detection } \\
\text { systems }\end{array}$ & $\begin{array}{l}\text { Detect waste leaks from primary } \\
\text { piping into piping encasements that } \\
\text { may create a flammable gas hazard }\end{array}$ & -- \\
\hline $\begin{array}{l}\text { Excavation controls detailed in } \\
\text { Hanford Site procedures }\end{array}$ & Prevent ignition of flammable gas & $\begin{array}{l}\text { Reduces the likelihood of inadvertently } \\
\text { intruding into waste transfer piping } \\
\text { potentially containing flammable gas }\end{array}$ \\
\hline $\begin{array}{l}\text { Transfer controls requiring } \\
\text { vehicle restrictions or concrete } \\
\text { shielding systems surrounding } \\
\text { overground transfer lines } \\
\text { (TSR AC 5.12.2.a, fifth bullet) }\end{array}$ & Prevent ignition of flammable gas & $\begin{array}{l}\text { Reduces the likelihood of vehicle } \\
\text { collisions with overground transfer lines } \\
\text { potentially containing flammable gas. } \\
\text { Concrete shielding systems are safety } \\
\text { SSCs. }\end{array}$ \\
\hline $\begin{array}{l}\text { Hazardous Material Protection } \\
\text { Program (e.g., HASP, industrial } \\
\text { safety) (TSR AC 5.24.2.b) }\end{array}$ & $\begin{array}{l}\text { Protect facility workers from } \\
\text { potential flammable gas hazards in } \\
\text { waste transfer piping }\end{array}$ & -- \\
\hline $\begin{array}{l}\text { Emergency Preparedness } \\
\text { (TSR AC 5.14.2.d) }\end{array}$ & $\begin{array}{l}\text { Require response to waste leaks } \\
\text { from primary piping into piping } \\
\text { encasements to prevent flammable } \\
\text { gas deflagrations or detonations } \\
\text { Mitigate the consequences of a } \\
\text { flammable gas deflagration or } \\
\text { detonation }\end{array}$ & $\ldots$ \\
\hline
\end{tabular}

${ }^{a}$ Note that failure to meet the piping encasement safety function could actually decrease the flammable gas hazard risk from primary piping waste leaks. 
RPP-5555 REV 0

\section{APPENDIX B}

\section{CONTROL DECISION RECORD FOR FLAMMABLE GAS HAZARDS IN} WASTE TRANSFER-ASSOCIATED STRUCTURES 
RPP-5555 REV 0

This page intentionally left blank.

B-ii 


\section{APPENDIX B}

\section{B1.0 CONTROL DECISION RECORD FOR FLAMMABLE GAS HAZARDS IN WASTE TRANSFER-ASSOCIATED STRUCTURES}

\section{B1.1 HAZARD/ACCIDENT TITLE:}

Flammable gas hazards (i.e., deflagrations or detonations) in waste transfer-associated structures.

\section{B1.1.1 Structures, Systems, and Components (SSCs)}

Note: Revisions to existing controls and new controls are in bold italics.

\begin{tabular}{|l|c|c|l|l|}
\hline \multicolumn{1}{|c|}{$\begin{array}{c}\text { Structures, } \\
\text { Systems, and } \\
\text { Components }\end{array}$} & \multicolumn{2}{|c|}{ Classification } & \multicolumn{1}{c|}{ Safety Function } & Comments \\
\cline { 2 - 3 } & $\mathrm{SC}^{*}$ & $\mathrm{SS}^{*}$ & & \\
\hline $\begin{array}{l}\text { Safety SSCs that } \\
\text { detect waste leaks } \\
\text { or mistransfers } \\
\text { into waste } \\
\text { transfer-associated } \\
\text { structures }\end{array}$ & -- & $\mathrm{X}$ & $\begin{array}{l}\text { Detect waste leaks or } \\
\text { mistransfers into waste } \\
\text { transfer-associated } \\
\text { structures that may create a } \\
\text { flammable gas hazard (see } \\
\text { FSAR Sections 3.4.2.7, } \\
\text { 3.4.2.8, and 3.4.2.9) }\end{array}$ & $\begin{array}{l}\text { Safety SSCs: piping } \\
\text { encasements, transfer } \\
\text { leak detection systems }\end{array}$ \\
\hline \begin{tabular}{l} 
(See Comments) \\
\hline
\end{tabular}
\end{tabular}

$* \mathrm{SC}$ is safety class

SS is safety significant

${ }^{a}$ Note that failure to meet the piping encasement safety function could actually decrease the flammable gas hazard risk from primary piping waste leaks. 


\section{B1.1.2 Technical Safety Requirements (TSRs)}

Note: Revisions to existing controls and new controls are in bold italics.

\begin{tabular}{|c|c|c|}
\hline Control & Safety Function & Comments \\
\hline $\begin{array}{l}\text { TSRs that prevent or } \\
\text { detect waste leaks or } \\
\text { mistransfers into waste } \\
\text { transfer-associated } \\
\text { structures } \\
\text { (See Comments) }\end{array}$ & $\begin{array}{l}\text { Prevent or detect waste leaks } \\
\text { or mistransfers into waste } \\
\text { transfer-associated structures } \\
\text { that may create a flammable } \\
\text { gas hazard }\end{array}$ & $\begin{array}{l}\text { TSRs: LCO 3.1.3, Transfer Leak Detection } \\
\text { Systems; AC 5.12, Transfer Controls, } \\
\text { AC 5.13, Encasement Seal Loop Controls; } \\
\text { AC 5.20, Transfer Pump Administrative Lock } \\
\text { Controls }\end{array}$ \\
\hline $\begin{array}{l}\text { Waste } \\
\text { Transfer-Associated } \\
\text { Structure Ventilation } \\
\text { Control } \\
\text { (Revision to TSR AC 5.9) }\end{array}$ & $\begin{array}{l}\text { Prevent the accumulation of } \\
\text { flammable gases in waste } \\
\text { transfer-associated } \\
\text { structures }\end{array}$ & $\begin{array}{l}\text { Design changes or operations actions that } \\
\text { could cause a reduction of ventilation flow } \\
\text { (i.e., air exchange rate) in waste } \\
\text { transfer-associated structures shall be } \\
\text { evaluated to ensure that the ventilation flow } \\
\text { is not reduced below that of barometric } \\
\text { breathing (i.e., an average air exchange rate } \\
\text { of } 0.46 \% \text { of the structure volume/day). If the } \\
\text { design change or operations action could } \\
\text { cause a ventilation flow less than barometric } \\
\text { breathing, installed equipment in the } \\
\text { waste-transfer-associated structure shall } \\
\text { meet Ignition Source Control Set } 1 \\
\text { requirements in AC } 5.10 \text { or be removed or } \\
\text { deenergized. }\end{array}$ \\
\hline $\begin{array}{l}\text { Ignition Controls } \\
\text { (TSR AC 5.10) }\end{array}$ & $\begin{array}{l}\text { Reduce the frequency of a } \\
\text { flammable gas deflagration }\end{array}$ & $\begin{array}{l}\text { Ignition Source Control Set } 2 \text { applies to } \\
\text { activity related equipment and materials until } \\
\text { work activity entry monitoring requirements } \\
\text { are met (i.e., TSR AC 5.10, Table 5.10-1) }\end{array}$ \\
\hline $\begin{array}{l}\text { Flammable Gas } \\
\text { Monitoring Controls } \\
\text { (TSR AC 5.11) }\end{array}$ & $\begin{array}{l}\text { Reduce the frequency of a } \\
\text { flammable gas deflagration }\end{array}$ & $\begin{array}{l}\text { Manned work activity entry monitoring } \\
\text { requirements (i.e., TSR AC 5.11, } \\
\text { Table 5.11-1) }\end{array}$ \\
\hline $\begin{array}{l}\text { Emergency Preparedness } \\
\text { (TSR AC 5.14.2.d) }\end{array}$ & $\begin{array}{l}\text { Require response to waste } \\
\text { leaks or mistransfers into } \\
\text { waste transfer-associated } \\
\text { structures to prevent } \\
\text { flammable gas deflagrations } \\
\text { or detonations } \\
\text { Mitigate the consequences of } \\
\text { a flammable gas deflagration } \\
\text { or detonation }\end{array}$ & $\ldots$ \\
\hline
\end{tabular}

${ }^{a}$ Key elements of TSR AC 5.12 applicable to the prevention and detection of waste leaks or mistransfers into waste transfer-associated structures include both transfer system configuration management and operating requirements of $\mathrm{AC}$ 5.12.2.a and 5.12.2.b, respectively. 


\section{RPP-5555 REV 0}

\section{B1.1.3 Defense-in Depth Controls}

Note: Revisions to existing controls and new controls are in bold italics.

\begin{tabular}{|l|l|c|}
\hline \multicolumn{1}{|c|}{ Control } & \multicolumn{1}{c|}{ Safety Function } & Comments \\
\hline $\begin{array}{l}\text { Encasement leak detection } \\
\text { systems }\end{array}$ & $\begin{array}{l}\text { Detect waste leaks into waste } \\
\text { transfer-associated structures that } \\
\text { may create a flammable gas } \\
\text { hazard }\end{array}$ & - - \\
\hline $\begin{array}{l}\text { Drains in waste } \\
\text { transfer-associated structures }\end{array}$ & $\begin{array}{l}\text { Allow leak or mistransfer to drain } \\
\text { back to storage or catch tank; } \\
\text { prevent the generation and } \\
\text { accumulation of flammable gases } \\
\text { in the waste transfer-associated } \\
\text { structure }\end{array}$ & - - \\
\hline
\end{tabular}


RPP-5555 REV 0

This page intentionally left blank.

B-4 
RPP-5555 REV 0

\section{APPENDIX C}

\section{ASSESSMENT OF THE CONSEQUENCES OF FLAMMABLE GAS DEFLAGRATIONS IN RCSTS DIVERSION BOX 6241-A AND VENT STATION 6241-V}


RPP-5555 REV 0

This page intentionally left blank.

C-ii 


\section{RPP-5555 REV 0}

\section{Assessment of the Consequences of Flammable Gas Deflagrations in RCSTS Diversion Box 6241-A and Vent Station 6241-V}

\section{Statement of the Issue}

The consequence analysis of flammable gas deflagrations in waste transfer-associated structures in HNF-2251, Calculation Note on Flammable Gas in Waste Transfer Lines, (Section 6.0) does not consider or bound potential flammable gas deflagrations in the Replacement Cross-Site Transfer System (RCSTS) diversion box 6241-A and vent station 6241-V. Because of the large size of these two structures, ${ }^{\text {a }}$ the RCSTS hazard analysis qualitatively estimated the consequences of a flammable gas deflagration caused by a waste leak into these structures without controls as S3 (i.e., impact a receptor at the Hanford Site boundary) for diversion box 6241-A and S2 (i.e., impact a receptor at $100 \mathrm{~m}$ ) for vent station $6241-\mathrm{V}$, and binned these two potential hazardous conditions under the Flammable Gas Deflagration - SST representative accident. Without further analysis, this would require a safety-class designation for the selected safety structures, systems, and components (SSCs) that detect waste leaks or mistransfers into diversion box 6241-A (i.e., leak detection systems) to prevent this accident. This would make flammable gas hazards the only basis for the safety-class designation of the diversion box 6241-A leak detection systems if the re-evaluation of waste leak accidents shows that they do not challenge the offsite risk evaluation guidelines (REGs) established by the U.S. Department of Energy (DOE) for the Tank Waste Remediation System (TWRS) Final Safety Analysis Report (FSAR).

\section{Risk Assessment of Flammable Gas Hazards in RCSTS Diversion Box 6241-A and Vent Station 6241-V}

The cause of a postulated flammable gas deflagration in RCSTS diversion box 6241-A and vent station $6241-\mathrm{V}$ is a waste leak into these structures that results in the buildup of flammable gases to the lower flammability limit (LFL) and an ignition source (see potential hazardous conditions RCSTS-08-INTEG12 and RCSTS-09-INTEG06). The frequency of this postulated accident is estimated in the hazard analysis as "unlikely" (i.e., $10^{-4}$ to $10^{-2}$ per year). This frequency is reasonable without controls since the accident scenario first requires a significant waste leak into the RCSTS diversion box or vent station, and then the slow buildup of flammable gases to the LFL and the presence of an ignition source. Based on a conservative analysis of flammable gas generation and accumulation in HNF-2251 (Section 5.2.3.1, pages 24-26), a waste leak that fills a waste transfer-associated structure at least $1 / 3$ full is required for flammable gas concentrations to reach the LFL assuming only passive breathing (i.e., an average air exchange rate of $0.46 \%$ of the structure volume per day). This minimum waste leak is $\sim 207,000 \mathrm{~L}(\sim 54,700 \mathrm{gal})$ and $\sim 69,000 \mathrm{~L}(\sim 18,200 \mathrm{gal})$ for the diversion box and vent station, respectively. The analysis in

${ }^{a}$ From HNF-SD-WM-CN-111, Accident Consequence Calculations for Project W-058 Safety Analysis, the volume of the diversion box $6241-\mathrm{A}$ is $622 \mathrm{~m}^{3}$ (Table 2-1, page 4) or $\sim 622,000 \mathrm{~L}$ $(\sim 164,000 \mathrm{gal})$, and the volume of the vent station $6241-\mathrm{V}$ is $207 \mathrm{~m}^{3}$ (Section 2.4 , page 11 ) or $\sim 207,000 \mathrm{~L}(\sim 54,700 \mathrm{gal})$. 


\section{RPP-5555 REV 0}

HNF-2251 also shows that if a waste transfer-associated structure is filled $35 \%$ full it would take 772 days to reach the LFL. If filled $90 \%$ full, it would take 18 days.

The potential offsite radiological consequences (i.e., radiation dose) of a flammable gas deflagration in a waste transfer-associated structure containing liquid waste from HNF-2251 (Section 6.2.3.3, page 38) is:

$$
\begin{aligned}
& \mathrm{D}=\mathrm{Q} \times \mathrm{X} / \mathrm{Q}^{\prime} \times\left[\mathrm{BR} \times \mathrm{ULD}_{\text {inh }}+\mathrm{ULD}_{\text {ing }}\right] \\
& \text { where } \mathrm{D}=\text { radiation dose to the maximum offsite individual at the Hanford } \\
& \text { Site boundary } \\
& \mathrm{Q}=\text { airborne material released }=\text { MAR } \times \mathrm{ARF} \times \mathrm{RF} \times \mathrm{LPF} \\
& \text { MAR = material at risk in liters } \\
& \mathrm{ARF}=\text { airborne release fraction }=1.1 \mathrm{E}-6 \\
& \mathrm{RF} \quad=\text { respirable fraction }=1 \\
& \mathrm{LPF}=\text { leak path factor }=1 \\
& \mathrm{X} / \mathrm{Q}^{\prime}=\text { atmospheric dispersion factor }=2.83 \mathrm{E}-5 \mathrm{~s} / \mathrm{m}^{3} \\
& \mathrm{BR}=\text { breathing rate }=3.3 \mathrm{E}-4 \mathrm{~m}^{3} / \mathrm{s} \text { (light activity breathing rate) } \\
& \mathrm{ULD}_{\text {inh }}=\text { unit liter inhalation dose }=5.62 \mathrm{E} 5 \mathrm{~Sv} / \mathrm{L} \text { (mixture of } 67 \% \mathrm{AWF} \\
& \text { liquids and } 33 \% \text { AWF solids) } \\
& \mathrm{ULD}_{\text {ing }}=\text { unit liter } 24 \text { hour ingestion dose }=2.73 \mathrm{~Sv}-\mathrm{m}^{3} / \mathrm{s}-\mathrm{L} \text { (mixture of } 67 \% \\
& \text { AWF liquids and } 33 \% \text { AWF solids) }
\end{aligned}
$$

The MAR is conservatively assumed to equal the total quantity of waste leaked into the diversion box or vent station even though the ARF from DOE-HDBK-3010-94, Airborne Release Fractions/Rates and Respirable Fractions for Nonreactor Nuclear Facilities, is for blast effects from gas velocities passing over the surface of the liquid.

Using the above equation, the MAR required to cause a maximum dose at the Hanford Site boundary of $0.005 \mathrm{~Sv}(0.5 \mathrm{rem})$ (i.e., the offsite radiological REG for an unlikely event) from a flammable gas deflagration in a waste transfer-associated structure is $\sim 850,000 \mathrm{~L}(\sim 225,500$ gallons). Since this exceeds the size of the diversion box $[\sim 622,000 \mathrm{~L}(\sim 164,000$ gallons $)]$ and the vent station $[\sim 207,000 \mathrm{~L}(\sim 54,700$ gallons $)]$, any postulated flammable gas deflagration in these RCSTS structures would not challenge the offsite radiological REGs.

The potential offsite toxicological consequences (i.e., toxic material exposure) of a flammable gas deflagration in a waste transfer-associated structure containing liquid waste from HNF-2251 (Section 6.2.3.3, page 39) is:

$$
\mathrm{SOF}=\mathrm{Q} / \mathrm{T} \times \mathrm{M}
$$

where $\quad$ SOF $=$ sum-of-fractions for the maximum offsite individual at the Hanford Site boundary Note: A SOF of $>1$ indicates the REGs are exceeded

$\mathrm{Q} \quad=$ airborne material released $=$ MAR $\times$ ARF $\times$ RF $\times$ LPF

MAR = material at risk in liters

$\mathrm{ARF}=$ airborne release fraction $=1.1 \mathrm{E}-6$ 


\section{RPP-5555 REV 0}

$$
\begin{aligned}
\mathrm{RF}= & \text { respirable fraction }=1 \\
\mathrm{LPF}= & \text { leak path factor }=1 \\
\mathrm{~T}= & \text { time of release }=60 \mathrm{~s} \\
\mathrm{M}= & \text { maximum offsite individual unit release sum-of-fraction multiplier } \\
& \text { for an unlikely accident }=11 \mathrm{~s} / \mathrm{L}(67 \% \mathrm{DST} \text { liquids and 33\% DST } \\
& \text { solids })
\end{aligned}
$$

Using the above equation, the MAR required to exceed a SOF of 1 from a flammable gas deflagration in a waste transfer-associated structure is $\sim 5,000,000 \mathrm{~L}(\sim 1,300,000$ gallons). Based on the size of the diversion box [ 622,000 L ( 164,000 gallons)] and the vent station [ 207,000 L ( 54,700 gallons)], any flammable gas deflagration in these RCSTS structures would not challenge the offsite toxicological REGs.

\section{Conclusions}

Applying the methodology for calculating the consequences of flammable gas deflagrations with liquid waste present in waste transfer-associated structures from HNF-2251, the consequences of a postulated flammable gas deflagration in RCSTS diversion box 6241-A and vent station $6241-\mathrm{V}$ do not challenge the offsite REGs. This should be used to revise the estimated consequences of potential hazardous condition RCSTS-08-INTEG12 (flammable gas deflagration in diversion box 6241-A) from an S3 to an S2. These results also mean that safety SSCs selected to prevent or mitigate flammable gas hazards in waste transfer-associated structures, including RCSTS diversion box 6241-A, would be designated safety-significant for the flammable gas hazard. 
RPP-5555 REV 0

Practice 1342901112

Publication Date 22Nuv99

Attachment 02 - Sheet 1 of 1

FLUOR DANIEL NORTHWEST

TECHNICAL PEER REVIEWS

\section{CHECKLIST FOR TECHNICAL PEER REVIEW} Document Revicwed: Flanmrable Gri Defluglatior Consefuences in RCTS Diverion
Title:

Author: LJ K Mir?

Date: $3 / 15 / 00$

Scope of Review:

Yes No* NA

[X][][ ]**

$[x][][]$

$[X][][]$

[X][ ] ]

[] [ ] $[x]$

[x][][]

[X][][]

[ ] [ ] $x]$

$[x][][]$

A $][$ ] [ ]

[ ] $][x]$

[ ] $][X]$

$\alpha][][]$

$\infty][][$

[x][][]

[x][ ] [ ]

(x)[][]

[] $[X]^{* *}$

Previous reviews complete and cover analysis, up to scope of this review, with no gaps.

Problem completely defined.

Accident scenarios developed in a clear and logical manner.

Necessary assumptions explicitly stated and supported.

Computer codes and data files documented.

Data used in calculations explicitly stated in document

Data checked for consistency with original source information as applicable.

Mathematical derivations checked including dimensional consistency of results.

Models appropriate and used within range of validity, or use outside range of cstablished validity justified.

$\mathbb{K}][$ ] [ ] Document approved (for example, the revicwor affirms the technical accuracy of the document).

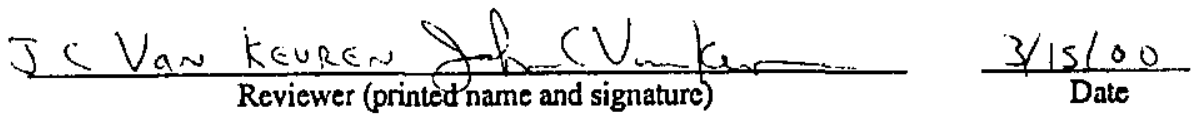

* All "no" responses must be cxplained below or on an additional sheet.

** Any calculations, comments, or notes generated as part of this review should be signed, dated, and attached to this checklist. The material should be labeled and recorded in such a manner as to be intelligible to a tochnically qualified third party. 
RPP-5555 REV 0

ATTACHMENT 1

AGENDA FOR CONTROL DECISION MEETINGS ON NOVEMBER 30 AND

DECEMBER 1, 1999 TO ADDRESS WASTE TRANSFER SYSTEM

FLAMMABLE GAS HAZARDS

[Note: The control decision meetings lasted only one day (i.e., all agenda items were covered on November 30, 1999).] 
RPP-5555 REV 0

This page intentionally left blank.

Att 1-ii 
Agenda for Control Decision Meetings on November 30 and December 1, 1999 to Address Waste Transfer System Flammable Gas Hazards

November 30, 1999 (Tuesday)

Note: All times are estimates and may vary.

8:30-9:00 Introduction
A. Purpose
B. Scope
C. Process

9:00-9:15 Background

A. Flammable gas USQ

B. Basis of existing controls (i.e., JCO)

9:15-9:45 Waste Transfer System Description

9:45-10:15 Potential Flammable Gas Hazardous Conditions in Waste Transfer System (HNF-5334)

\section{0:15-10:30 Break}

10:30-11:00 Consequences of Flammable Gas Deflagrations/Detonations in Waste Transfer Systems (HNF-2251)

\section{1:00-12:00 Waste Transfer Piping Control Decision}
A. Existing Controls
B. Possible Controls
(An initial list of possible new or revised controls with observations for and against will be presented to initiate the control decision discussion)
C. Selected Controls

\section{December 1, 1999 (Wednesday)}

Note: All times are estimates and may vary.

\section{8:30-10:15 Non-Tank Associated Structures Control Decision}

A. Existing Controls

(An initial list of possible new or revised controls with observations for and against will be presented to initiate the control decision discussion)

C. Selected Controls

\section{0:15-10:30 Break}

\section{0:30-12:00 Summary and Path Forward}


RPP-5555 REV 0

This page intentionally left blank.

Att 1-2 
RPP-5555 REV 0

ATTACHMENT 2

\section{ATTENDANCE LIST FOR THE CONTROL DECISION MEETING ON NOVEMBER 30, 1999 TO ADDRESS WASTE TRANSFER SYSTEM FLAMMABLE GAS HAZARDS}




\section{RPP-5555 REV 0}

This page intentionally left blank.

Att 2-ii 


\section{RPP-5555 REV 0}

Attendance Record of the Control Decision Meeting on November 30, 1999 to Address Waste Transfer Systems Flammable Gas Hazards

\begin{tabular}{|c|c|c|}
\hline Name & Organization & Telephone Number \\
\hline LARRY KRIPPS & NSrL & $376-1061$ \\
\hline Tom Goptz. & $1 / 5 \& 2$ & $373-4818$ \\
\hline dian-Shun Shum & $O R P-T S D$ & $373-7655$ \\
\hline DAN $R \in B \in R G E R$ & DST-ENG-R & $373-3426$ \\
\hline PAUL KISON & $S S T-5 N G K$ & $373 / 938$ \\
\hline$R_{1<K} K$ Huckteldt & PPP Safety & $372-3212$ \\
\hline Daue Bratzel & $N S \notin L$ & $373-3579$ \\
\hline Toha Vankeurin & FDNW & $376-2920$ \\
\hline MILTON V. SHULTZ & FFS: & $376-2215$ \\
\hline Mike GR155by & $N S\{L$ & $372-19.7$ \\
\hline Toel thebdon & $Q A$ & $373-2242$ \\
\hline Del SeoT & Faci Operations & $373-5480$ \\
\hline & - & \\
\hline & & \\
\hline & & \\
\hline & & \\
\hline & & \\
\hline & & \\
\hline & & \\
\hline & & \\
\hline & & \\
\hline & & \\
\hline & & \\
\hline & & \\
\hline & & \\
\hline$\therefore$ & & \\
\hline & & \\
\hline
\end{tabular}


RPP-5555 REV 0

This page intentionally left blank.

Att 2-2 
RPP-5555 REV 0

ATTACHMENT 3

PURPOSE, SCOPE, AND PROCESS FOR THE CONTROL DECISION MEETINGS TO ADDRESS WASTE TRANSFER SYSTEM FLAMMABLE GAS HAZARDS

Att 3-i 
RPP-5555 REV 0

This page intentionally left blank.

Att 3-ii 
RPP-5555 REV 0

ATTACHMENT 3

CONTROL DECISION MEETINGS TO ADDRESS WASTE TRANSFER SYSTEM FLAMMABLE GAS HAZARDS

Note: Controls include safety-class and safety-significant structures, systems, and components (SSCs); technical safety requirements (TSRs); and other controls that provided defense-in-depth or environmental protection.

\section{Purpose:}

The purpose of the control decision meetings is to review existing controls and potentially select new or revised controls to prevent or mitigate flammable gas hazards in waste transfer systems. The control decisions and their basis will support the resolution and closure of the Flammable Gas Unreviewed Safety Question (USQ) for waste transfer systems.

\section{Scope:}

The scope of the control decision meetings covers potential flammable gas hazards in waste transfer piping (primary piping and piping encasements) and in non-tank waste transfer-associated structures (e.g., valve pits, diversion boxes, process pits, clean out boxes).

\section{Process:}

The control decision process and the criteria for control decisions are described in the FSAR along with the methodology for the hazard and accident analyses whose results are used to identify controls. Control decision criteria are summarized in Exhibit I.

Control decisions will be based on the best available information from the hazard and accident analyses and on the technical expertise and experience of the meeting participants. Decisions will be made by consensus.

Required participants in the DCRT flammable gas hazard control decision meetings are representatives from operations, engineering (including Design Authority and cognizant engineers), and nuclear safety and licensing. Control decision meeting participants may also include representatives from process engineering, safety services, emergency management, nuclear regulatory compliance, quality assurance, radiological control, environmental, and interim stabilization operations and engineering. Personnel responsible for developing the information or performing the analysis supporting waste transfer system control decisions will be present at the control decision meetings. U.S. Department of Energy (DOE) Office of River Protection (ORP) staff have been invited to observe the control decision meetings.

The control decision meeting discussions will be documented, including the control decisions (see Exhibit II). The control decisions and their basis will be incorporated into the FSAR and TSRs through an Authorization Basis amendment to resolve and close the Flammable Gas USQ for waste transfer systems. Contractor (i.e., Tier I) and DOE review and approval of the Authorization Basis amendment will be required. 


\section{SUMMARY OF CONTROL DECISION CRITERIA}

Note: FSAR Section 3.3.1.5, "Controls Identification," contains a complete discussion of control decision criteria.

Control decision criteria are based on the following documents:

DOE 5480.23, Nuclear Safety Analysis

DOE 5480.22, Technical Safety Requirements

DOE-STD-3009-94, Preparation Guide for U.S. Department of Energy Nonreactor Nuclear Facility Safety Analysis Reports

WHC-CM-4-46, Nonreactor Facility Safety Analysis Manual, Section 6, "Technical Safety Requirements," Rev. 1, and Section 9, "Safety Classification of Structures, Systems, and Components, Rev. 2.

Risk Evaluation Guidelines:

$\underline{\text { Radiological Risk Guidelines }}$

\begin{tabular}{|l|c|c|c|}
\hline \multirow{2}{*}{ Frequency category } & \multirow{2}{*}{ Frequency range (yr-1) } & \multicolumn{2}{|c|}{ Effective dose equivalent (rem) } \\
\cline { 3 - 4 } & & Onsite & Offsite \\
\hline Anticipated & $>10^{-2}$ to $\leq 10^{0}$ & 0.5 & 0.1 \\
\hline Unlikely & $>10^{-4}$ to $\leq 10^{-2}$ & 5 & 0.5 \\
\hline Extremely unlikely & $>10^{-6}$ to $\leq 10^{-4}$ & 10 & 4 \\
\hline
\end{tabular}




\section{RPP-5555 REV 0}

Toxicological Risk Guidelines

\begin{tabular}{|l|c|c|c|}
\hline \multicolumn{1}{|c|}{ Frequency category } & \multirow{2}{*}{ Frequency range (yr-1) } & \multicolumn{2}{|c|}{ Primary concentration guidelines } \\
\cline { 3 - 4 } & & Onsite & Offsite \\
\hline Anticipated & $>10^{-2}$ to $\leq 10^{0}$ & $\leq$ ERPG-1 & $\leq$ PEL-TWA \\
\hline Unlikely & $>10^{-4}$ to $\leq 10^{-2}$ & $\leq$ ERPG-2 & $\leq$ ERPG-1 \\
\hline Extremely unlikely & $>10^{-6}$ to $\leq 10^{-4}$ & $\leq$ ERPG-3 & $\leq$ ERPG-2 \\
\hline
\end{tabular}

Notes:

ERPG $=$ Emergency Response Planning Guideline

PEL-TWA $=$ permissible exposure limit - time-weighted average.

Additional criteria to guide control decisions are the following:

- Control preferences are as follows:

1. Controls that prevent the accident versus those that mitigate its consequences

2. Passive engineered versus active engineered controls

3. Engineered controls versus administrative controls

- Controls providing significant defense-in-depth are classified as safety SSCs or are elevated to a TSR control

- TSR controls are not developed for postulated accidents resulting in only environmental consequences

- SSCs are not classified safety-class or safety-significant solely for preventing or mitigating postulated accidents resulting in environmental consequences

Other criteria that are important considerations in control decisions are listed below:

- Control reliability, availability, and maintainability

- Control effects on facility workers (i.e., increased radiation doses or toxicological exposures - ALARA issues)

- Control optimization and integration

- Control cost/benefit

- Control human factors impacts

- Control impacts on TWRS mission 


\section{CONTROL DECISION RECORD}

\section{HAZARD/ACCIDENT TITLE:}

Structures, Systems, and Components (SSCs)

\begin{tabular}{|l|l|l|l|l|}
\hline \multirow{2}{*}{$\begin{array}{c}\text { Structures, Systems, } \\
\text { and Components }\end{array}$} & \multicolumn{2}{|c|}{ Classification } & \multirow{2}{*}{ Safety Function } & Comments \\
\cline { 2 - 3 } & $\mathrm{SC}^{*}$ & $\mathrm{SS}^{*}$ & & \\
\hline & & & & \\
\hline & & & & \\
\hline & & & & \\
\hline
\end{tabular}

* SC is safety class

SS is safety significant

Technical Safety Requirements (TSRs)

\begin{tabular}{|l|l|l|}
\hline Control & Safety Function & Comments \\
\hline & & \\
\hline & & \\
\hline & & \\
\hline
\end{tabular}

\section{Defense-in Depth Controls}

\begin{tabular}{|l|l|l|}
\hline Control & Safety Function & Comments \\
\hline & & \\
\hline & & \\
\hline & & \\
\hline
\end{tabular}


RPP-5555 REV 0

ATTACHMENT 4

CONTROL DECISION MEETING PRESENTATIONS

Att 4-i 
RPP-5555 REV 0

This page intentionally left blank.

Att 4-ii 
RPP-5555 REV 0

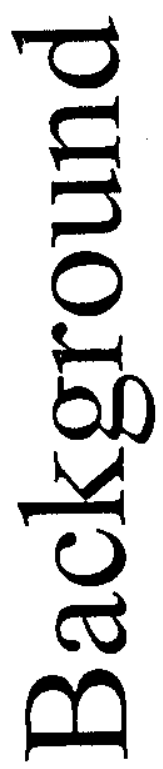

Att 4-1 


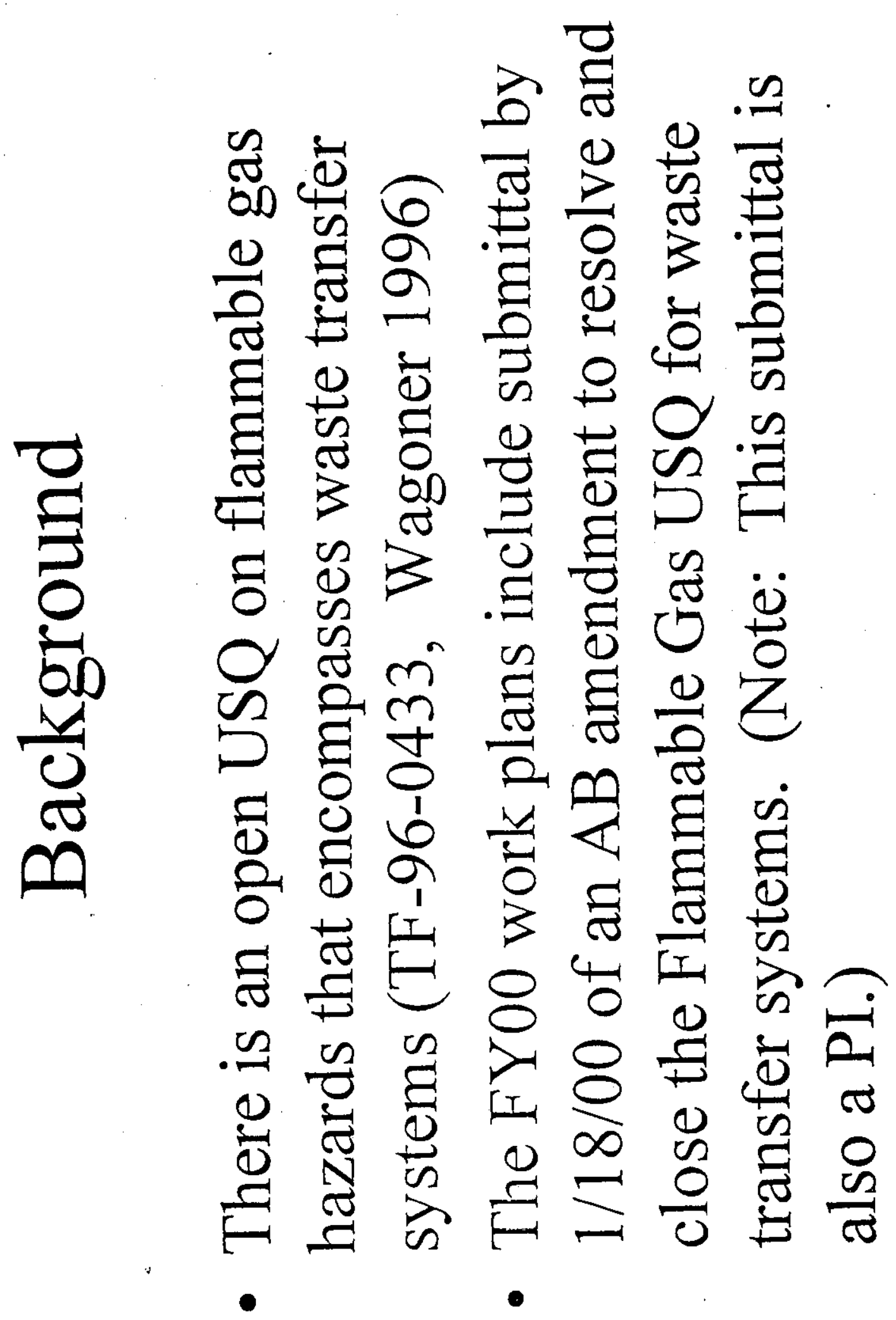




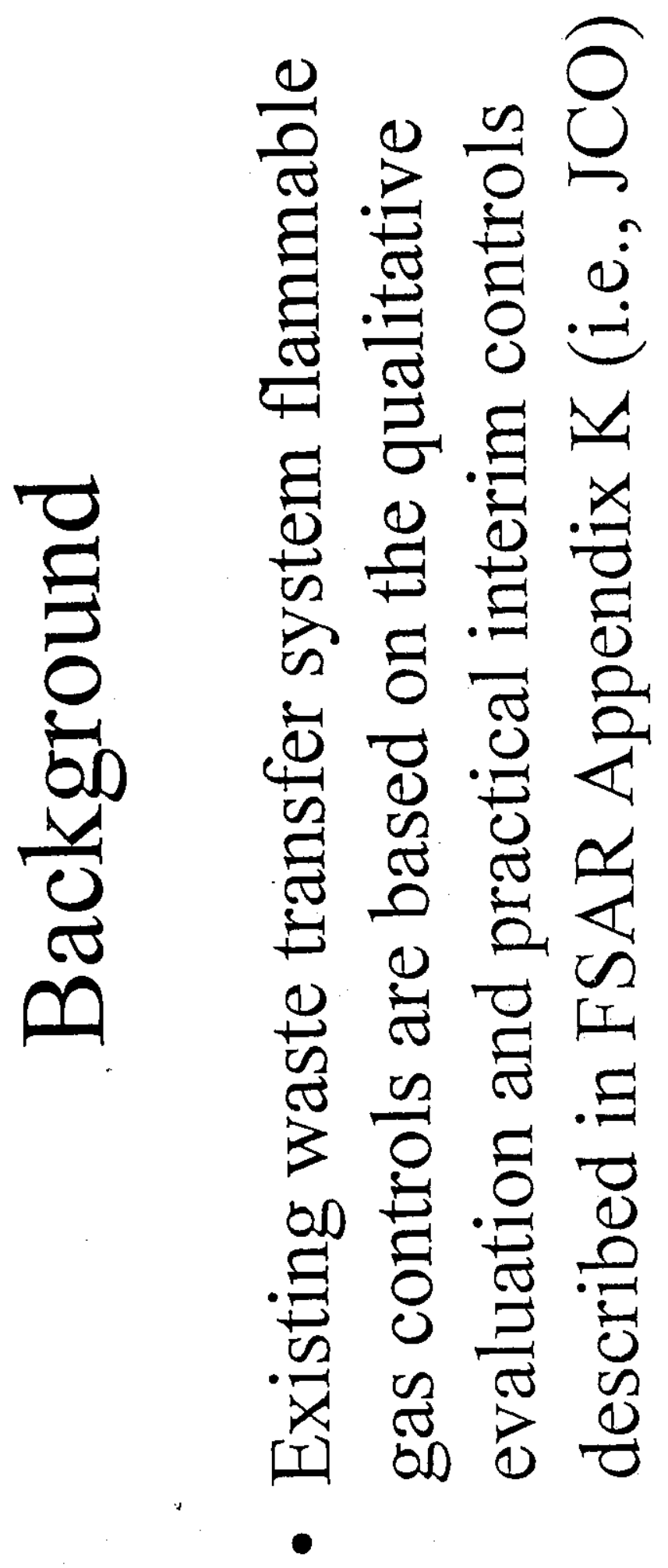


RPP-5555 REV 0

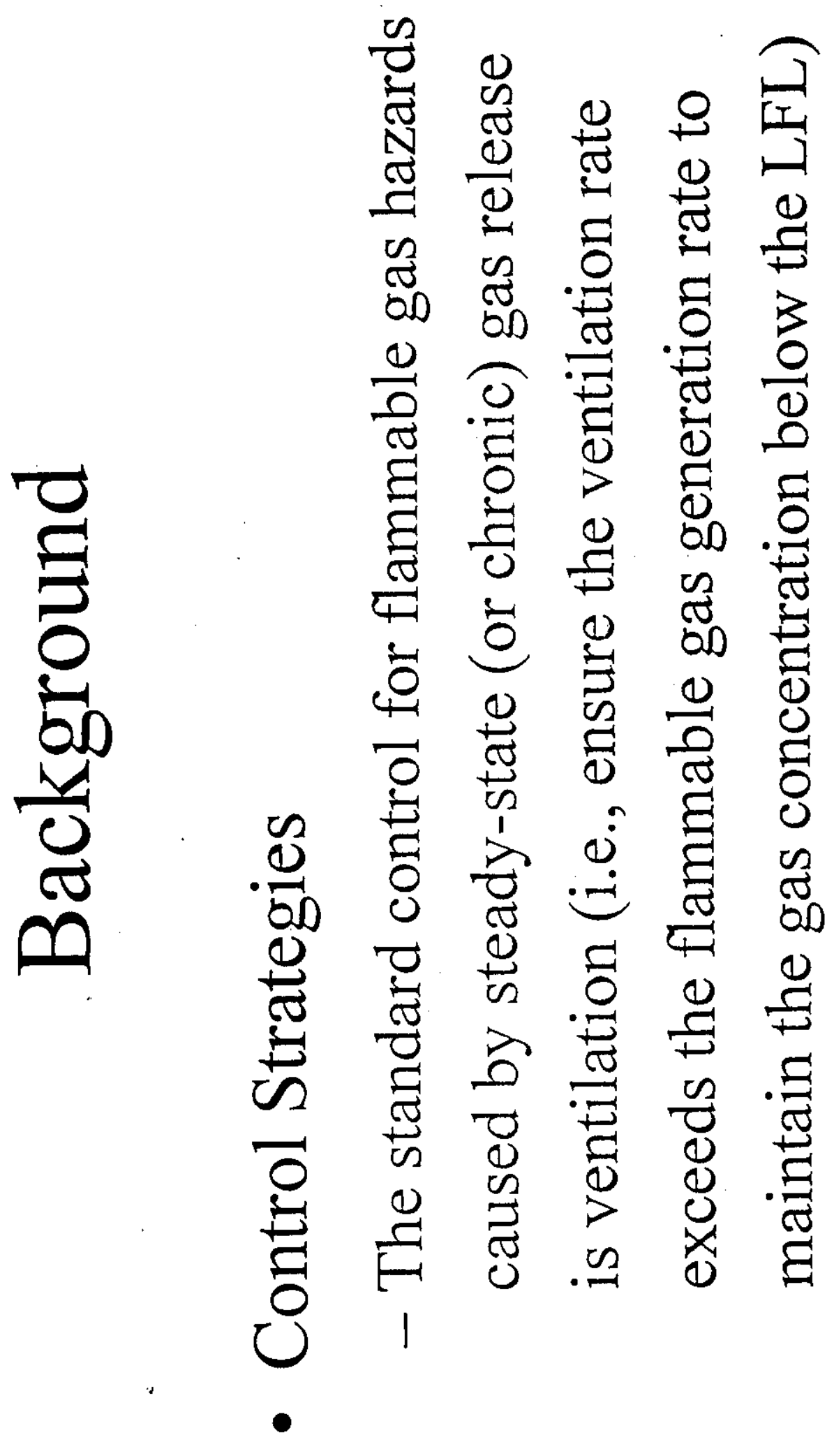




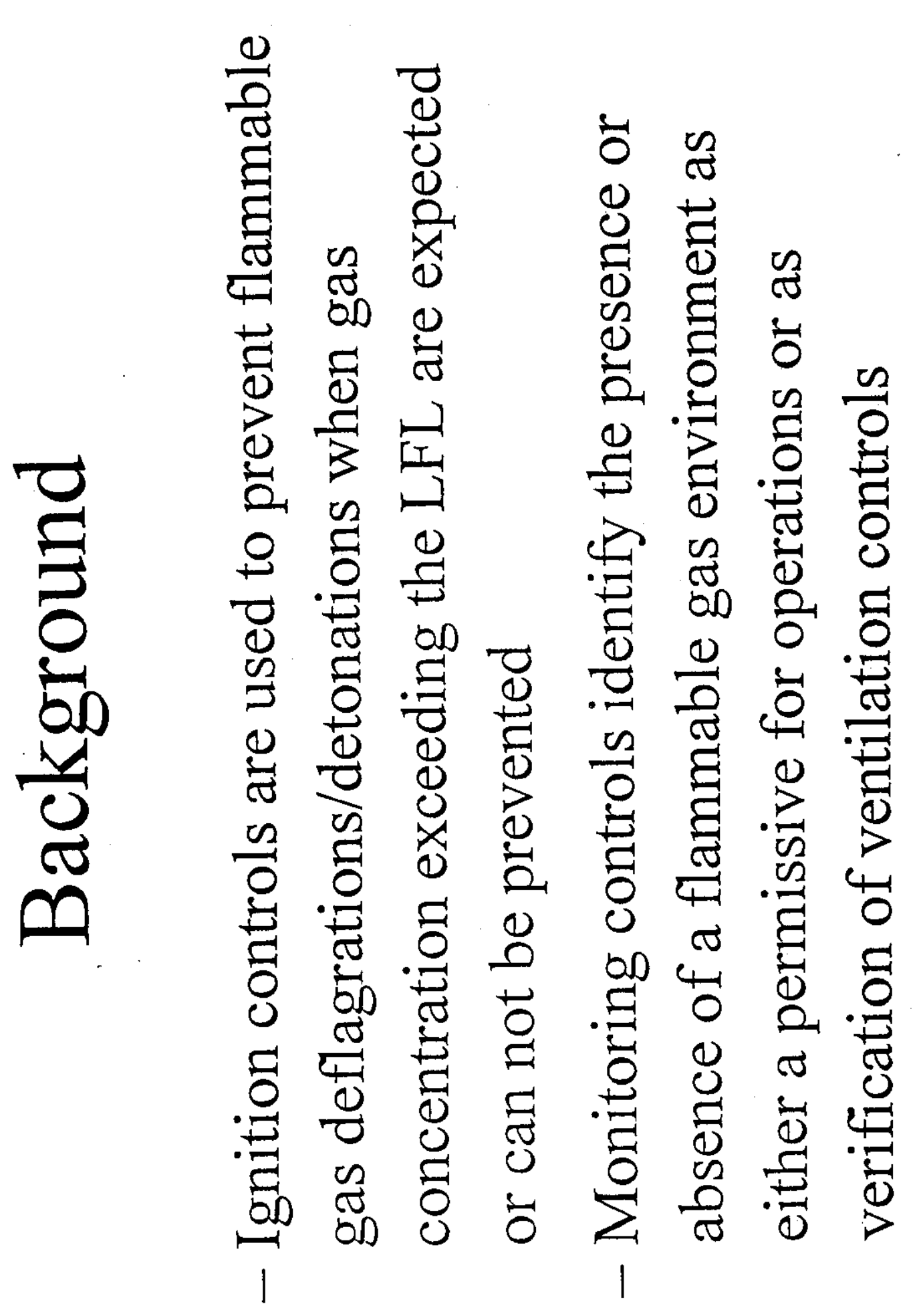




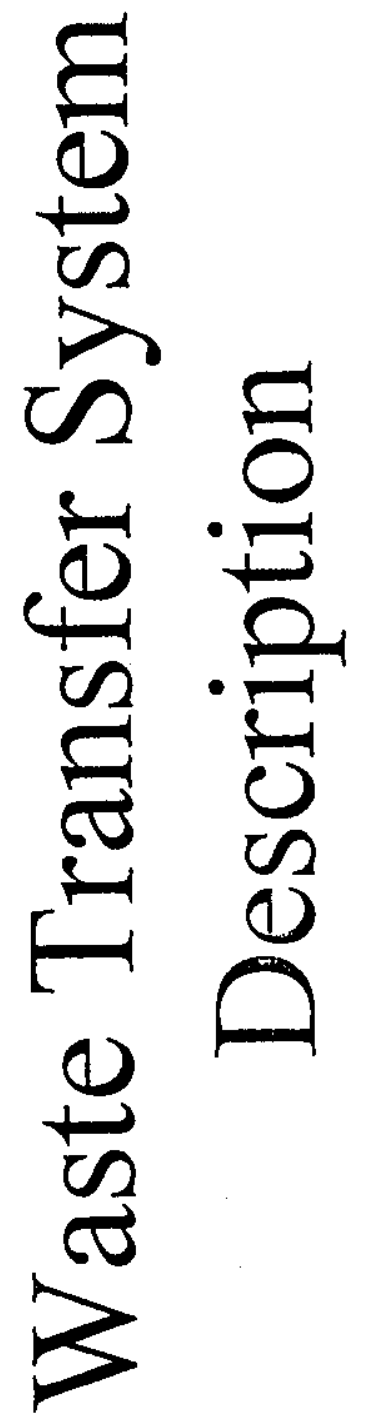

Att 4-6 


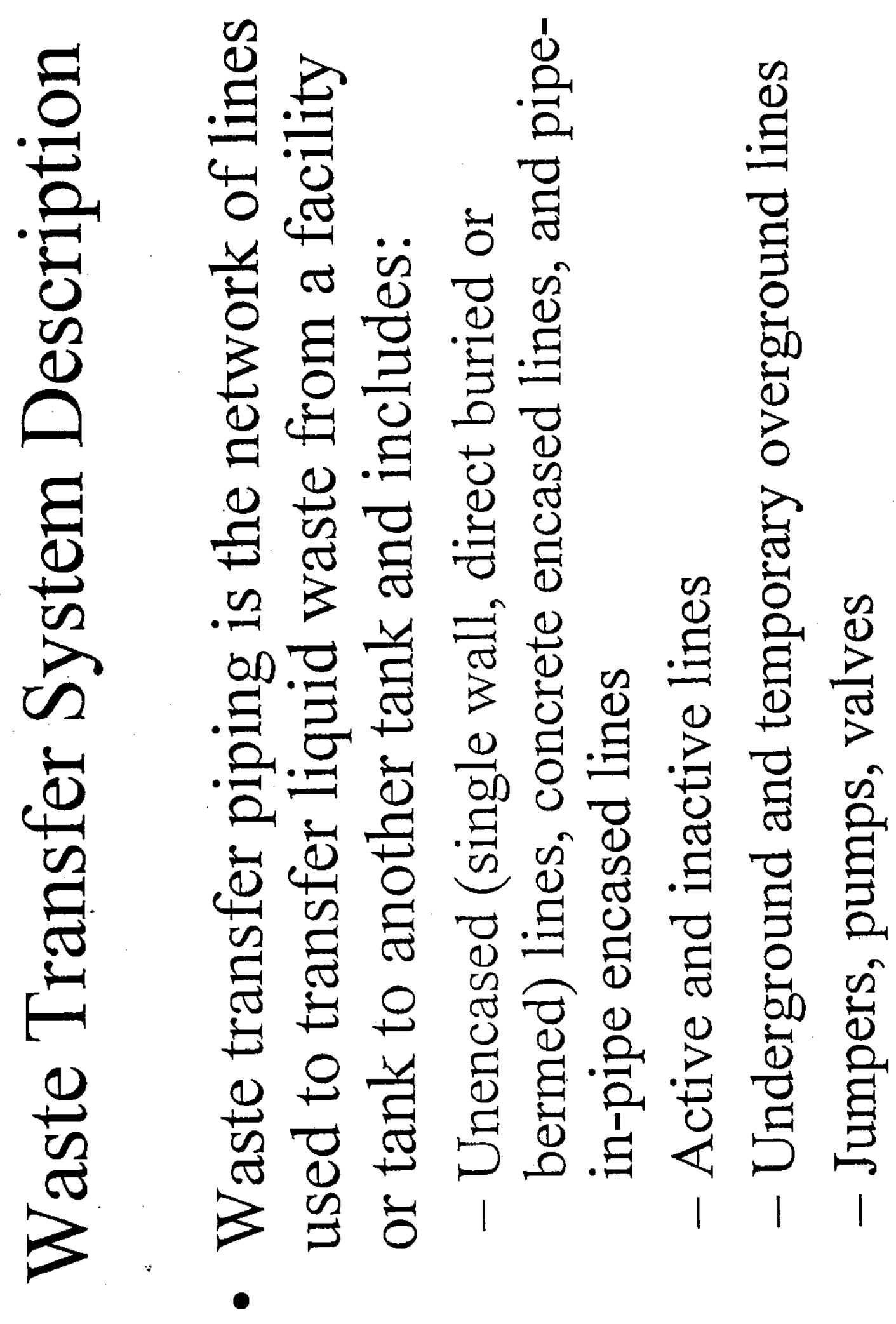




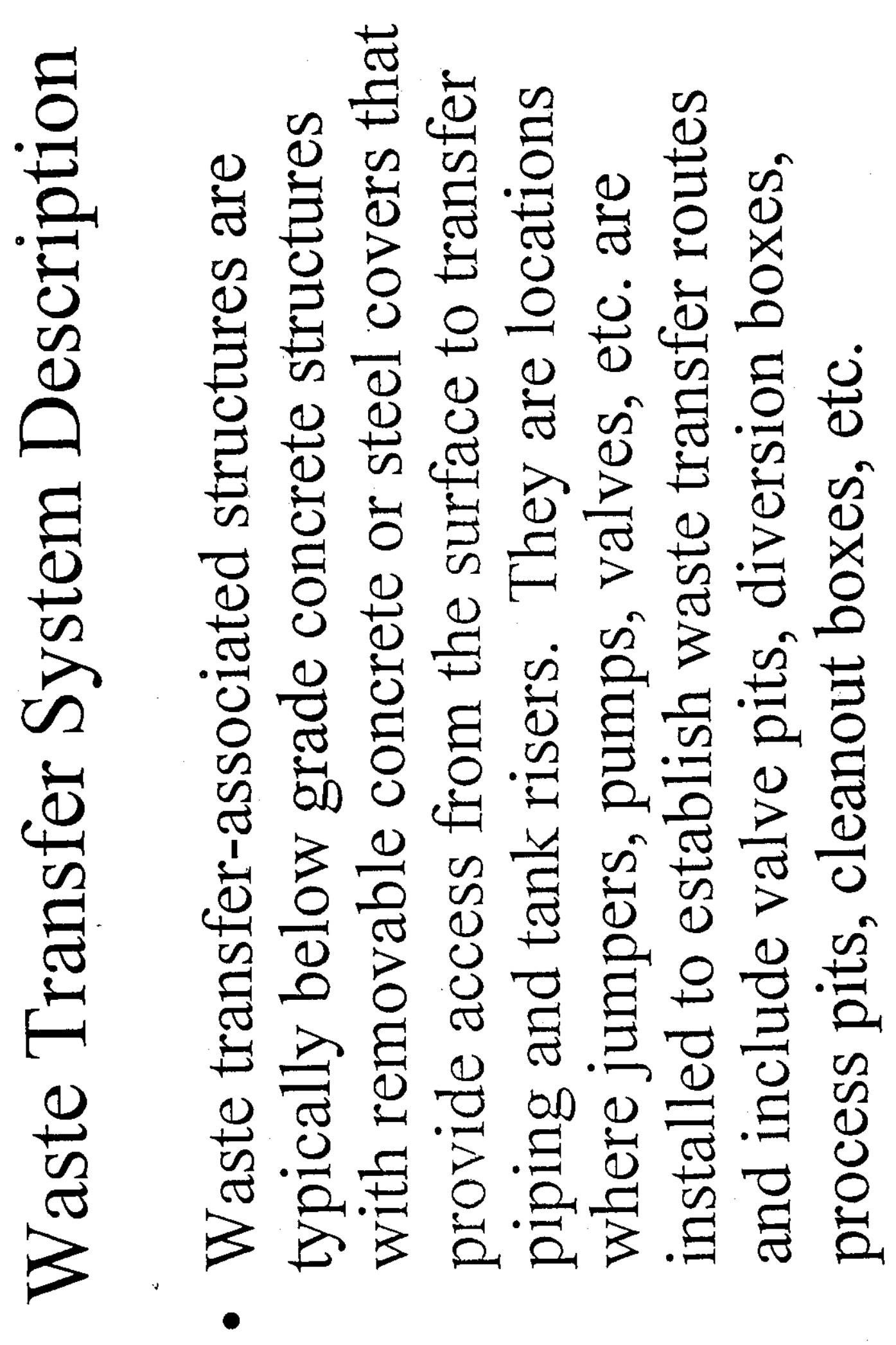




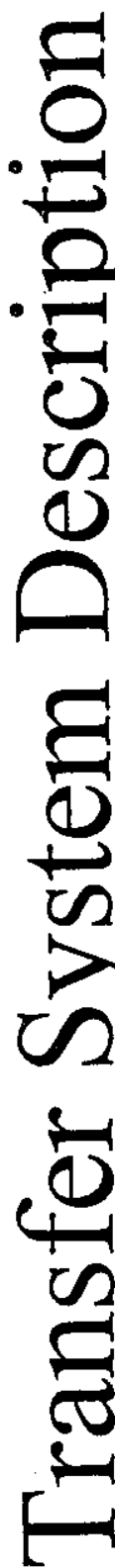

$\frac{0}{3}$

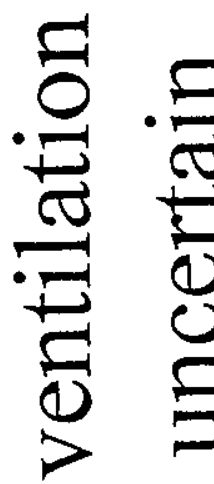

$D P$

$\Xi$

$\frac{8}{4} \cdot \frac{2}{5}$

के

3

它

当

छ

$\bar{\sigma}$

o

0

$\frac{1}{3}$

㝳

\section{.}

i்

(1)

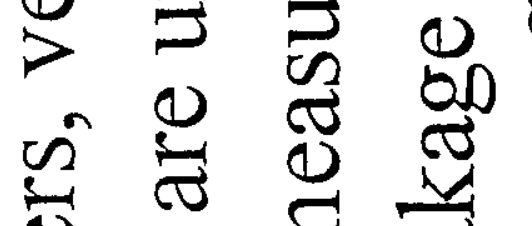

需

(1)

w

$\stackrel{0}{=} 2$

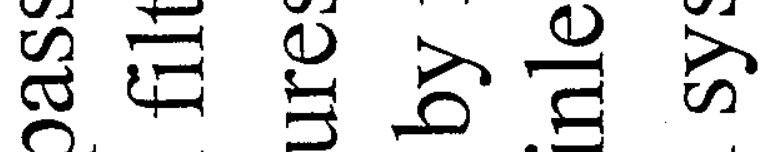

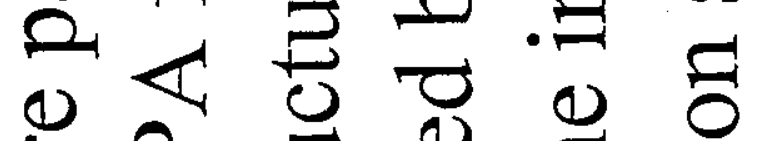

$\stackrel{0}{0}$.

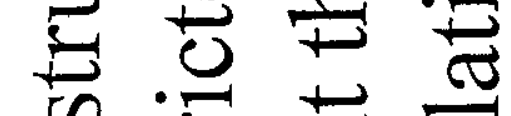

的苛㤩

0 文

E क :

긍

a

등

이욤요

ర

䒕

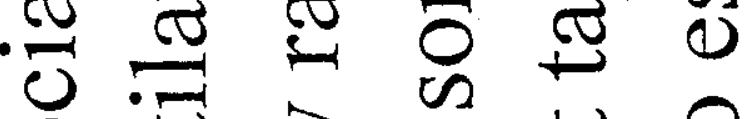

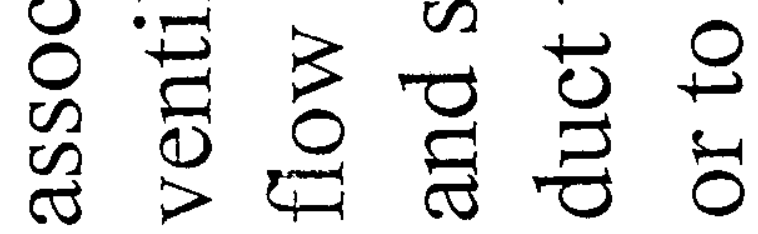

Att 4-9 


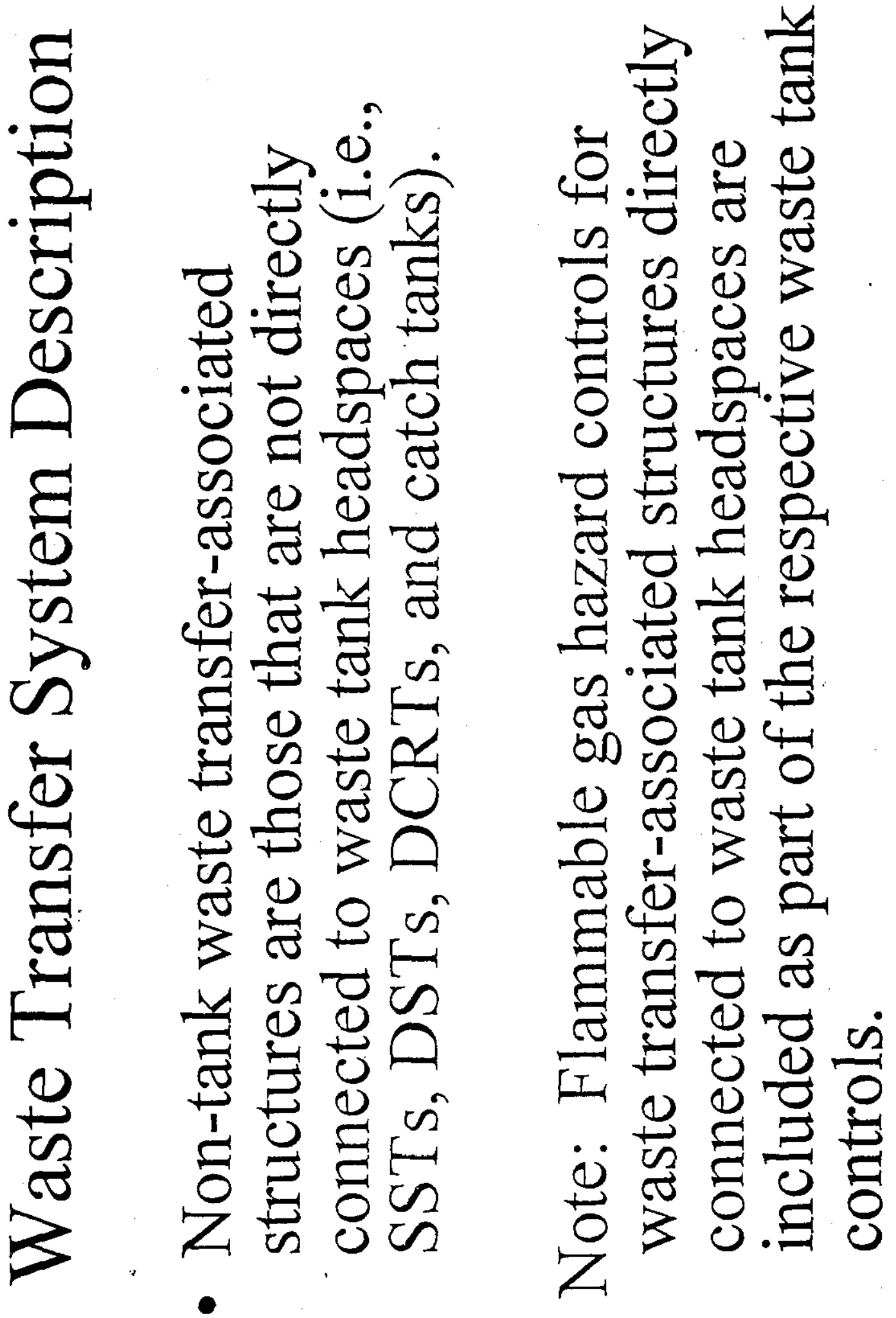




\section{RPP-5555 REV 0}

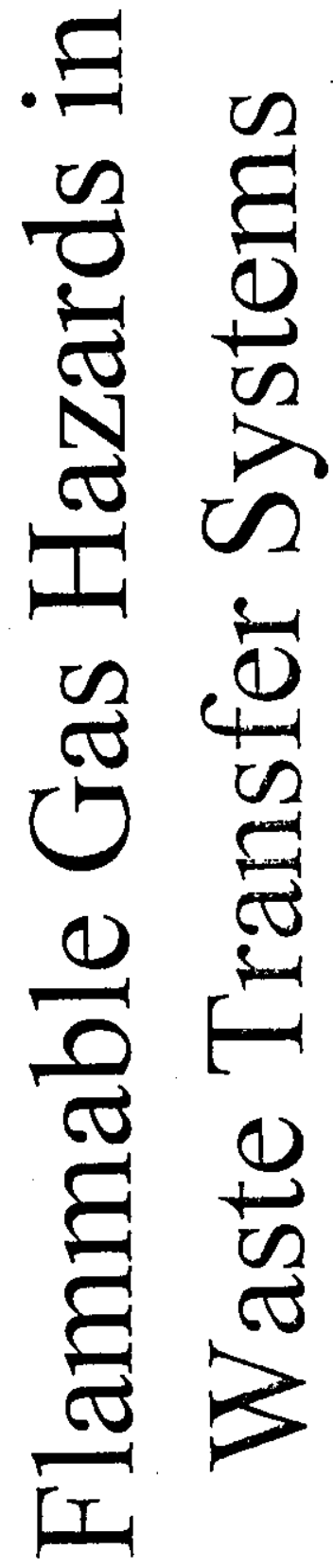

Att 4-11 


23

(1) 2 on

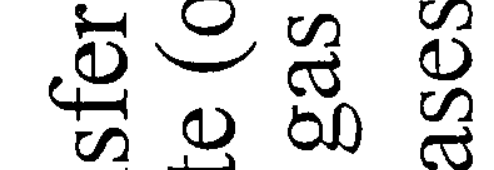

(1)

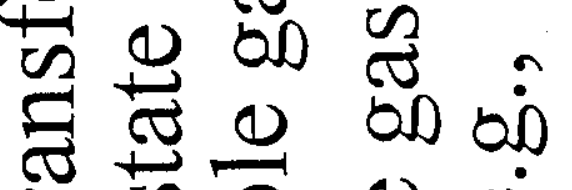

$\sum_{0}^{\infty}$

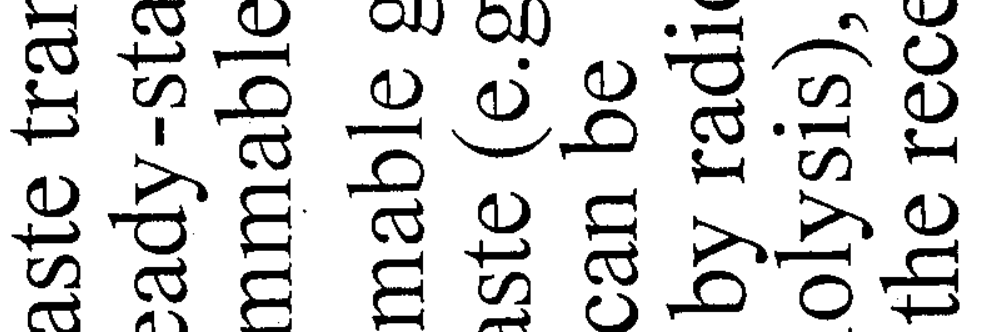

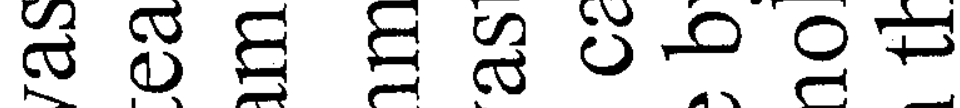

$3 \underset{\omega}{4}$

- 104

(U)

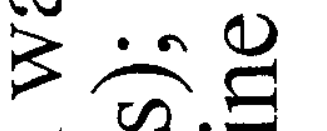

$E$

+2 (1)

$\infty$

n

글

$0^{n} 00$

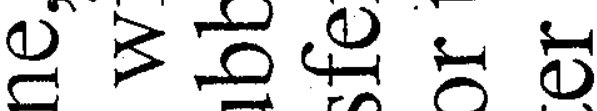

고요

$\rightarrow$

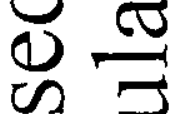

$\Xi \Xi \Xi$

.

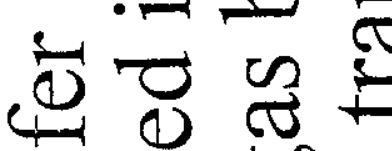

in $z$ in 000 . 0

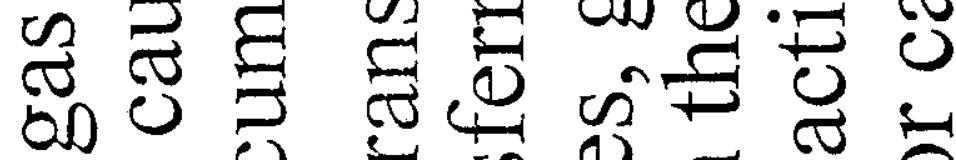

Ed

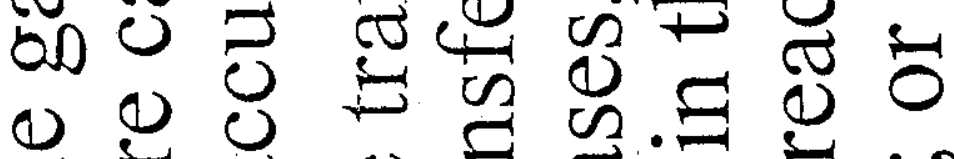

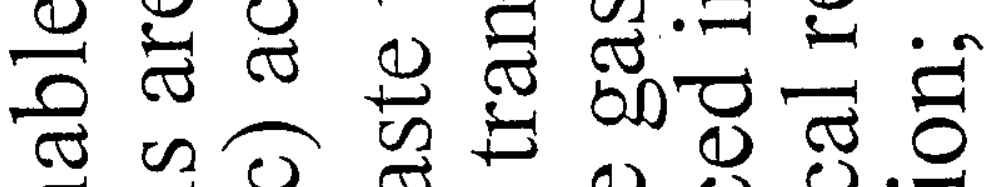

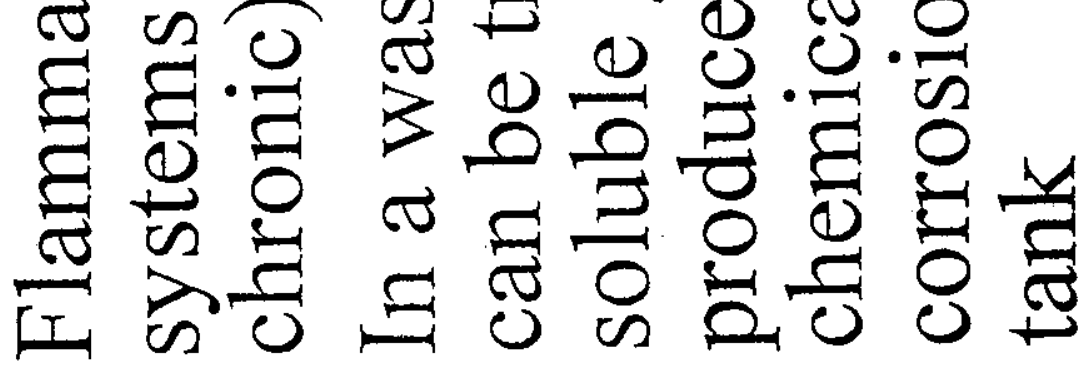

- 
RPP-5555 REV 0

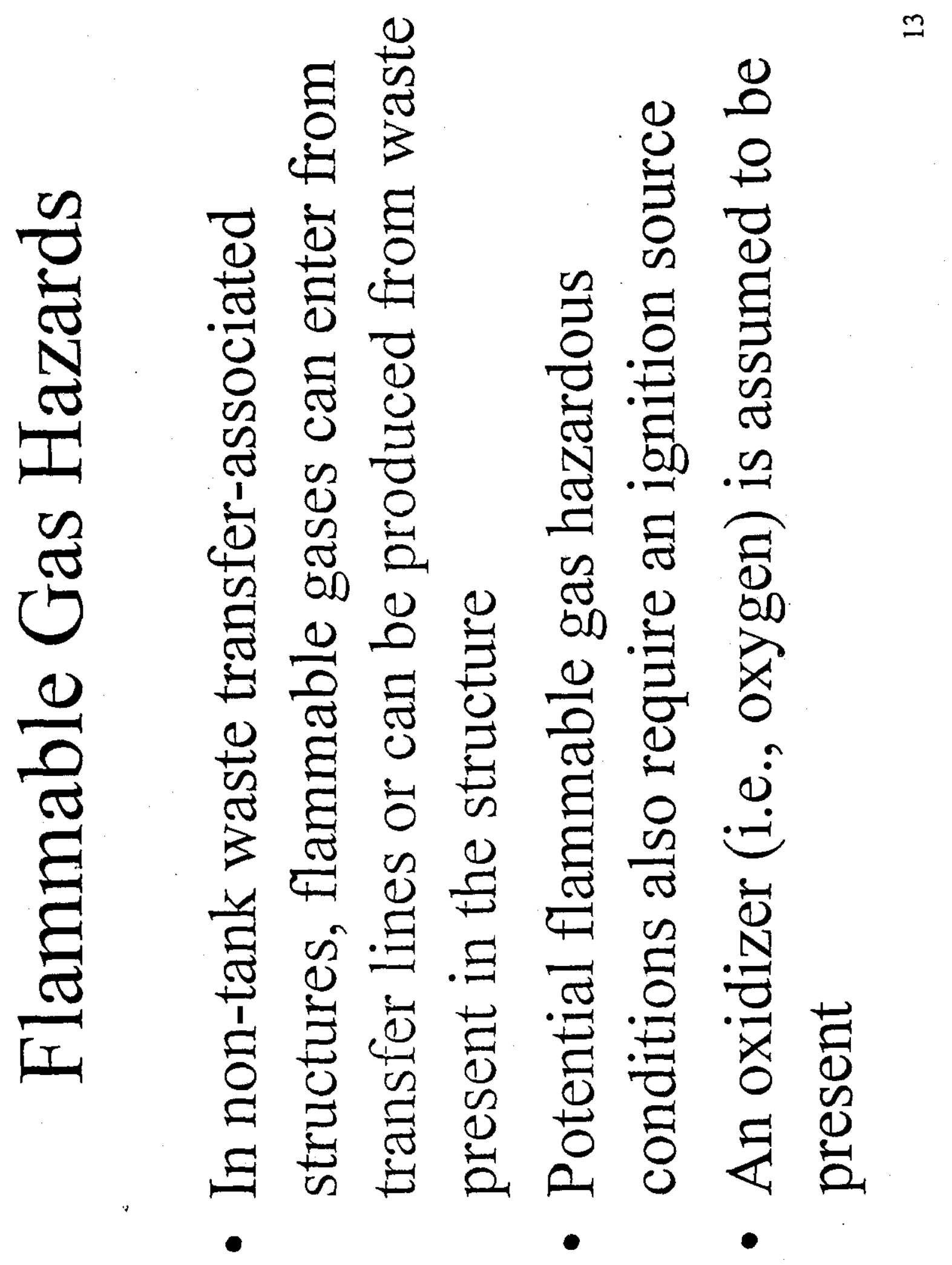


(2)

ad

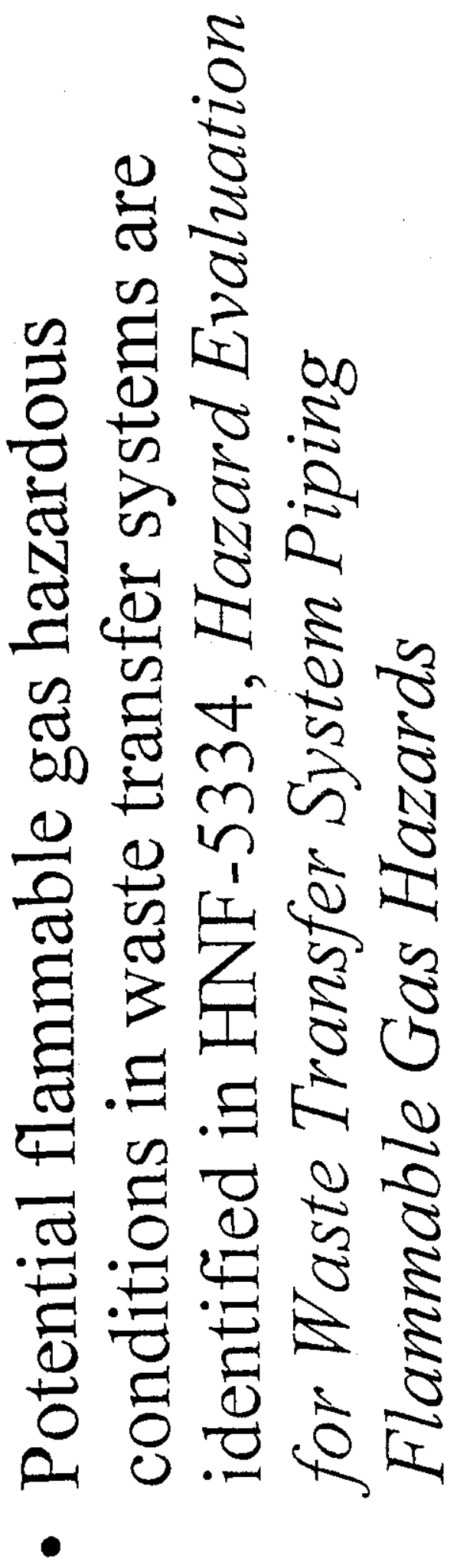



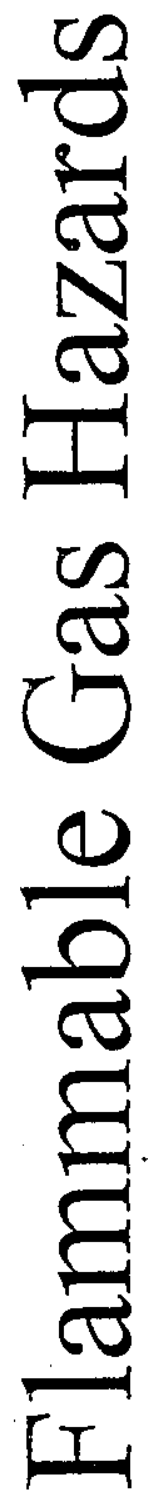

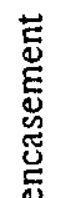

异

$\frac{.2}{2}$

竞

洁 $\stackrel{0}{\leftrightarrows}$

$\frac{1}{3}$ 总

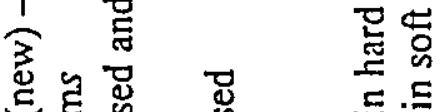

ह

范望

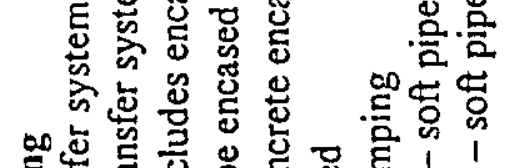

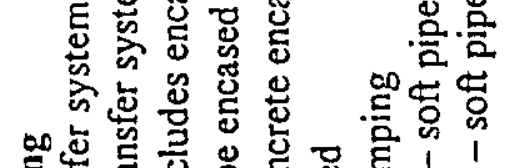

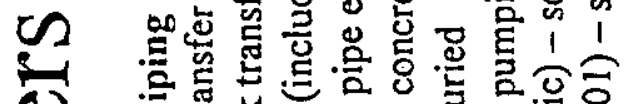

(1)

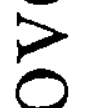

현

ह

昰总志

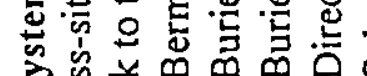

के 仓ै 造它

舫

$m$

n

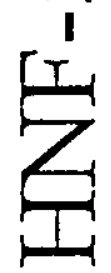

忿里
है

嵌

范

인

恶

엉

总

总.

드드

号产

范

巳空

ษั

ri

홍

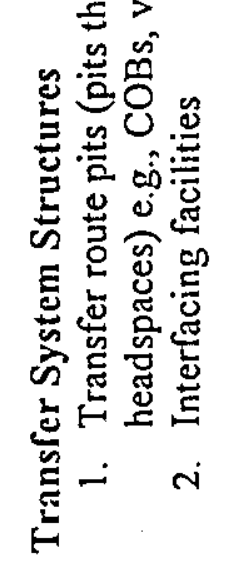

量

Ð

흥 范

용

용 巳

远㝴

无导要

密焉吉

500000

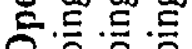

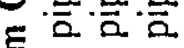

总氙

空空岕

क 氙

造点

突

E 


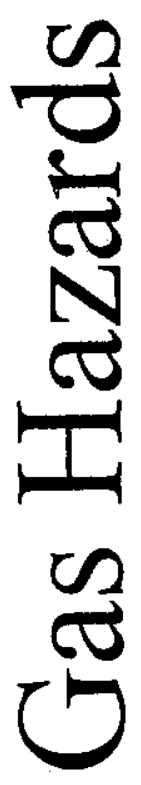

$\frac{0}{\theta}$

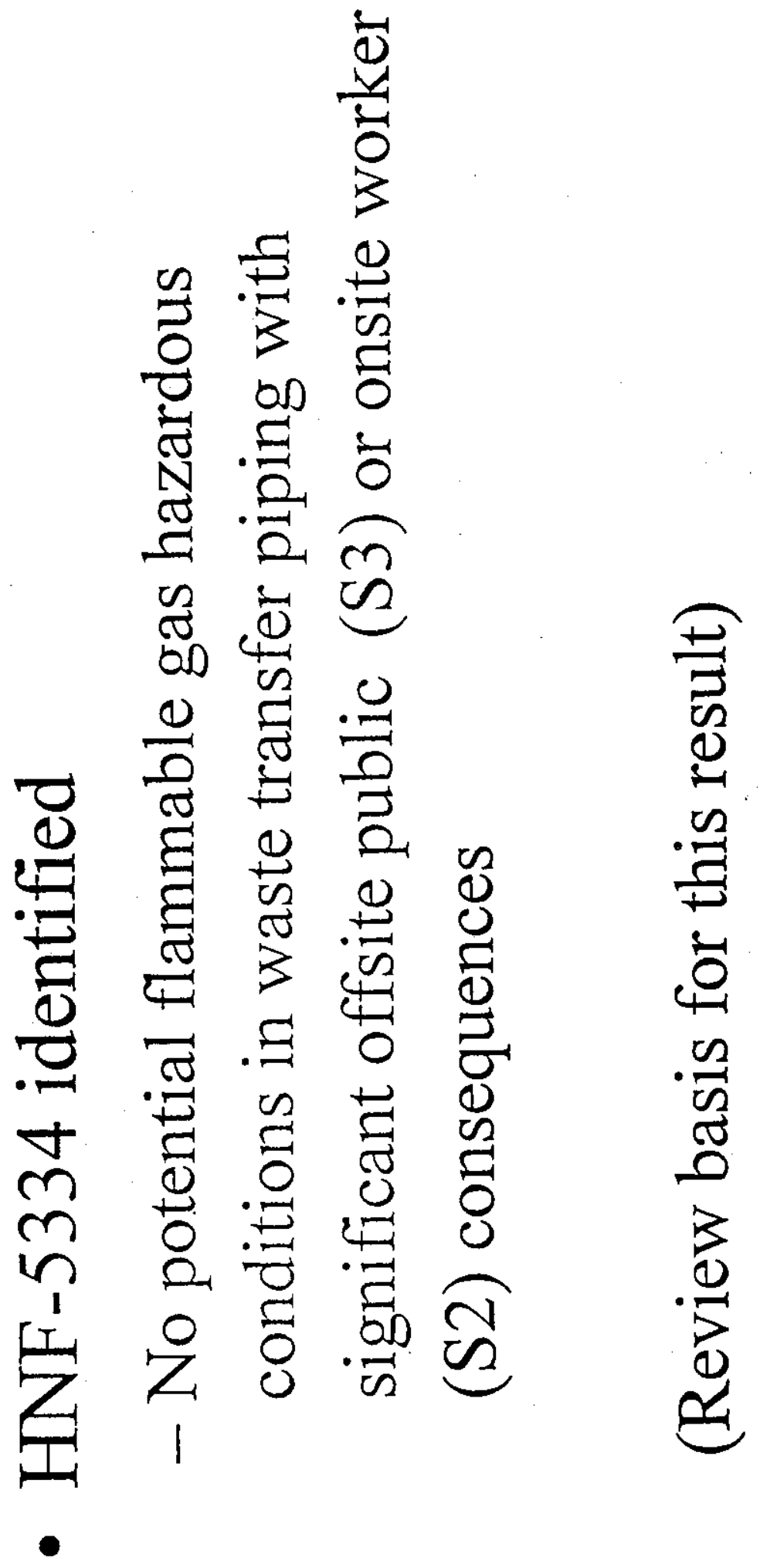




\section{RPP-5555 REV 0}

5

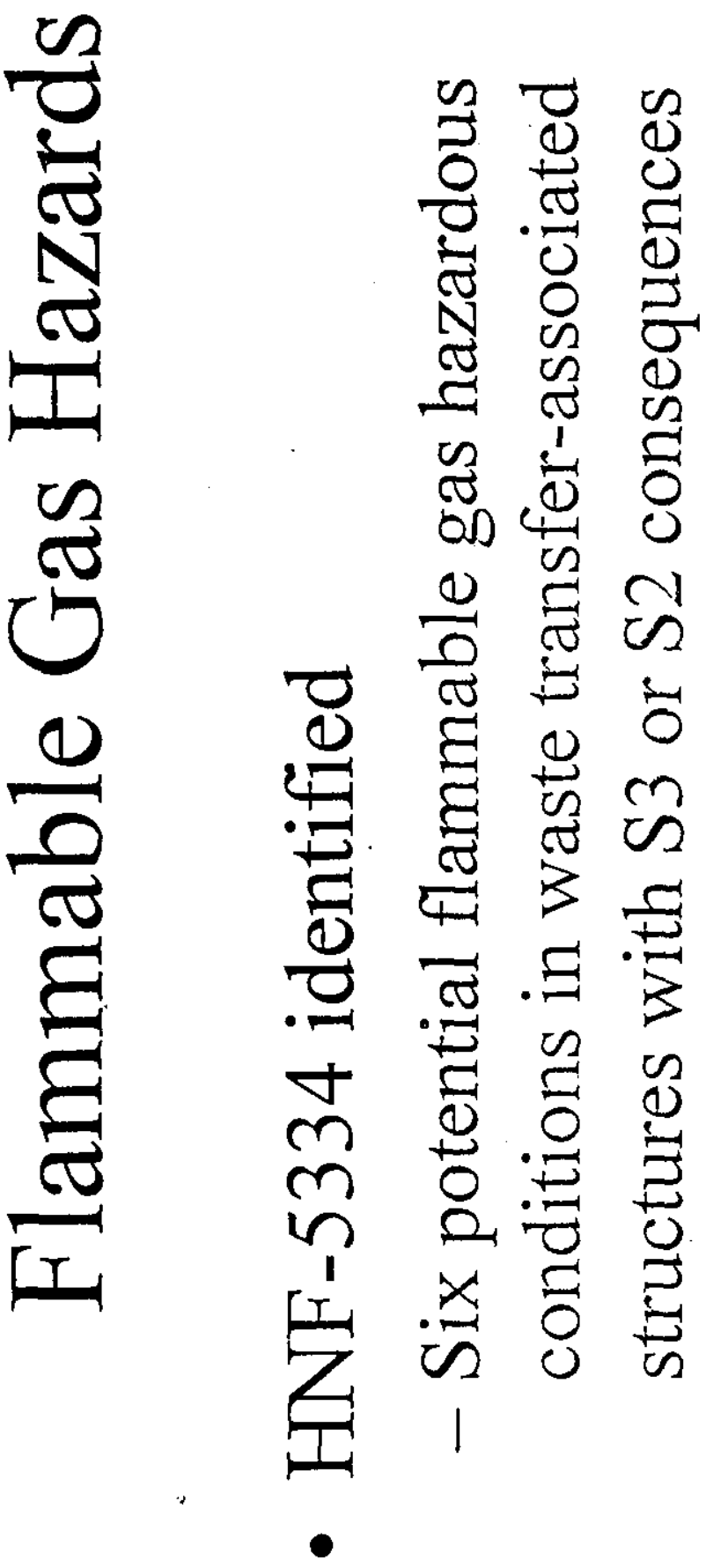

Att 4-17 
RPP-5555 REV 0

HNF-5334 Rev 0

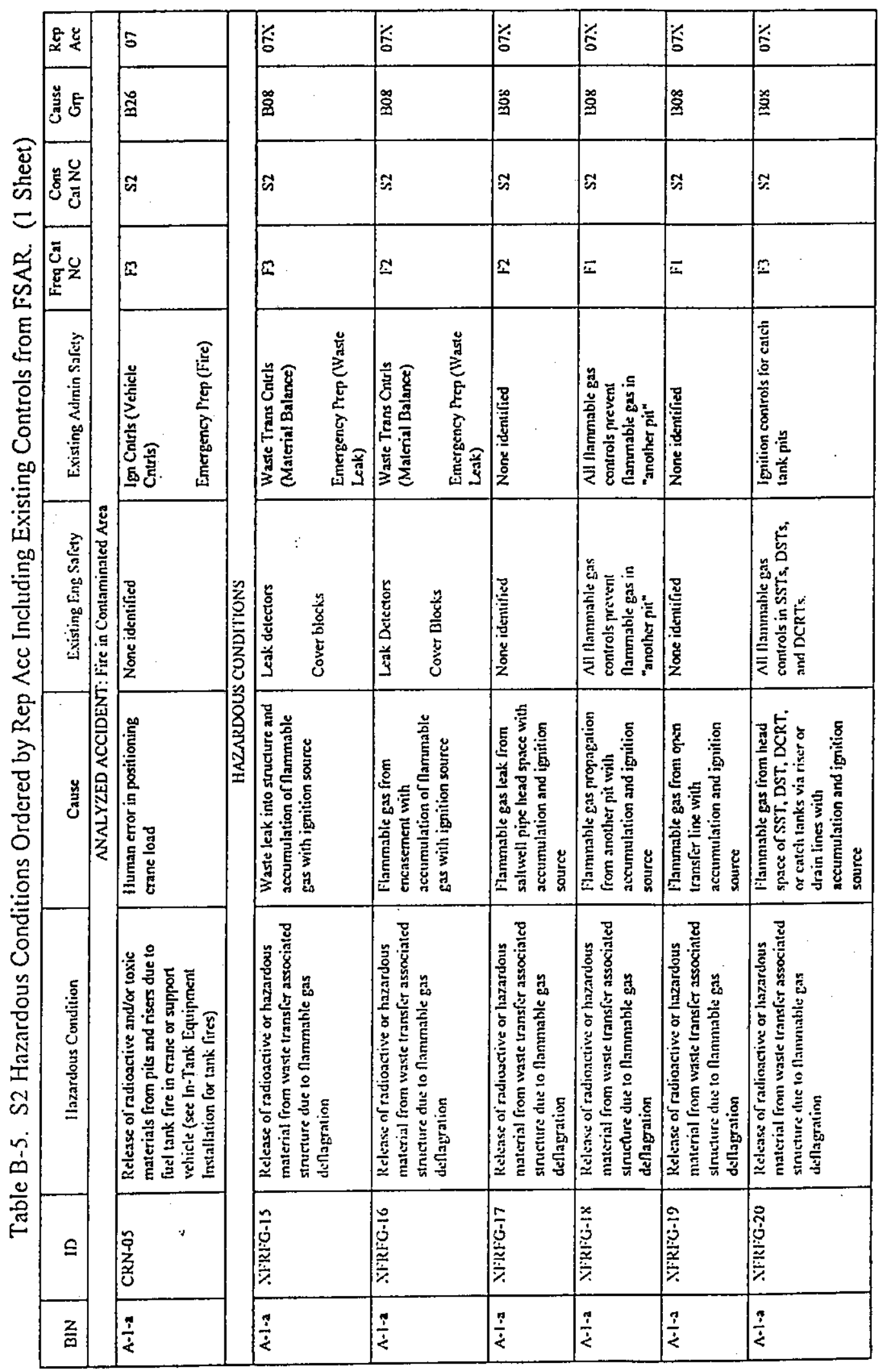

B5-1 


\section{RPP-5555 REV 0}

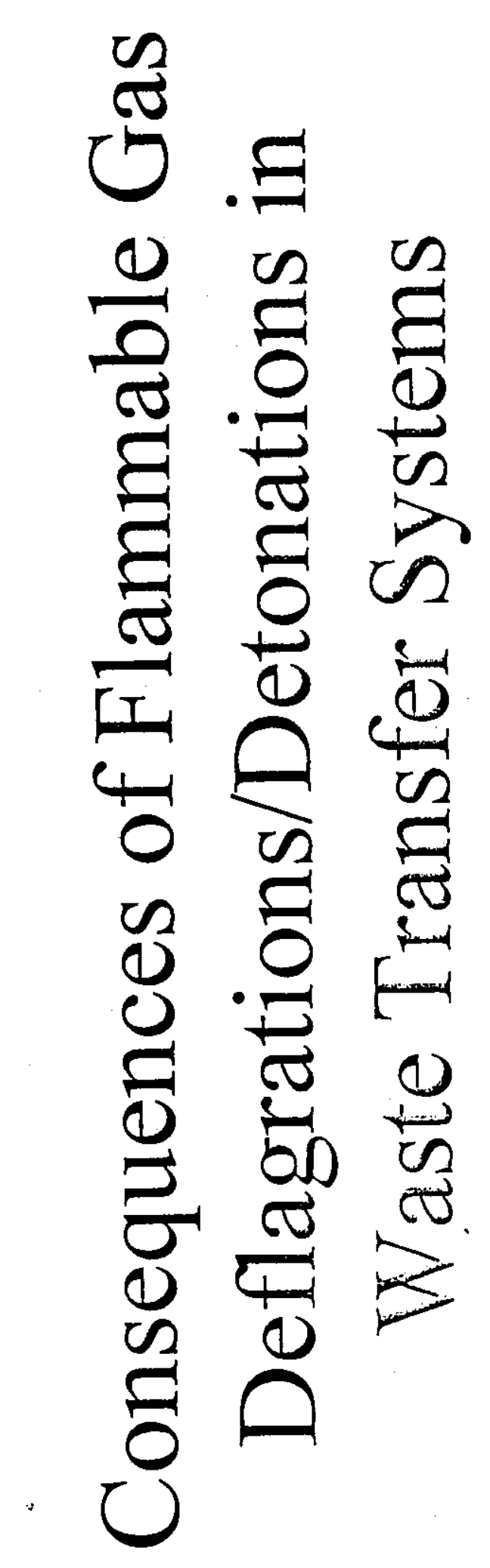

2

Att 4-19 


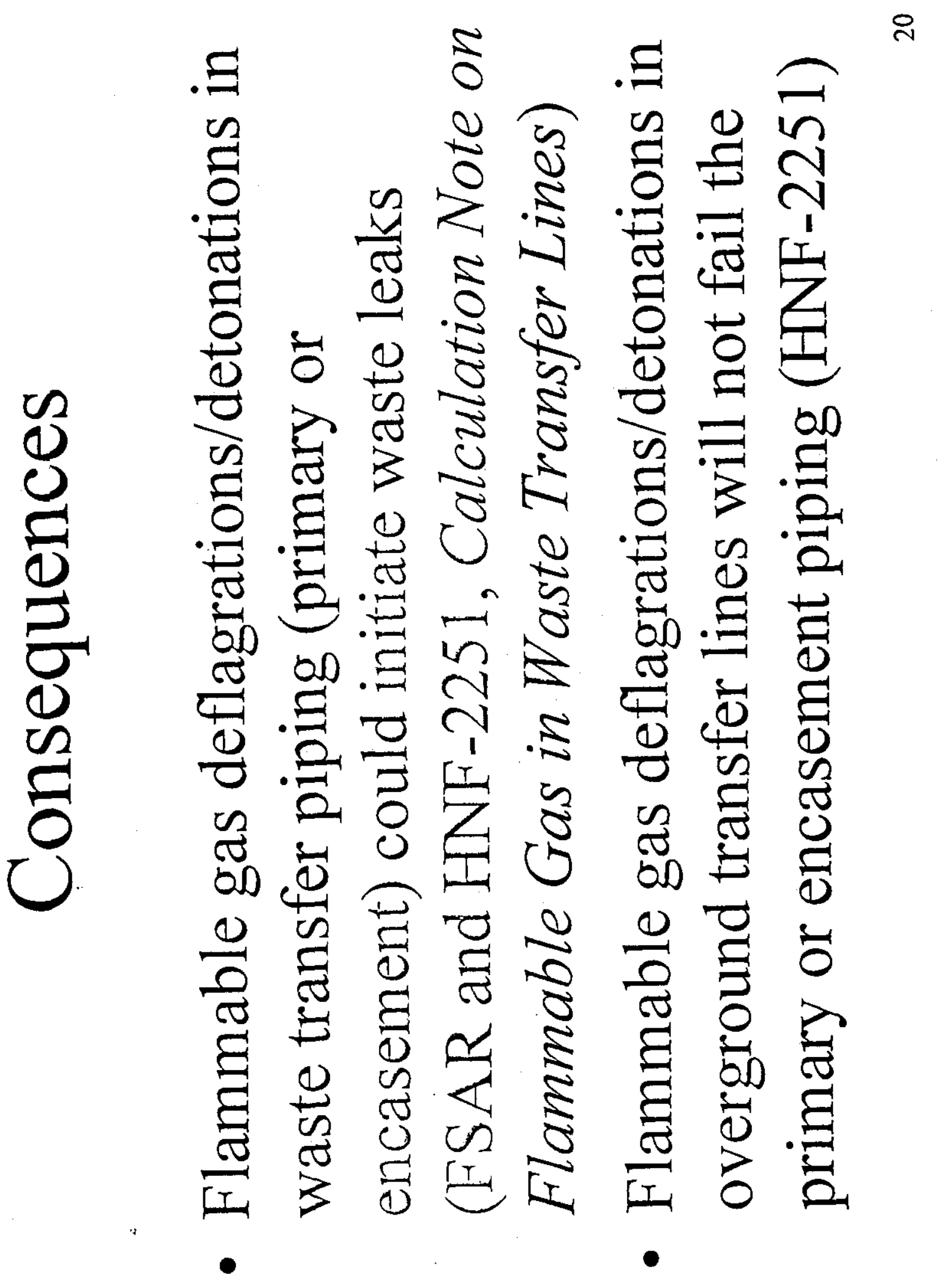




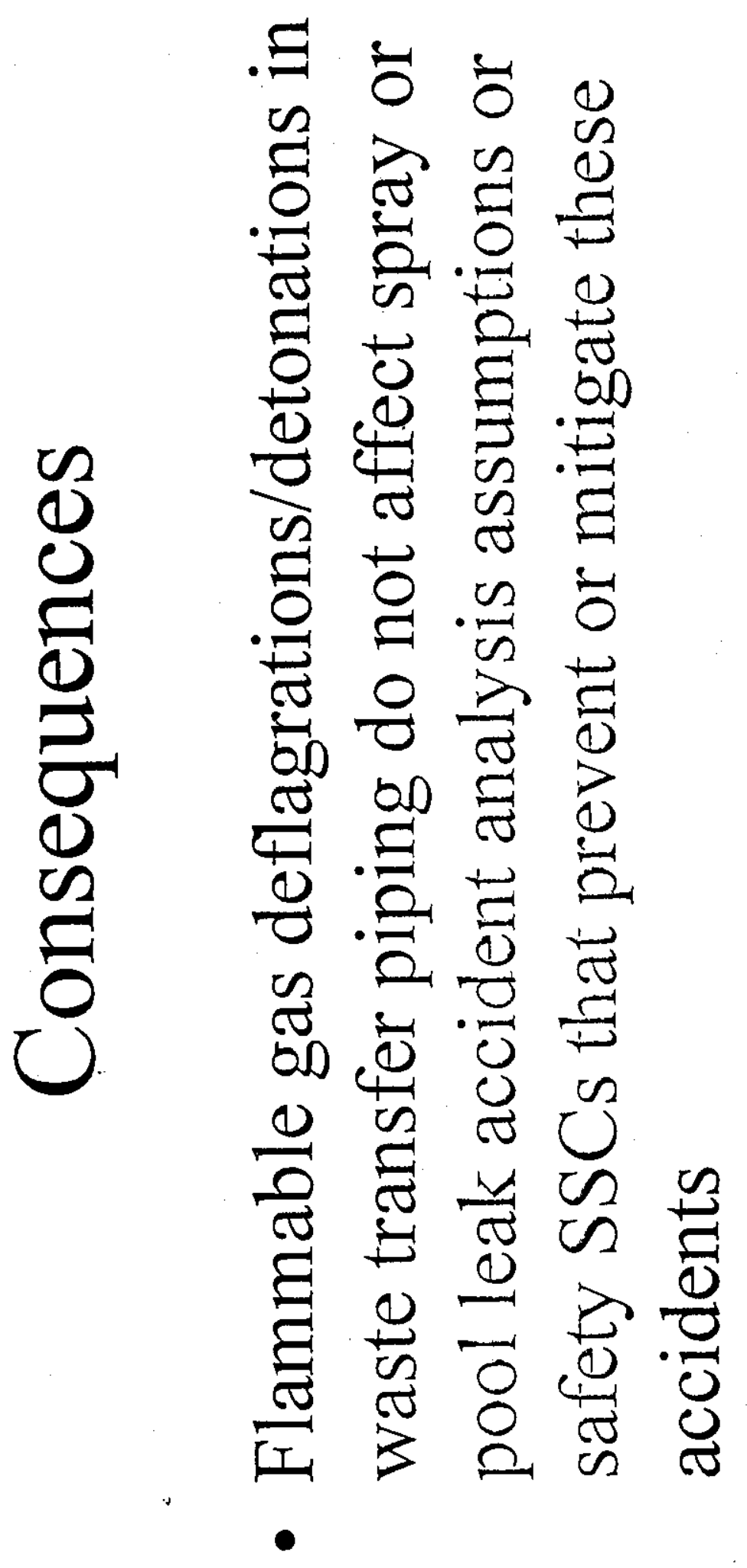




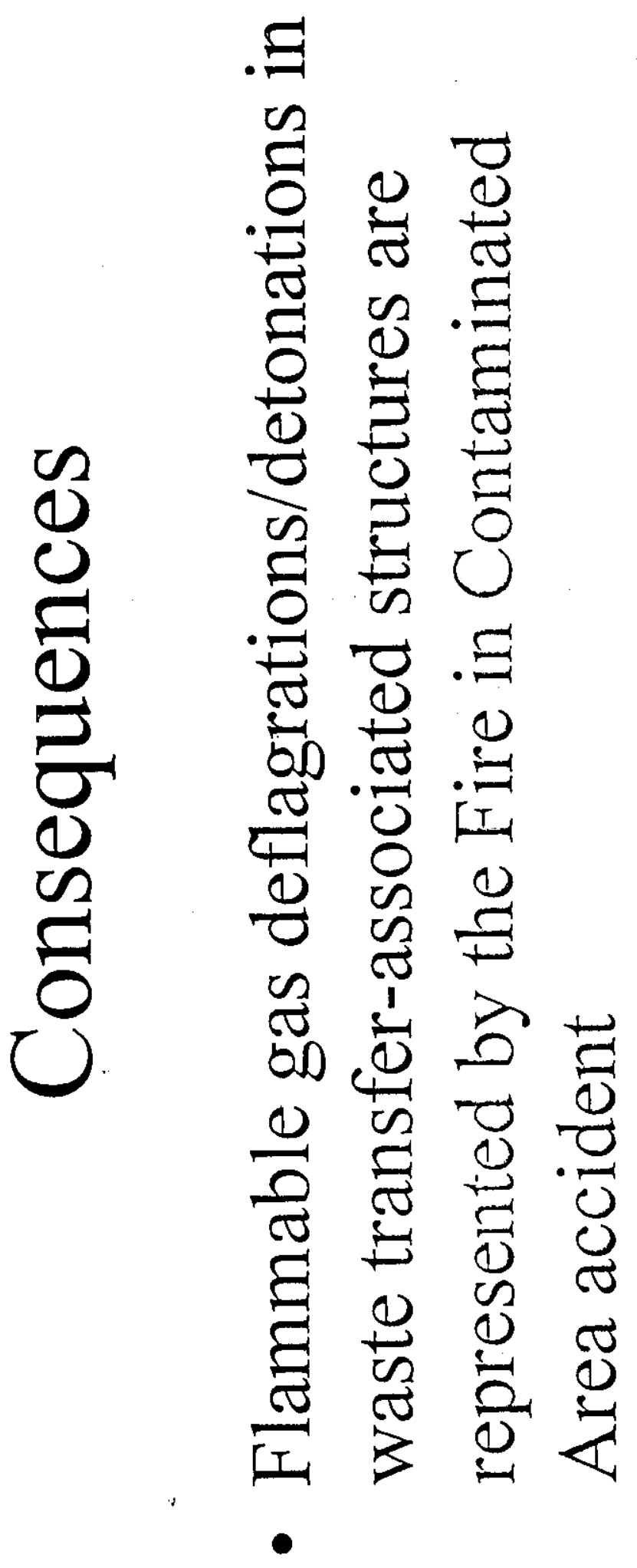

Att 4-22 
RPP-5555 REV 0

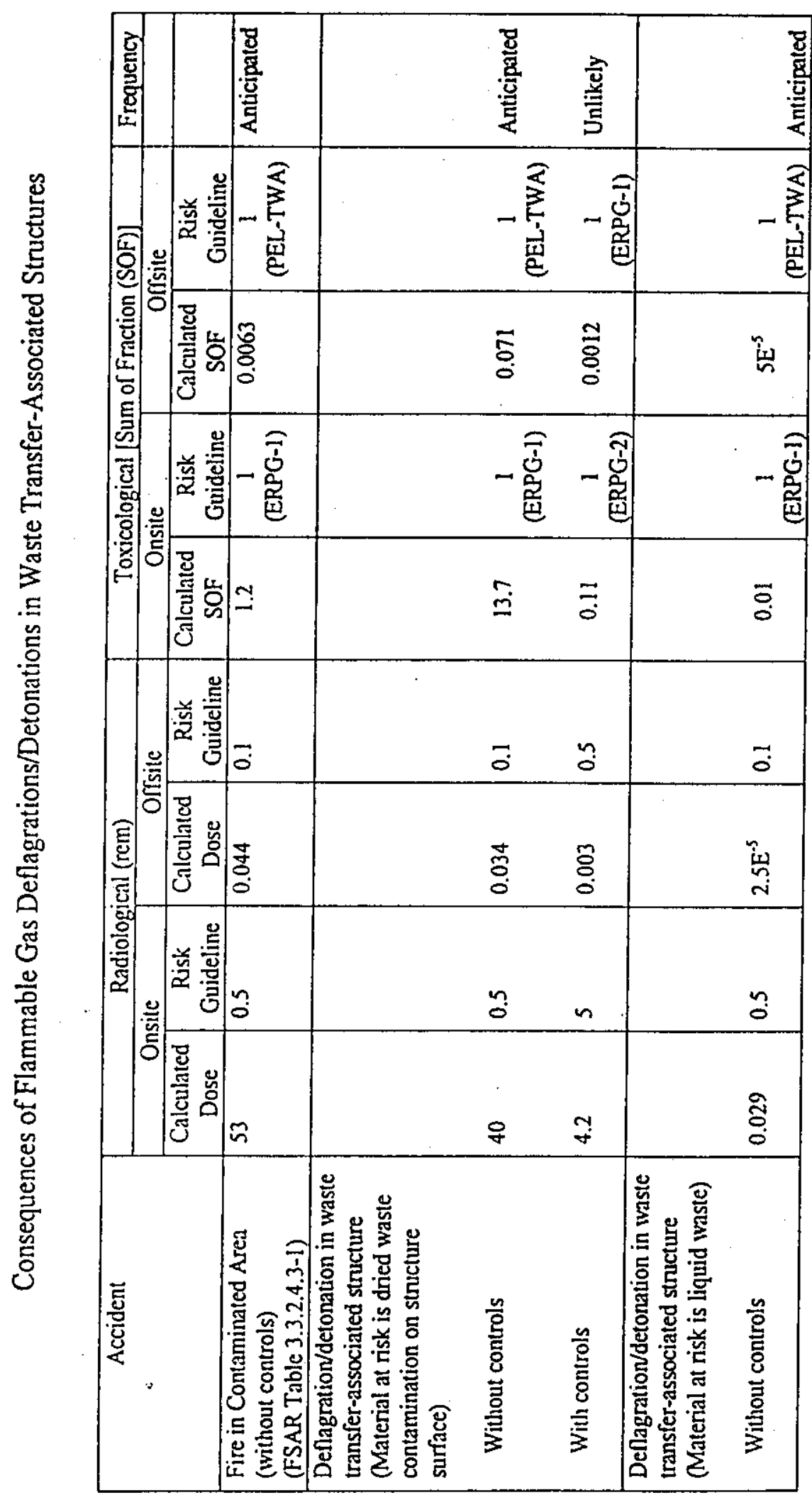

ข 
RPP-5555 REV 0

ম

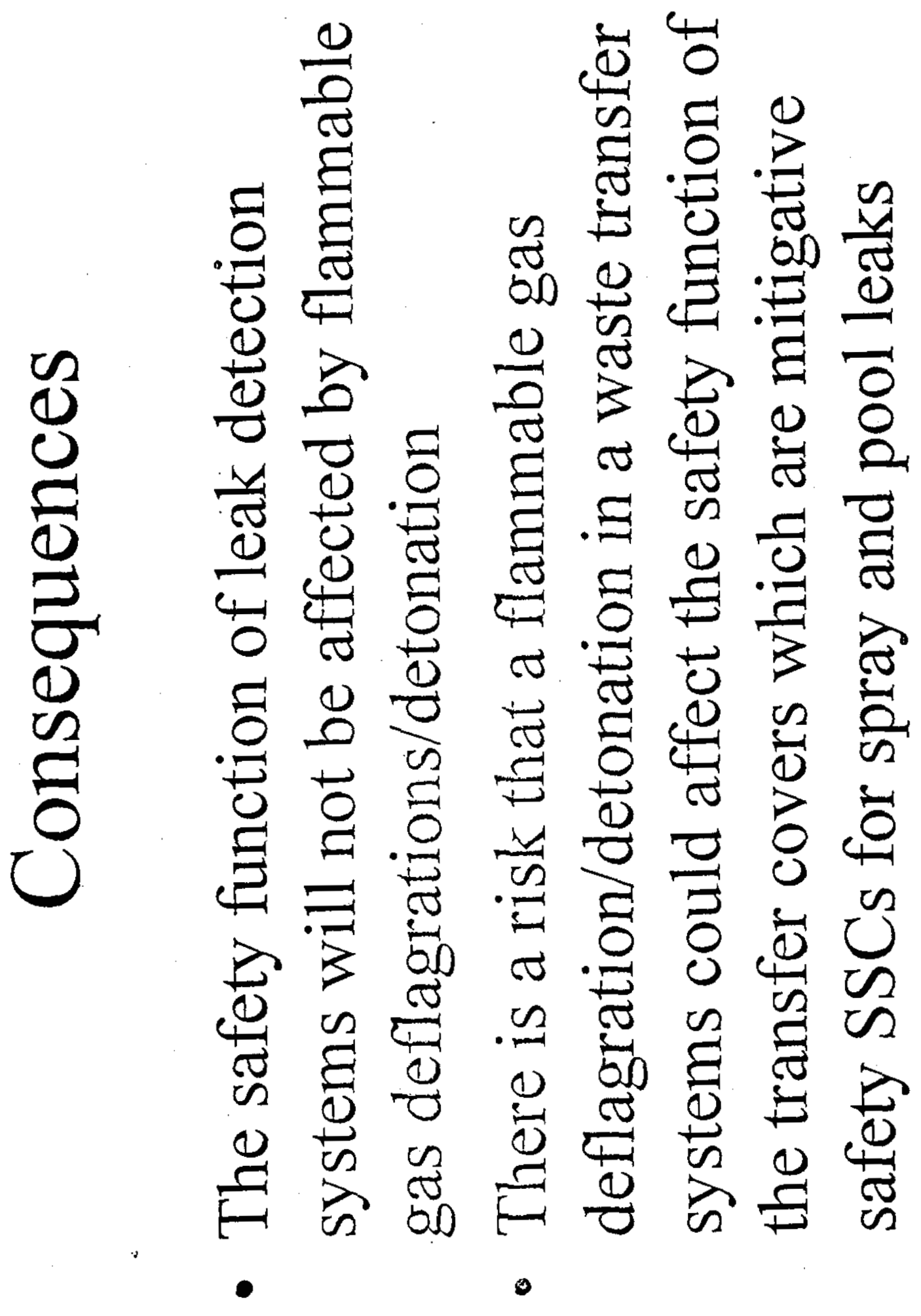


RPP-5555 REV 0

$\approx$
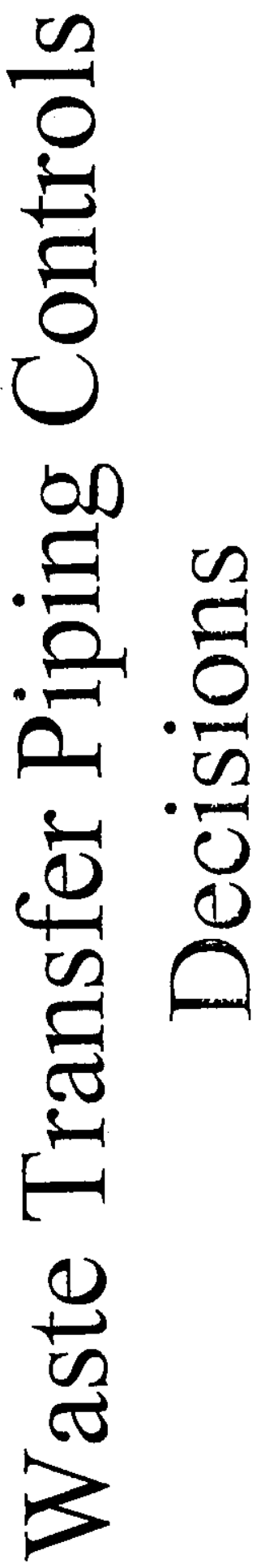

Att 4-25 


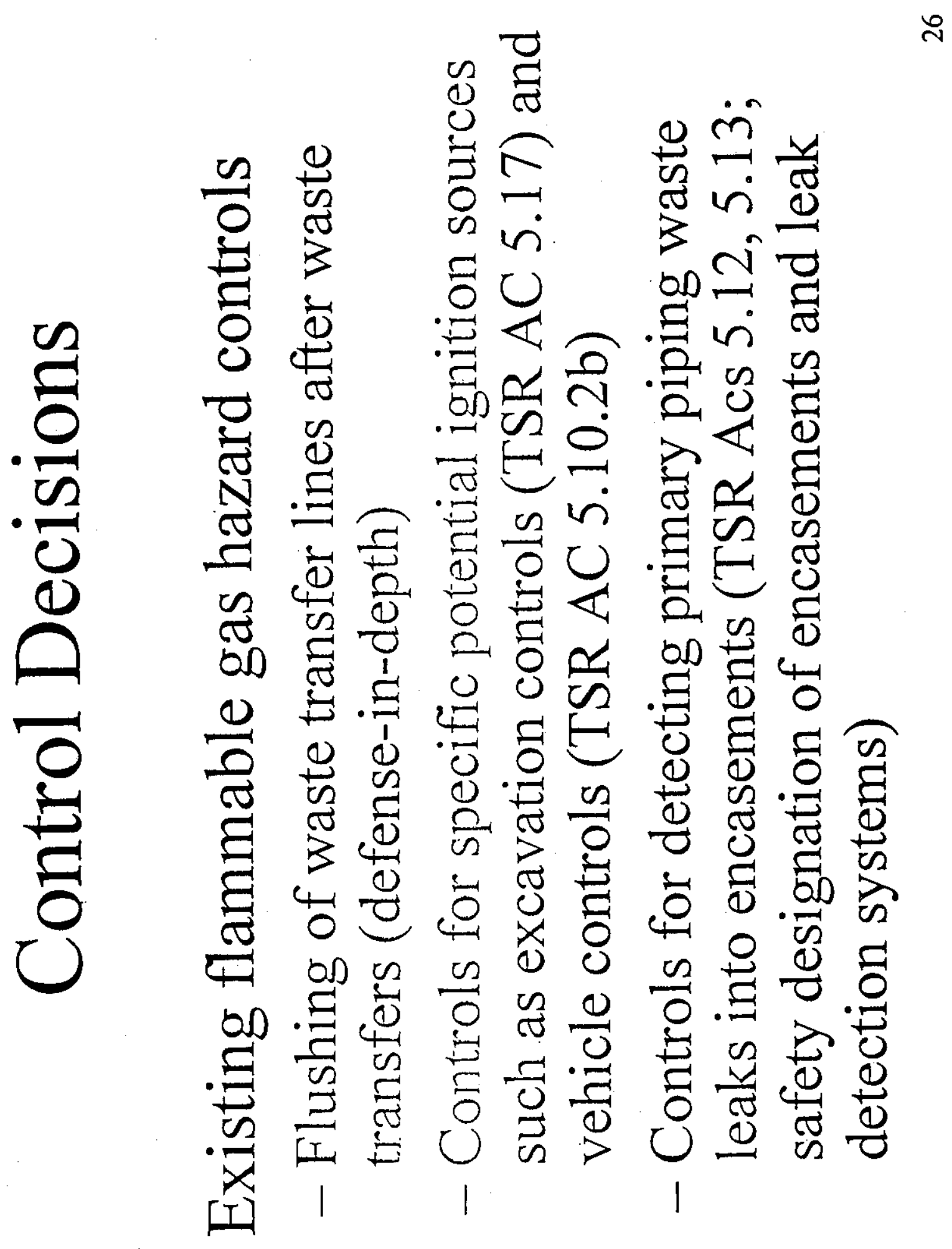




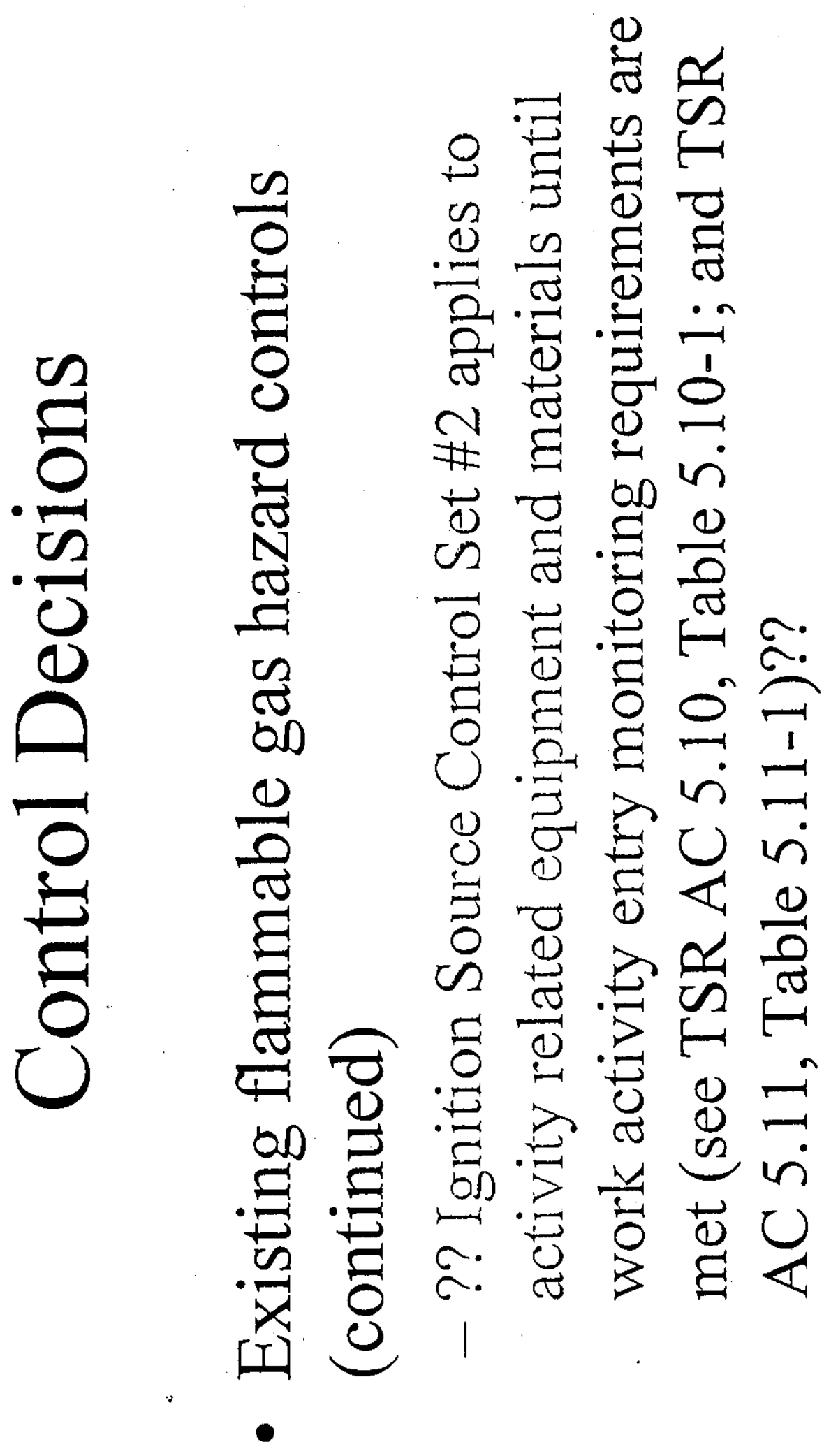


RPP-5555 REV 0

$\stackrel{\infty}{\sim}$

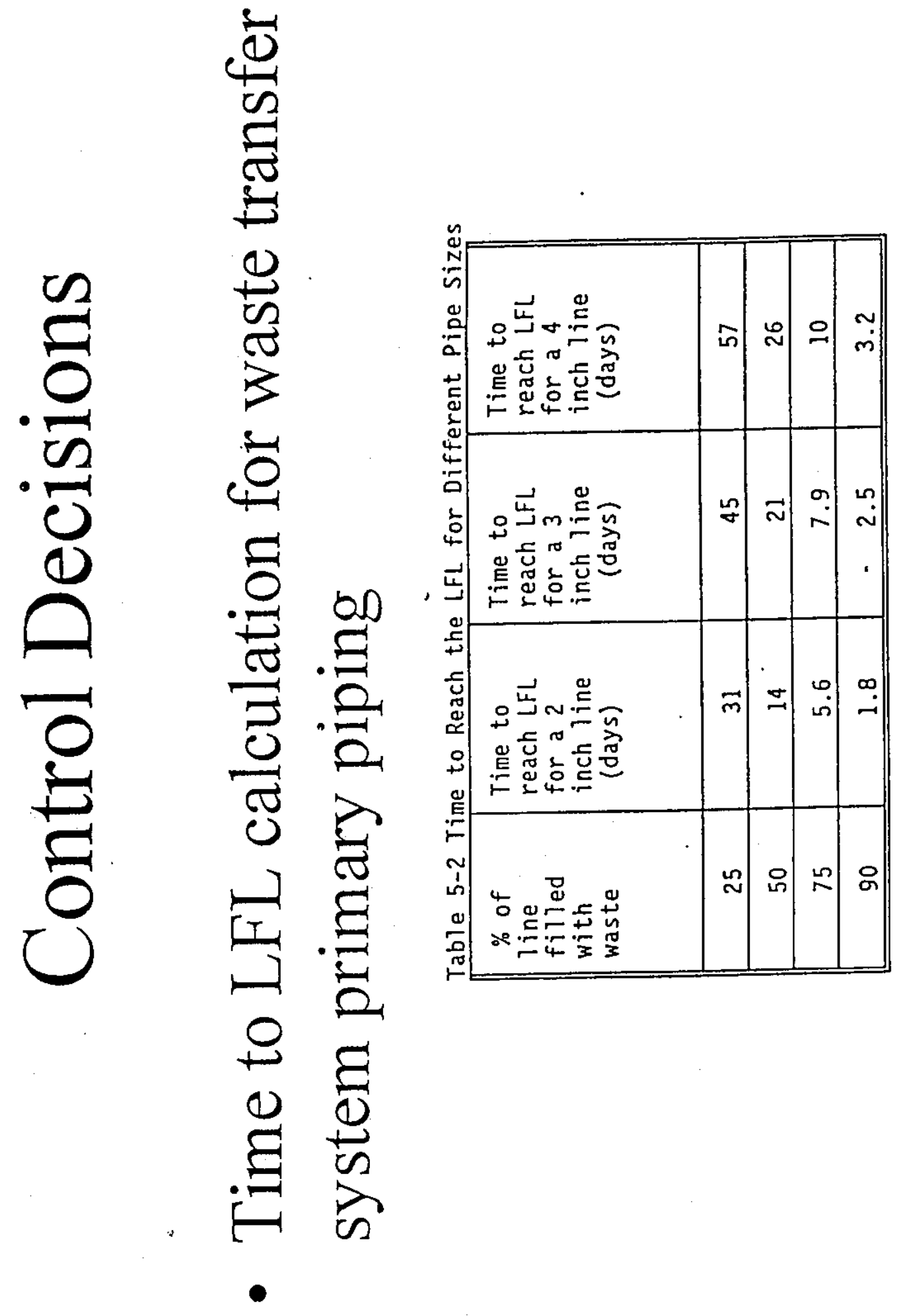


RPP-5555 REV 0

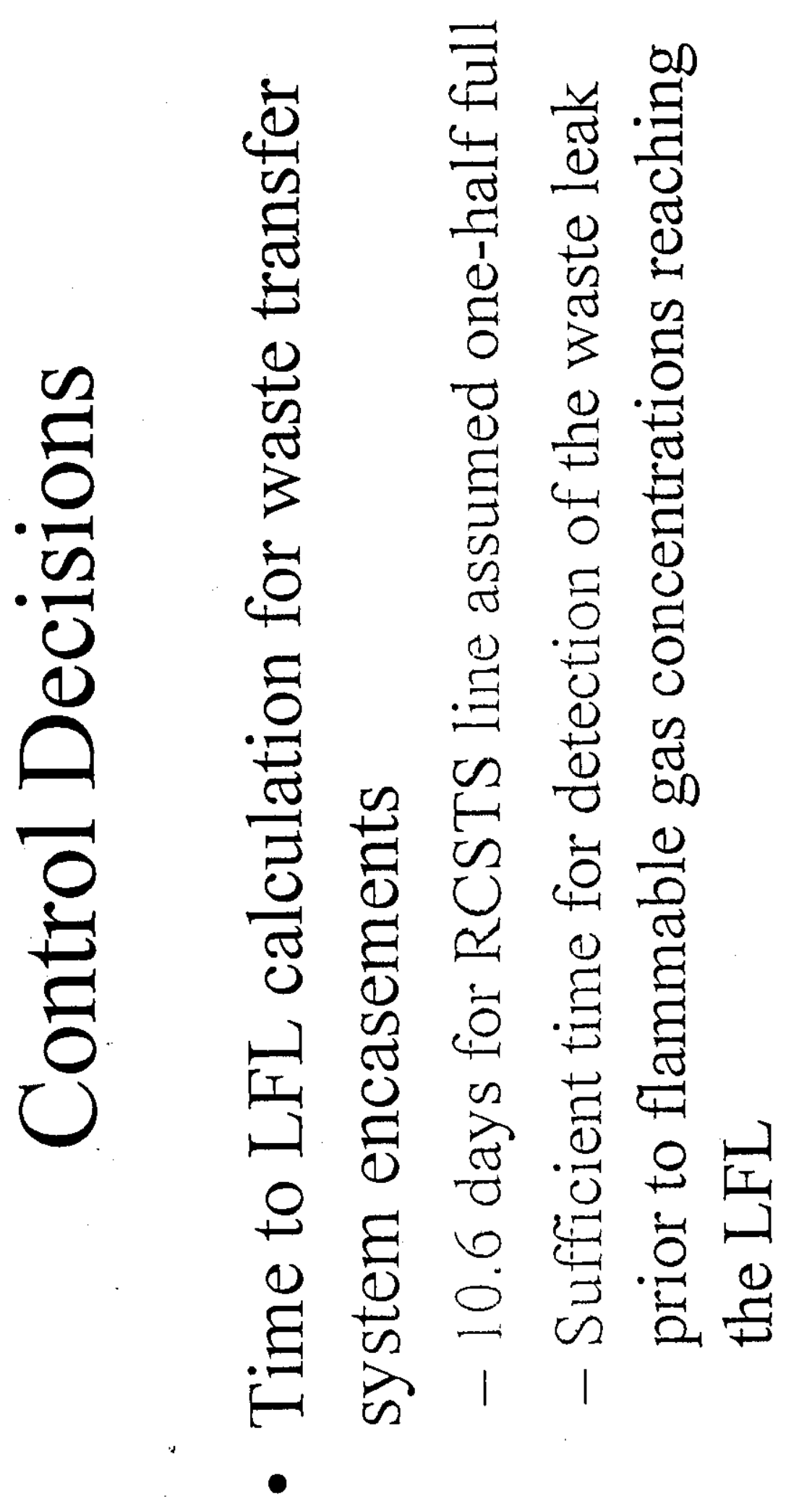




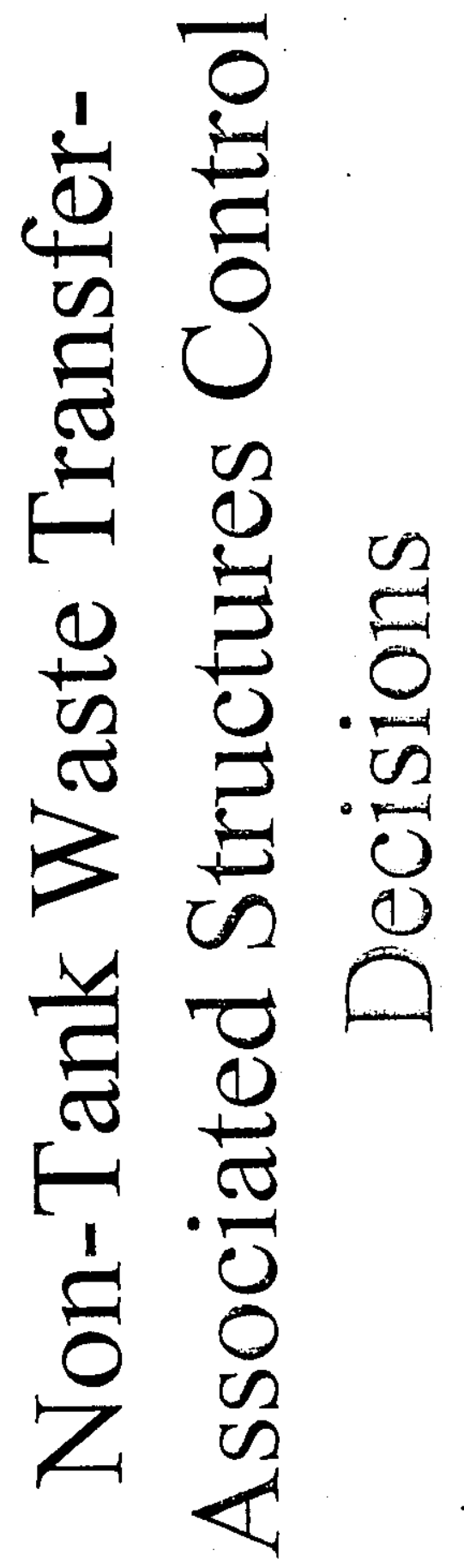

Att $4-30$ 


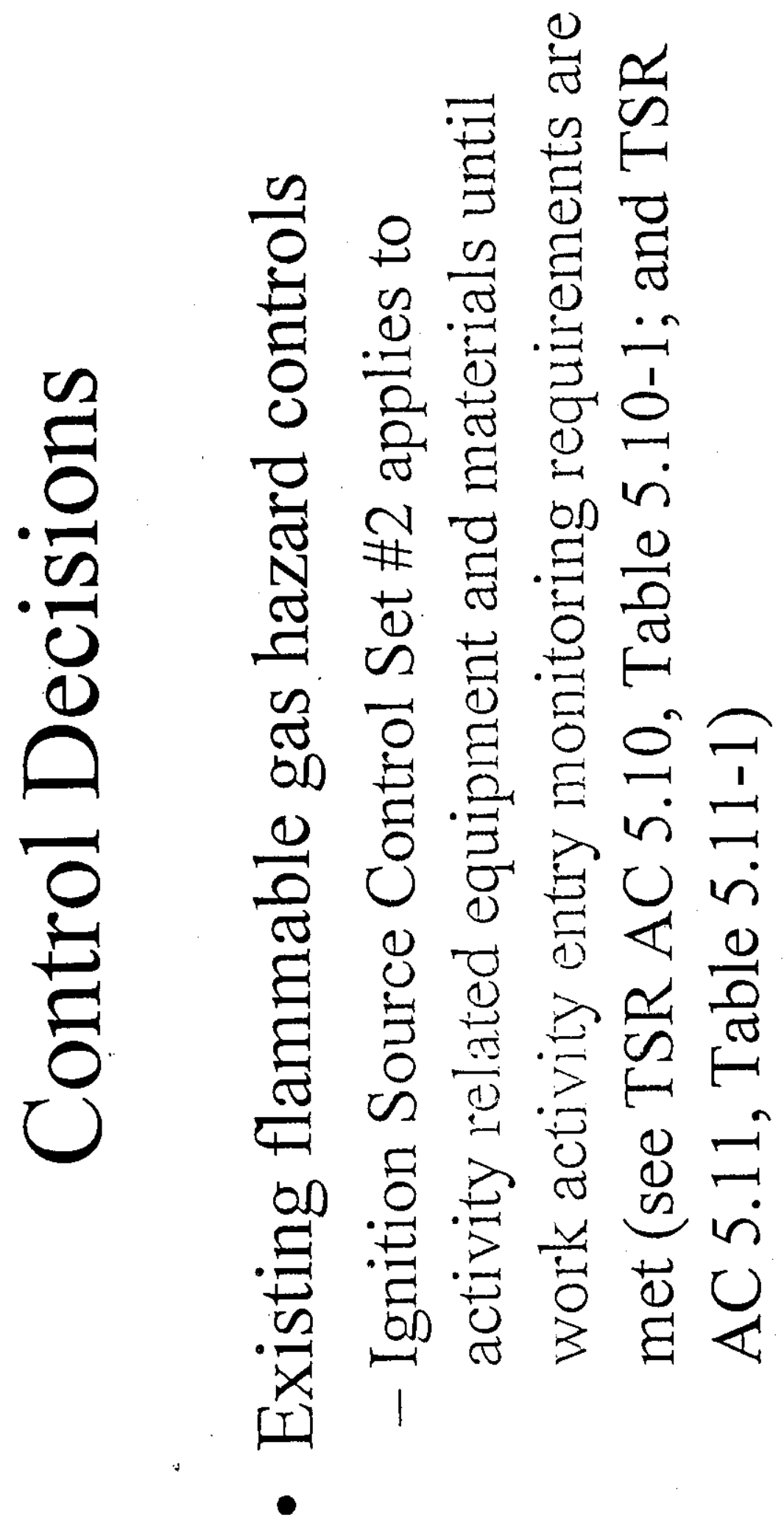




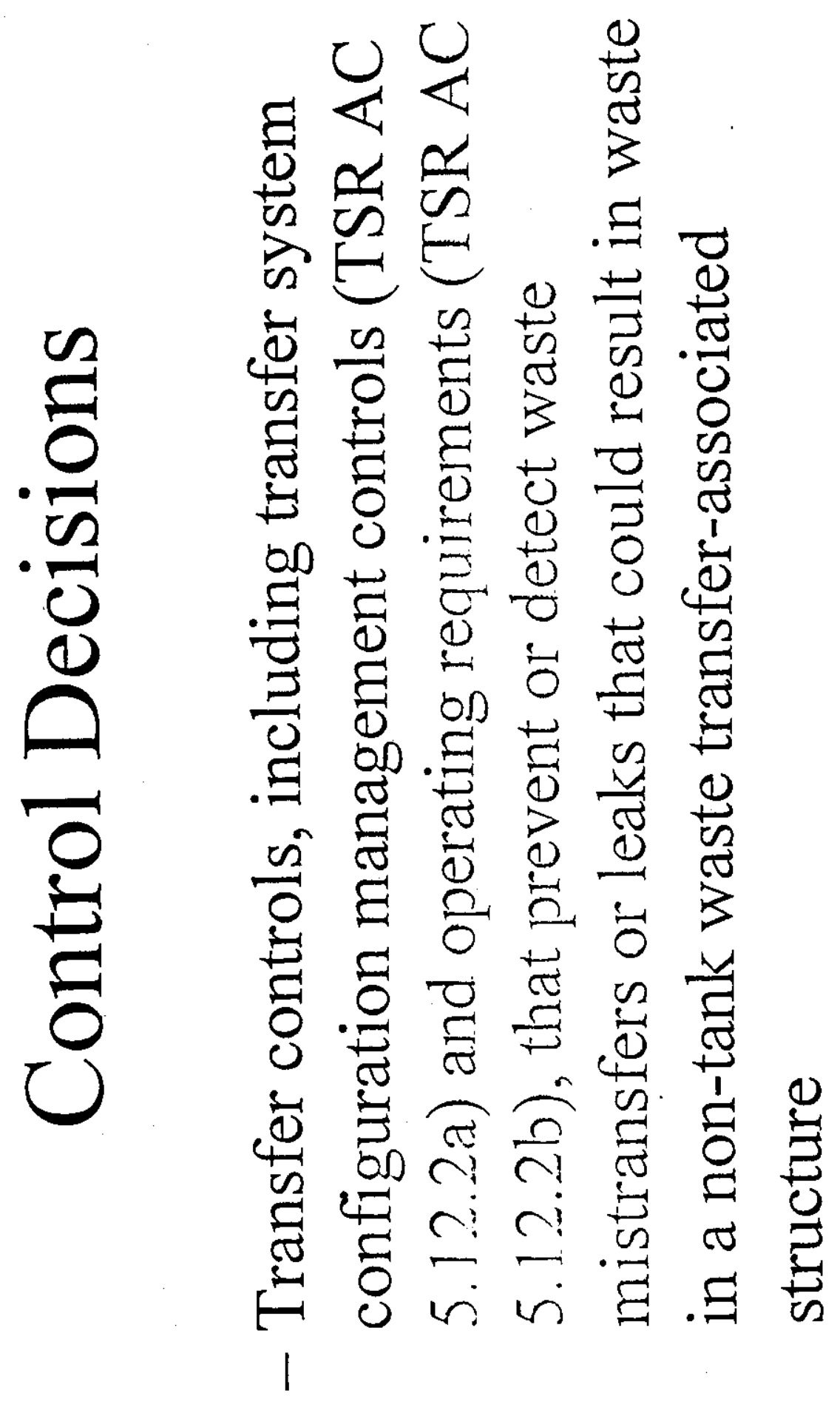


RPP-5555 REV 0

$m$

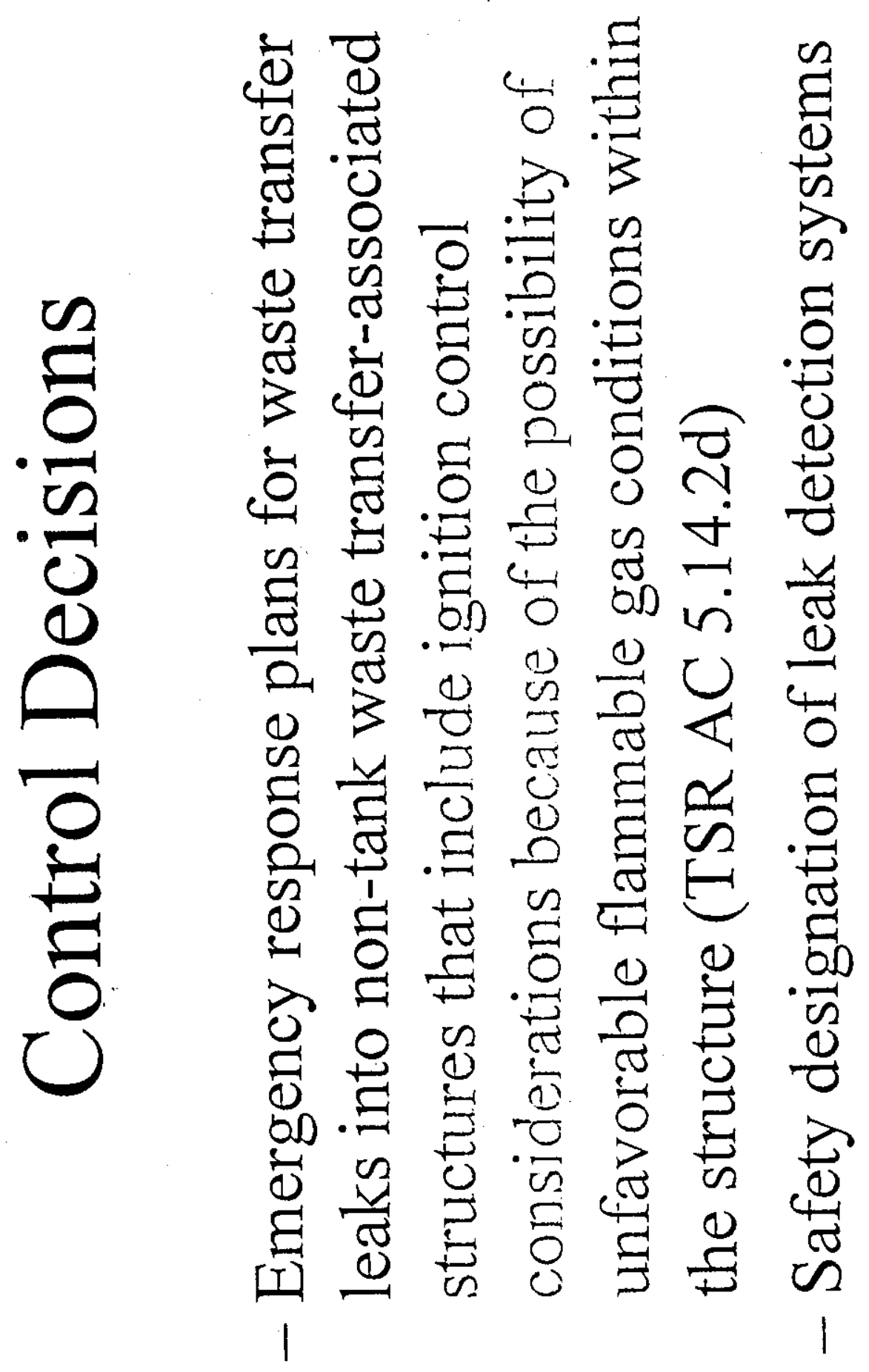

Att 4-33 


\section{RPP-5555 REV 0}

m

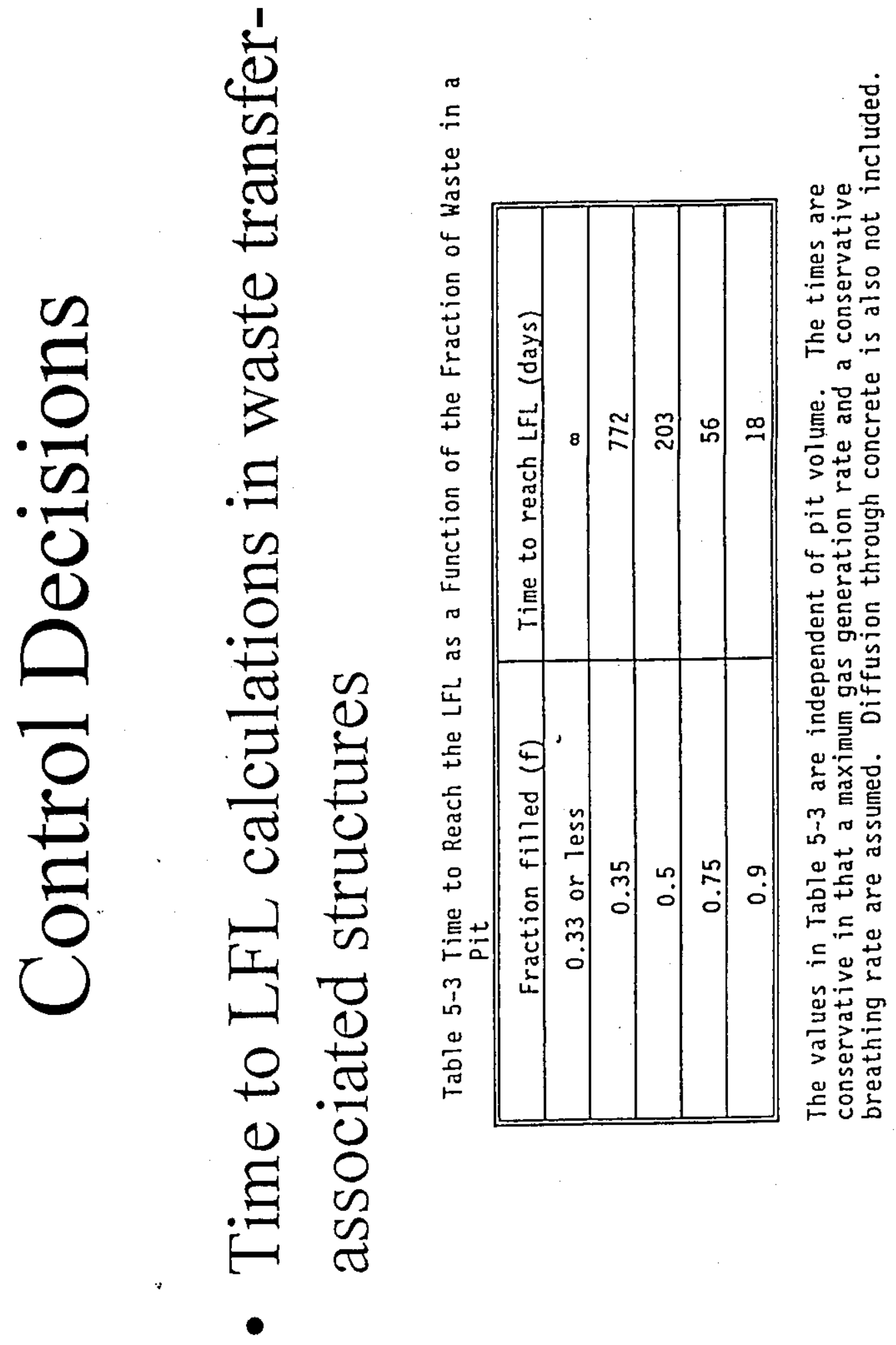

Att 4-34 


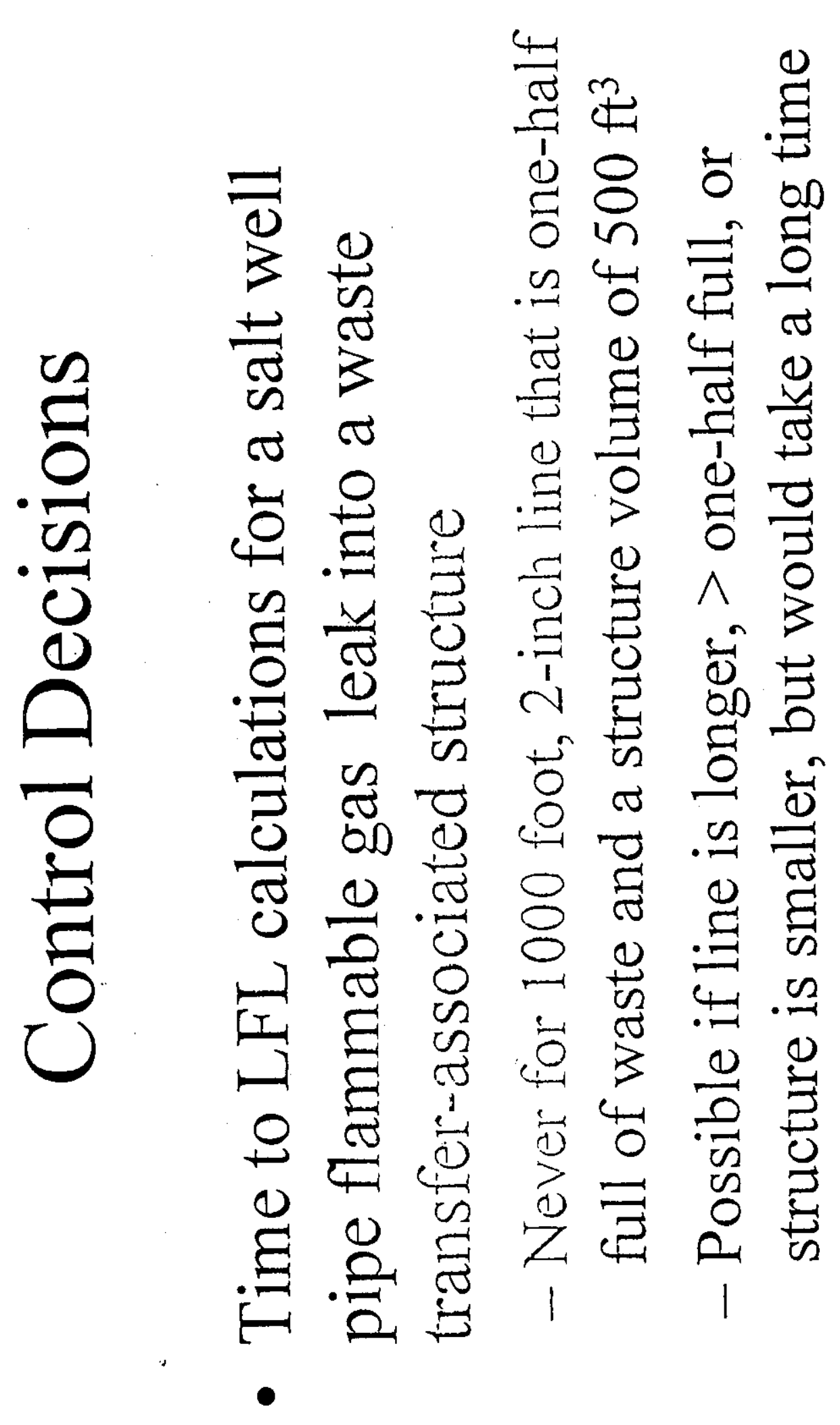




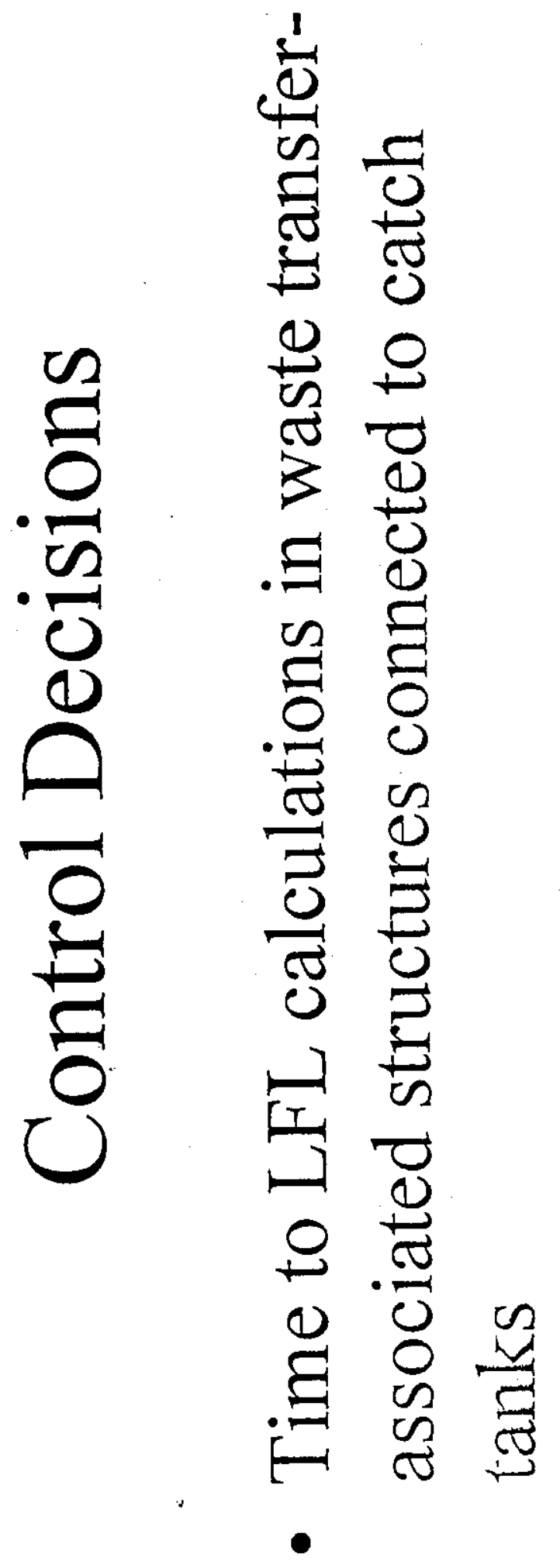

Att 4-36 


\section{RPP-5555 REV 0}

$m$

\begin{tabular}{|c|c|c|c|c|c|c|c|c|c|c|c|}
\hline 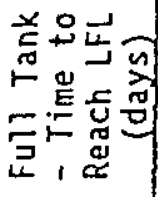 & $\dot{\square}$ & 8 & $\stackrel{n}{\vec{q}}$ & $\vec{\sim}$ & $\stackrel{\sim}{m}$ & $\dot{8}$ & $\stackrel{8}{\circ}$ & $\vec{\Xi}$ & के & $\begin{array}{l}\text { D } \\
\stackrel{\sim}{\sim}\end{array}$ & के \\
\hline 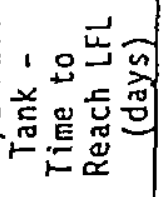 & $\stackrel{\bullet}{6}$ & B & $\vec{\sim}$ & $\overrightarrow{9}$ & $\stackrel{m}{\sim}$ & B & $\stackrel{m}{\stackrel{m}{二}}$ & $\tilde{n}$ & $\stackrel{2}{ \pm}$ & $\stackrel{g}{\stackrel{g}{二}}$ & $\stackrel{20}{=}$ \\
\hline 立 & 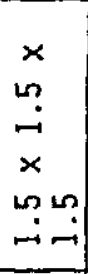 & $\begin{array}{l}\tilde{N} \\
\infty \\
\sim \\
\times \\
m \\
\times \\
m\end{array}$ & $\begin{array}{l}x \\
\dot{y} \\
\dot{n} \\
x \\
\dot{a} \\
\dot{\theta} \dot{m}\end{array}$ & $\begin{array}{l}x \\
\infty \\
\dot{-} \\
\times \\
\infty \\
\infty \\
\dot{i} \\
\end{array}$ & $\begin{array}{l}\times \\
\infty \\
\dot{-1} \\
\times \\
\infty \\
\dot{\sim} m \\
\dot{m}\end{array}$ & 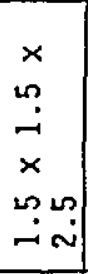 & 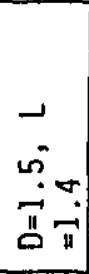 & \begin{tabular}{c|}
$\infty$ \\
$\dot{j}$ \\
$\dot{x}$ \\
$m$ \\
$\dot{m}$ \\
$m$ \\
$m$
\end{tabular} & 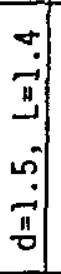 & $\begin{array}{l}n \\
\ddot{n} \\
\ddot{n} \\
\ddot{n} \\
\ddot{n}\end{array}$ & $\begin{array}{c}+ \\
0 \\
n \\
4 \\
0 \\
0 \\
0 \\
0\end{array}$ \\
\hline 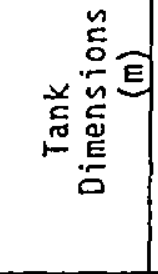 & $\begin{array}{l}m \\
\text { in } \\
11 \\
m \\
m \\
0\end{array}$ & 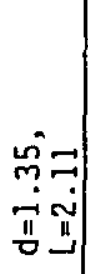 & $\begin{array}{ll}5 & -1 \\
0 & 0 \\
0 & 0\end{array}$ & \begin{tabular}{l|l}
$x$ \\
$\infty$ \\
$\dot{v}$ \\
$\times$ \\
$\infty$ \\
$\infty$ & $n$ \\
$\dot{\omega}$ & $m$
\end{tabular} & $\begin{array}{c}x \\
\infty \\
\dot{-} \\
\times \\
\dot{m} \\
\dot{m} \\
\dot{m}\end{array}$ & 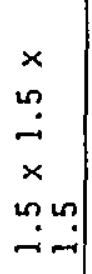 & 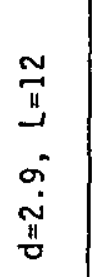 & \begin{tabular}{l|}
0 \\
$\dot{0}$ \\
-1 \\
-1 \\
0 \\
0
\end{tabular} & 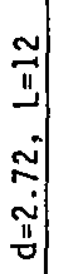 & $\begin{array}{l}0 \\
\text { it } \\
0 \\
0 \\
0\end{array}$ & 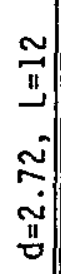 \\
\hline 总惫 & 离 & $\begin{array}{l}\vec{\sigma} \\
\text { N }\end{array}$ & $\tilde{\sigma}$ & $\stackrel{\varphi}{\dot{\sigma}}$ & $\stackrel{n}{8}$ & $\stackrel{\text { I }}{\text { m. }}$ & $\hat{0}$ & $\begin{array}{l}\infty \\
\grave{\sim}\end{array}$ & $\begin{array}{l}0 \\
\vdots \\
0\end{array}$ & $\begin{array}{l}n \\
m \\
m\end{array}$ & $\begin{array}{l}0 \\
\dot{0} \\
0\end{array}$ \\
\hline 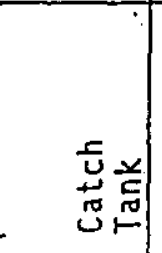 & 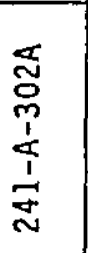 & 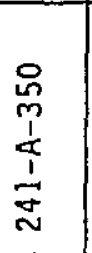 & 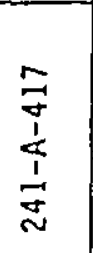 & 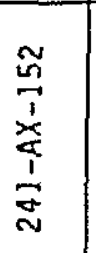 & $\begin{array}{l}\vec{n} \\
\frac{1}{d} \\
\frac{\pi}{1} \\
\frac{\vec{N}}{N}\end{array}$ & 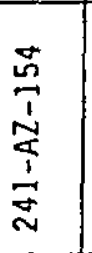 & 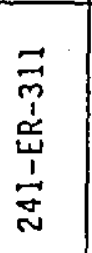 & 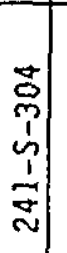 & 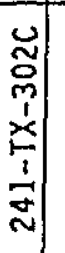 & $\begin{array}{l}\infty \\
\frac{a}{9} \\
\\
1 \\
1 \\
\frac{1}{N}\end{array}$ & 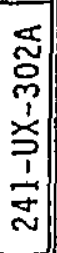 \\
\hline
\end{tabular}


RPP-5555 REV 0

$\infty$

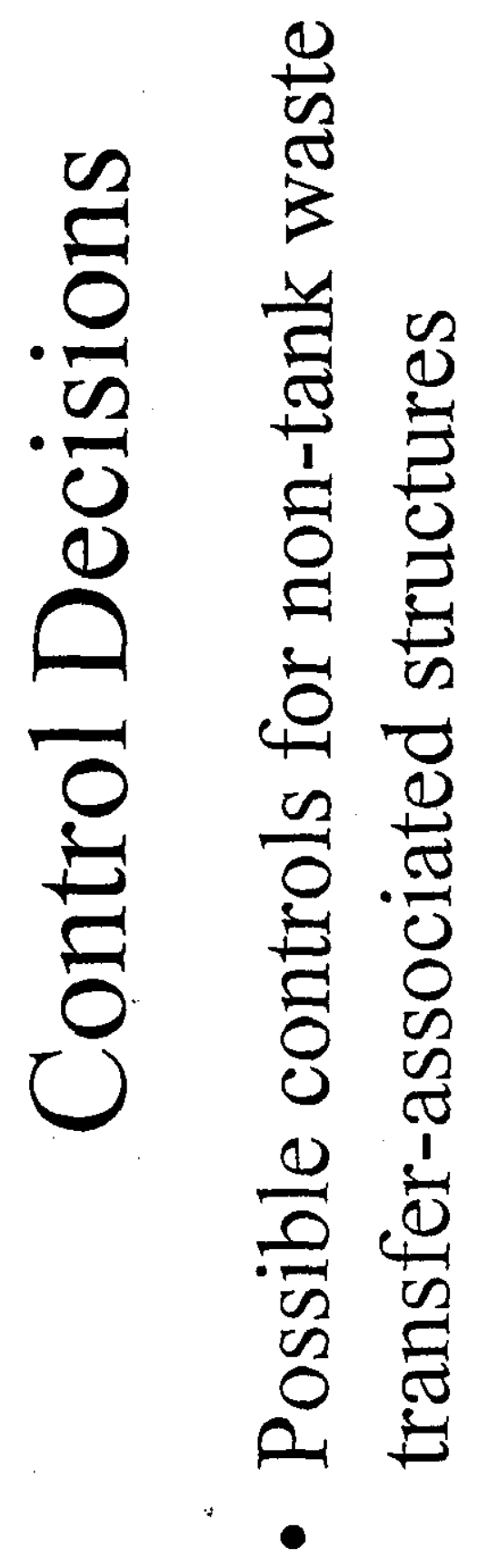

Att 4-38 
RPP-5555 REV 0

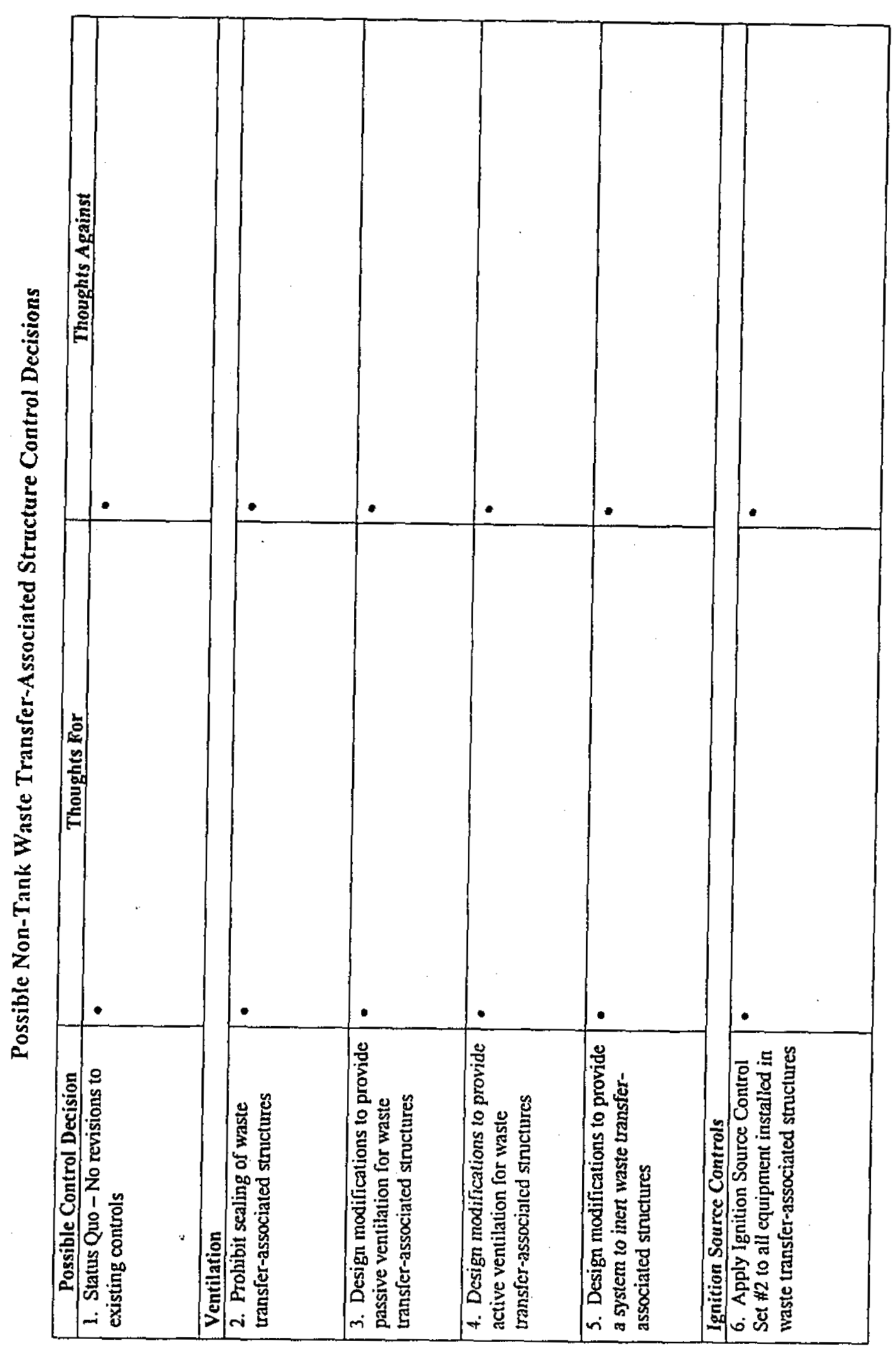

Att 4-39 


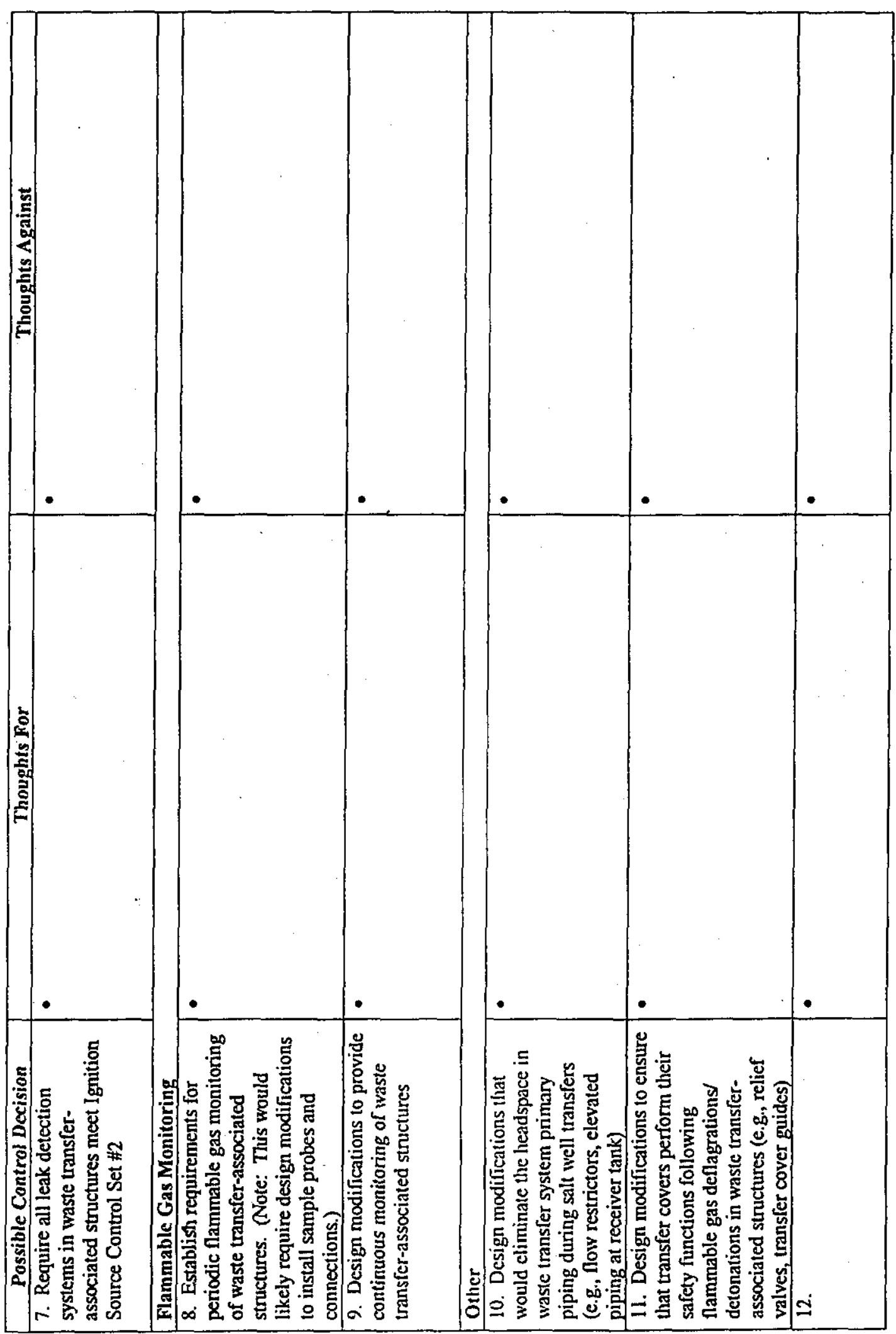

Att 4-40 
RPP-5555 REV 0

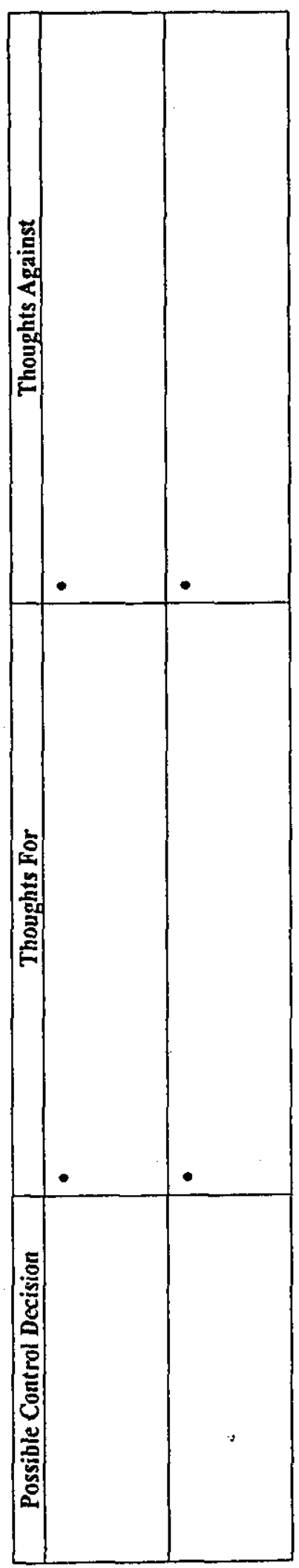

Att 4-41 
RPP-5555 REV 0

This page intentionally left blank.

Att 4-42 


\section{RPP-5555 REV 0}

\section{ATTACHMENT 5}

CONTROL DECISION MEETING ON APRIL 19, 2000 TO ADDRESS FLAMMABLE GAS HAZARDS IN DCRTS AND WASTE TRANSFER SYSTEMS 


\section{RPP-5555 REV 0}

This page intentionally left blank.

Att 5-ii 


\section{RPP-5555 REV 0}

\section{ATTACHMENT 5 - PART 1}

AGENDA FOR CONTROL DECISION MEETING ON APRIL 19, 2000 TO ADDRESS FLAMMABLE GAS HAZARDS IN DCRTS AND WASTE TRANSFER SYSTEMS

Att 5-1 
Agenda for Control Decision Meeting on April 19, 2000 To Address

Flammable Gas Hazards in DCRTs and Waste Transfer Systems

April 19. 2000 (Wednesday)

Note: All times are estimates and may vary.

1:00- 1:15 Introduction
A. Purpose
B. Scope
C. Process

1:15-1:45 New and Revised Accident Analyses

A. Revised frequencies and consequences of flammable gas deflagrations and detonations in DCRTs and the effect on the classification of safety SSCs (i.e., DCRT ventilation systems)

B. Estimated consequences of flammable gas deflagrations in RCSTS diversion box $6241-\mathrm{A}$ and vent station $6241-\mathrm{V}$ and the effect on the classification of safety SSCs (e.g., leak detection systems)

\section{1:45-2:15 New and Revised Predictions of Flammable Gas Concentrations}

A. Revised predictions for DCRTs 244-A, 244-BX, 244-S, 244-TX, and 244-U

B. New predictions for 244-CR Vault Tank 003 to support interim stabilization of the vault and the need for controls

C. New predictions for waste leaks into the DCRT vaults and the need for controls

\section{2:15-2:30 Break}

2:30-3:00 Draft LCO 3.2.4, DCRT Ventilation Systems (i.e., air supply flow rate, required actions and completion times, surveillance frequencies)

\section{3:00-3:15 Draft AC 5.9}

A. Waste transfer-associated structure ventilation control

B. Waste transfer prohibitions

3:15-4:00 Draft AC 5.11.2d, DCRT (Flammable Gas Monitoring) Controls

A. Continuous monitoring during salt well pumping

B. Periodic monitoring

4:00-4:30 Summary 
RPP-5555 REV 0

ATTACHMENT 5 - PART 2

ATTENDANCE RECORD OF CONTROL DECISION MEETING FOR FLAMMABLE GAS HAZARDS IN DCRTS AND WASTE TRANSFER SYSTEMS ON APRIL 19, 2000

Att 5-3 
RPP-5555 REV 0

Attendance Record of Control Decision Meeting for Flammable Gas Hazards in CRTs and Waste Transfer Systems on April 19, 2000

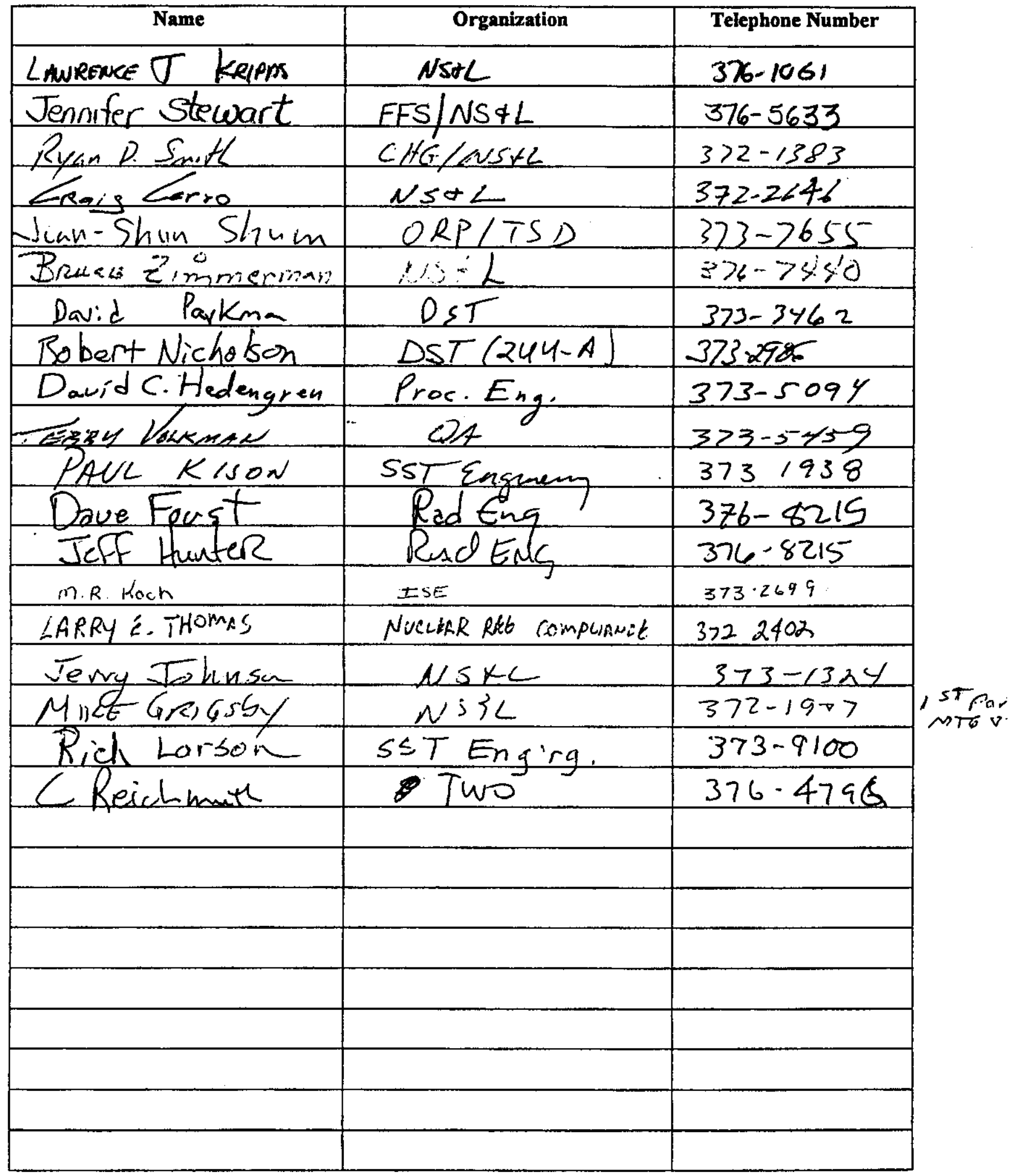

Att 5-4 


\section{RPP-5555 REV 0}

\section{ATTACHMENT 5 - PART 3}

PURPOSE, SCOPE, AND PROCESS FOR CONTROL DECISION MEETING TO ADDRESS DCRT AND WASTE TRANSFER SYSTEM FLAMMABLE GAS HAZARDS 


\section{CONTROL DECISION MEETING TO ADDRESS DCRT AND WASTE TRANSFER SYSTEM FLAMMABLE GAS HAZARDS}

Note: Controls include safety-class and safety-significant structures, systems, and components (SSCs); technical safety requirements (TSRs); and other controls that provided defense-in-depth or environmental protection.

\section{Purpose:}

The purpose of the control decision meeting is to review and revise previously selected controls for the prevention or mitigation of flammable gas hazards in double-contained receiver tanks (DCRTs) and waste transfer systems. The control decision meeting is needed to consider new and revised analyses since the November 16,17, and 18, 1999 control decision meetings for DCRTs and the November 30, 1999 control decision meeting for waste transfer systems. The control decisions and their basis support the closure of the Flammable Gas Unreviewed Safety Question (USQ) for DCRTs and waste transfer systems.

\section{Scope:}

The scope of the control decision meeting covers potential flammable gas hazards in DCRTs (i.e., 244-A, 244-BX, 244-S, 244-TX, 244-U, and 244-CR Vault Tank 003) and in waste transfer systems (i.e., waste transfer piping and waste transfer-associated structures).

\section{Process:}

The control decision process and the criteria for control decisions are described in the FSAR (HNF-SD-WM-SAR-067) along with the methodology for the hazard and accident analyses whose results are used to identify controls. Control decision criteria are summarized in Attachment I.

Control decisions will be based on the best available information from the hazard and accident analyses and on the technical expertise and experience of the meeting participants. Decisions will be made by consensus.

Required participants in the DCRT and waste transfer system flammable gas hazard control decision meeting are representatives from operations, engineering (including SST and DST Design Authority and cognizant engineers), interim stabilization, process engineering, and nuclear safety and licensing. Control decision meeting participants may also include representatives from waste retrieval, nuclear regulatory compliance support, radiological control, safety and emergency preparedness, environmental, and quality assurance. Personnel responsible for developing the information or performing the analysis supporting control decisions will be present at the control decision meeting. U.S. Department of Energy (DOE) Office of River Protection (ORP) staff have been invited to observe the control decision meeting.

The control decision meeting discussions will be documented, including the control decisions (see Attachment II). This documentation will be included or referenced in an amendment to 
the Authorization Basis (i.e., FSAR and TSRs) containing the proposed basis and control revisions to close the Flammable Gas USQ for DCRTs and waste transfer systems. DOE review and approval of the Authorization Basis amendment will be required. 


\section{SUMMARY OF CONTROL DECISION CRITERIA}

Note: FSAR Section 3.3.1.5, "Controls Identification," contains a complete discussion of control decision criteria.

\section{Control decision criteria are based on the following documents}

DOE 5480.23, Nuclear Safety Analysis

DOE 5480.22, Technical Safety Requirements

DOE-STD-3009-94, Preparation Guide for U.S. Department of Energy Nonreactor Nuclear Facility Safety Analysis Reports

WHC-CM-4-46, Nonreactor Facility Safety Analysis Manual, Section 6, "Technical Safety Requirements," Rev. 1, and Section 9, "Safety Classification of Structures, Systems, and Components,: Rev. 2.

Risk Evaluation Guidelines:

$\underline{\text { Radiological Risk Guidelines }}$

\begin{tabular}{|l|c|c|c|}
\hline \multirow{2}{*}{ Frequency category } & Frequency range (yr-1) & \multicolumn{2}{|c|}{ Effective dose equivalent (rem) } \\
\cline { 3 - 4 } & & Onsite & Offsite \\
\hline Anticipated & $>10^{-2}$ to $\leq 10^{0}$ & 0.5 & 0.1 \\
\hline Unlikely & $>10^{-4}$ to $\leq 10^{-2}$ & 5 & 0.5 \\
\hline Extremely unlikely & $>10^{-6}$ to $\leq 10^{-4}$ & 10 & 4 \\
\hline
\end{tabular}

Toxicological Risk Guidelines

\begin{tabular}{|l|c|c|c|}
\hline Frequency category & Frequency range (yr-1) & \multicolumn{2}{|c|}{$\begin{array}{c}\text { Primary concentration } \\
\text { guidelines }\end{array}$} \\
\cline { 3 - 4 } & & Onsite & Offsite \\
\hline Anticipated & $>10^{-2}$ to $\leq 10^{0}$ & $\leq$ ERPG-1 & $\leq$ PEL-TWA \\
\hline Unlikely & $>10^{-4}$ to $\leq 10^{-2}$ & $\leq$ ERPG-2 & $\leq$ ERPG-1 \\
\hline Extremely Unlikely & $>10^{-6}$ to $\leq 10^{-4}$ & $\leq$ ERPG-3 & $\leq$ ERPG-2 \\
\hline
\end{tabular}

ERPG = Emergency Response Planning Guideline PEL-TWA = permissible exposure limit - time-weighted average 


\section{RPP-5555 REV 0}

\section{Additional criteria to guide control decisions are the following}

- Control preferences are as follows:

1. Controls that prevent the accident versus those that mitigate its consequences

2. Passive engineered versus active engineered controls

3. Engineered controls versus administrative controls

- Controls providing significant defense-in-depth are classified as safety SSCs or are elevated to a TSR control

- TSR controls are not developed for postulated accidents resulting in only environmental consequences

- SSCs are not classified safety-class or safety-significant solely for preventing or mitigating postulated accidents resulting in environmental consequences

\section{Other criteria that are important considerations in control decisions are listed below}

- Control reliability, availability, and maintainability

- Control effects on facility workers (i.e., increased radiation doses or toxicological exposures -ALARA issues)

- Control optimization and integration

- Control cost/benefit

- Control human factors impacts

- Control impacts on TWRS mission 
Attachment II

\section{CONTROL DECISION RECORD}

\section{HAZARD/ACCIDENT TITLE:}

Structures, Systems, and Components (SSCs)

\begin{tabular}{|l|c|c|c|c|}
\hline \multirow{2}{*}{$\begin{array}{c}\text { Structures, Systems, } \\
\text { and Components }\end{array}$} & \multicolumn{2}{|c|}{ Classification } & \multirow{2}{*}{ Safety Function } & Comments \\
\cline { 2 - 3 } & $\mathrm{SC}^{*}$ & SS* $^{*}$ & & \\
\hline & & & & \\
\hline & & & & \\
\hline & & & & \\
\hline
\end{tabular}

* SC is safety class

SS is safety significant

Technical Safety Requirements (TSRs)

\begin{tabular}{|c|c|c|}
\hline Control & Safety Function & Comments \\
\hline & & \\
\hline & & \\
\hline & & \\
\hline
\end{tabular}

\section{Defense-in-Depth Controls}

\begin{tabular}{|l|l|l|}
\hline Control & Safety Function & Comments \\
\hline & & \\
\hline & & \\
\hline & & \\
\hline
\end{tabular}


RPP-5555 REV 0

ATTACHMENT 5 - PART 4

PRESENTATIONS AT THE CONTROL DECISION MEETING ON APRIL 19, 2000 TO ADDRESS FLAMMABLE GAS HAZARDS IN WASTE TRANSFER SYSTEMS 


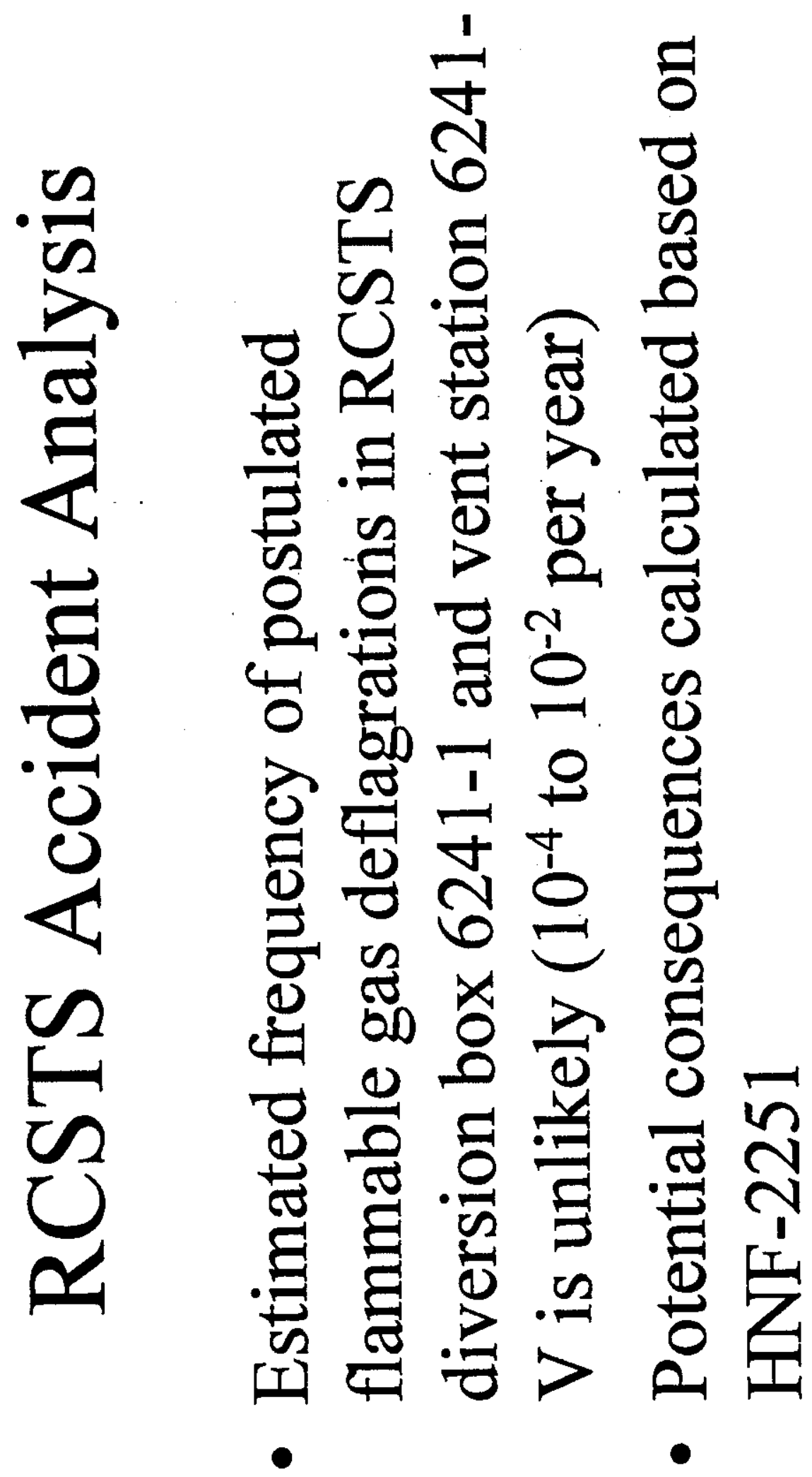


RPP-5555 REV 0

\section{Risk Assessment of Flammable Gas Hazards in RCSTS Diversion Box 6241-A and Vent Station 6241-V}

\begin{tabular}{|c|c|c|}
\hline & RCSTS Diversion Box 6241-A & RCSTS Vent Station 6241-V \\
\hline Size of the structure & $164,000 \mathrm{gal}$ & $54,700 \mathrm{gal}$ \\
\hline $\begin{array}{l}\text { Estimated frequency of a } \\
\text { postulated flammable gas } \\
\text { deflagration in the structure [i.e., } \\
\text { waste transfer leak into the } \\
\text { structure that results in the } \\
\text { buildup of flammable gas to the } \\
\text { lower flammability limit (LFL) } \\
\text { and an ignition source] }\end{array}$ & Unlikely & Unlikely \\
\hline $\begin{array}{l}\text { Offsite radiological risk } \\
\text { evaluation guideline (REG) }\end{array}$ & $0.5 \mathrm{rem}$ & $0.5 \mathrm{rem}$ \\
\hline $\begin{array}{l}\text { Waste leak [i.e., material at risk } \\
\text { (MAR)] required for a postulated } \\
\text { flammable gas deflagration in } \\
\text { the structure to equal the offsite } \\
\text { radiological REG }\end{array}$ & $225,000 \mathrm{gal}$ & $225,000 \mathrm{gal}$ \\
\hline $\begin{array}{l}\text { Can a postulated flammable gas } \\
\text { deflagration in the structure } \\
\text { challenge the offsite radiological } \\
\text { REG }\end{array}$ & No & No \\
\hline Offsite Toxicological REG & $\begin{array}{c}1 \\
\text { (ERPG-1) }\end{array}$ & $\begin{array}{c}1 \\
\text { (ERPG-1) }\end{array}$ \\
\hline $\begin{array}{l}\text { Waste leak (MAR) required for a } \\
\text { postulated flammable gas } \\
\text { deflagration in the structure to } \\
\text { equal the offsite toxicological } \\
\text { REG }\end{array}$ & $1,300,000 \mathrm{gal}$ & $1,300,000$ gal \\
\hline $\begin{array}{l}\text { Can a postulated flammable gas } \\
\text { deflagration in the structure } \\
\text { challenge the offsite } \\
\text { toxicological REG }\end{array}$ & No & No \\
\hline
\end{tabular}




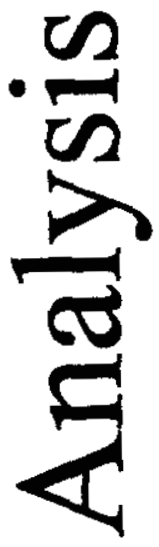

웅
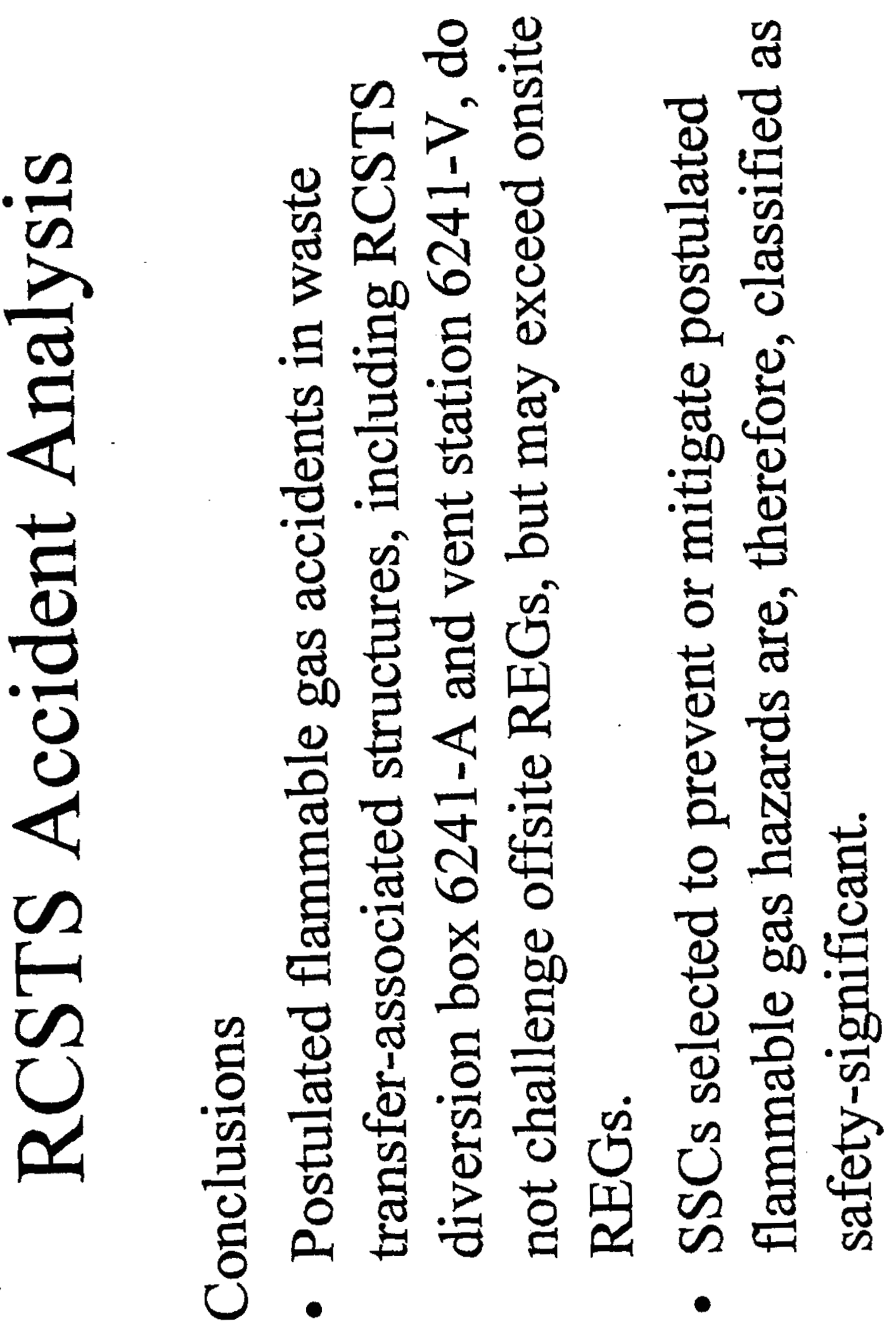

C

$E$ 


\section{DISTRIBUTION SHEET}

To

Distribution

Project Title/Work Order

RPP-5555, "Control Decisions for Elammable Gas Hazards in Waste Transfer Systems"

\section{Name}

D. G. Baide

R. J. Cash

L. A. Dominoske-Rauch

G. L. Johnsor:

P. F. Kisor

L. J. Kripps $(5$ Copies $)$

R. E. Larson

R. S. Nicholson

D. W. Reberger

D. Scott

C. J. Wi?..iams

Central Fi les (Original + 1 Copy)
From
NS \&L/CH2M HILL Hanford Group, Inc.

Text

MSIN

S5-0 5

R2-44

S5-13

R2-44

T4-07

R1-49

T 4-07

S5-05

$55-13$

\$5-07

R1-49

A.3-88
Page 1 of 1

Date

EDT No. 625125

ECN No. N/A With Alt With All Text Only Appendix Attach.

Only

EDT/ECN

Only 